\title{
The Solid-State Structures of Cyclic NH Carboximides
}

\author{
R. Alan Aitken *(i) and Dheirya K. Sonecha
}

EaStCHEM School of Chemistry, University of St Andrews, North Haugh, St Andrews, Fife KY16 9ST, UK

* Correspondence: raa@st-and.ac.uk; Tel.: +44-1334-463865

Received: 28 May 2020; Accepted: 9 July 2020; Published: 12 July 2020

\begin{abstract}
The patterns adopted in the solid state structures of over 300 cyclic NH carboximides as determined by X-ray diffraction are reviewed. While the analysis shows that the majority of these fit into just a few common patterns, a significant number exhibit more complex and interesting patterns involving the other functional groups present in addition to the cyclic imide.
\end{abstract}

Keywords: cyclic imide; X-ray structure; hydrogen bonding

\section{Introduction}

Cyclic $\mathrm{NH}$ carboximides containing the function $-\mathrm{C}(=\mathrm{O})-\mathrm{NH}-\mathrm{C}(=\mathrm{O})-$ are an important class of organic compounds whose physical properties, reactivity and applications have been thoroughly studied [1]. A recent monograph [2] includes detailed coverage of many aspects of their chemistry including synthesis, applications in biotechnology, catalysis, asymmetric synthesis, natural products, and agricultural and medicinal chemistry. Particularly in connection with the last topic, there has been sustained interest in thalidomide and structural analogues for a range of medicinal applications. However, as far as we are aware, there has so far been no systematic survey of the many structures of cyclic carboximides that have been determined by X-ray diffraction. The $\mathrm{NH}$ imides are of particular interest in this context since there is the opportunity for the $\mathrm{NH}$ and one or both $\mathrm{C}=\mathrm{O}$ groups to participate in intermolecular hydrogen bonding. In this review we aim to discuss the structures observed for all cyclic NH imides for which details were published as of late 2019. Among the structures found, many belong to just a few common types, whereas others display unique modes of hydrogen bonding. In our survey we have excluded structures involving coordination to metals, coordination to solvents, and extremely complex bonding patterns. The remaining examples, totalling just over 300 structures, are considered in order of increasing ring size with further classification, for the most common five- and six-membered ring systems, according to degree of unsaturation and substitution pattern.

\section{Methodology and Main Hydrogen Bonding Patterns}

The Cambridge Structural Database (CSD) was searched using the structural fragment $\mathrm{CO}-\mathrm{NH}-\mathrm{CO}$ in October 2019 and the resulting cyclic compounds were screened to remove entries involving metal complexes and salts, hydrogen-bonding to solvent molecules, and extremely complex hydrogen-bonding patterns. The remaining 311 structures are surveyed according to ring size and substituent pattern and the observed structure types are discussed. The structures are shown with their CSD reference codes and with the atoms involved in hydrogen bonding highlighted in colour, with red for the primary interaction (normally starting from imide $\mathrm{NH}$ ) and further interactions then coloured blue, green, etc. A total of 16 structures which have been deposited in the Cambridge Database do not have corresponding journal publications and these are referred to as "CSD Communication" with the Reference Code. 
A total of eight general patterns of hydrogen bonding were identified and these are illustrated using a generalised succinic anhydride molecule (Figures 1 and 2). Two hydrogen bonding patterns emerge as by far the commonest, together accounting for 193 of the reported structures. These are a simple centrosymmetric dimer (pattern A, 119 examples) and a ribbon with two rows of molecules connected by hydrogen bonding (pattern B, 74 examples). Somewhat less common, but still important, are structures involving an intermolecular hydrogen bonding interaction of the imide $\mathrm{NH}$ with a remote hydrogen bond acceptor. Thus we can have dimers formed by interaction of $\mathrm{NH}$ with a remote nitrogen atom (pattern C, 2 examples) or a remote oxygen atom (pattern D, 9 examples) and also, simple linear chains of molecules formed by $\mathrm{NH}$ hydrogen bonding to remote nitrogen (pattern $\mathrm{E}$, 11 examples) or remote oxygen (pattern F, 29 examples).<smiles>[X]C1CC(=O)N2C(=O)CC([X])N2C1=O</smiles>

Dimer A<smiles>O=C1CC2CCCCCCCCCNCNC(=O)C(C2)C1=O</smiles>

Imide $\mathrm{NH}$ to remote $\mathbf{N}$ dimer $\mathbf{C}$<smiles>O=C1CCOCCCCCCC2C(=O)NCOCCCCCCC(C1)C2=O</smiles>

Imide $\mathrm{NH}$ to remote $\mathbf{O}$ dimer $\mathbf{D}$<smiles>[X]C1CC(=O)N(CC)C1=O</smiles>

Ribbon B<smiles>N#C[C@H]1CC(=O)N[C@@H]1N=C[C@@H]1CC(=O)NC1=O</smiles>

Simple chain with remote nitrogen $\mathbf{E}$

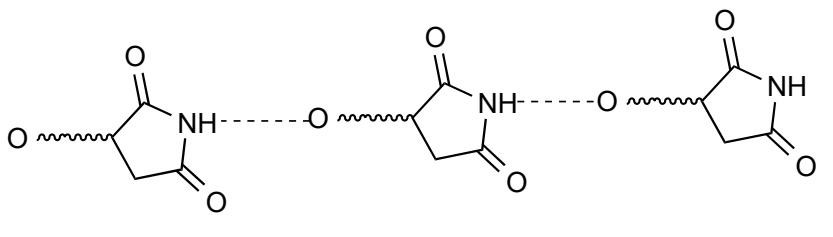

Simple chain with remote oxygen $\mathbf{F}$

Figure 1. The most commonly observed hydrogen bonding patterns.

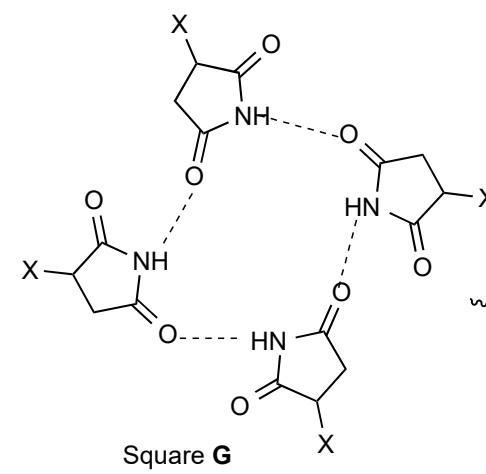

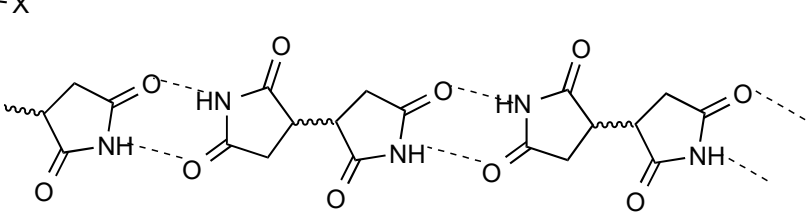

Figure 2. Less common hydrogen bonding patterns. 
There are a few less common patterns of hydrogen bonding which do nonetheless occur several times. Four molecules may hydrogen bond in a square array (pattern G, 2 examples). For bis imides the simple dimer form $\mathbf{A}$ translates to a doubly linked chain (pattern $\mathbf{H}, 11$ examples).

Particularly in analysing some of the more complex patterns observed, the "graph set" analysis introduced by Etter and Bernstein [3-5], may be useful and the observed pattern is also analysed using that system in many cases. The hydrogen bonding patterns $\mathbf{A}-\mathbf{H}$ would be described in that system as follows: $\mathbf{A}=R^{2}{ }_{2}(8), \mathbf{B}=C(4), \mathbf{C}=\mathbf{D}=R^{2}{ }_{2}(\mathrm{n}), \mathbf{E}=\mathbf{F}=C(\mathrm{n}), \mathbf{G}=R^{4}{ }_{4}(16), \mathbf{H}=C^{2}{ }_{2}(\mathrm{n})\left[R^{2}{ }_{2}(8)\right]$. It is interesting to note that these designations are valid regardless of the ring size of the cyclic imide.

\section{Maleimides}

\subsection{Maleimide and Monosubstituted Maleimides}

Two separate structures have been published for the parent maleimide 1 [6,7] (Figure 3), both of which involve hydrogen-bonded dimers A. Among the three monosubstituted maleimide structures located two, compounds 2 [8] and 3 [9] (Figure 3), involve a linear hydrogen-bonded ribbon structure $\mathbf{B}$. The remaining compound 4 [10] involves a more complex pattern in which each imide NH is hydrogen bonded to the acetyl $\mathrm{CO}$ forming the link between chains of molecules joined by bonding of one of the imide carbonyls to the acetylamino $\mathrm{NH}$ (Figure 4). In graph set notation $C(7)$ chains of category $\mathbf{F}$ combine with $C(6)$ to give $R_{4}^{4}(21)$.

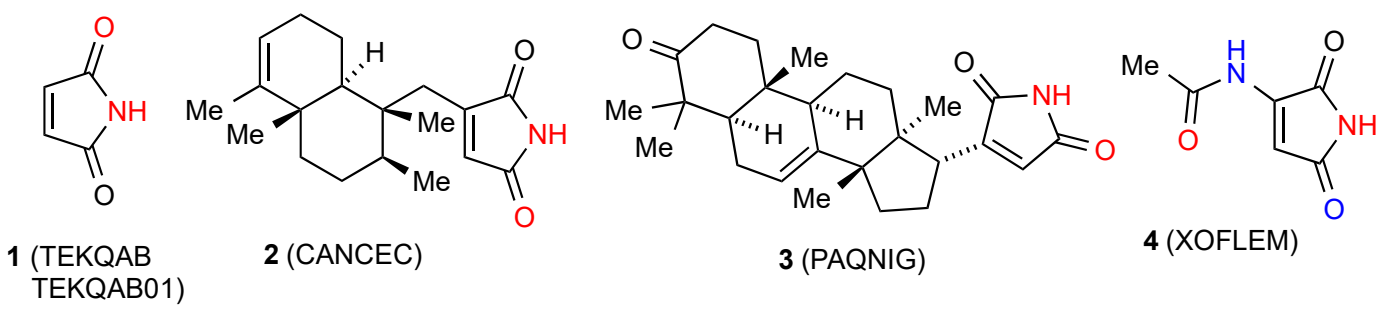

Figure 3. Maleimide and monosubstituted maleimides.<smiles>COC(=O)NC1=CC(=O)N(C)C1=O</smiles>

Figure 4. Structure observed for compound 4 . 


\subsection{3,4-Disubstituted Maleimides}

Of the 273 ,4-disubstituted maleimide structures located, the most commonly observed pattern is the hydrogen-bonded dimer $\mathbf{A}$. The 13 structures noted as exhibiting the dimeric $R^{2}{ }_{2}(8)$ bonding pattern are made up of both symmetrical (where the substituents on the ring are the same) compounds $\mathbf{5}$ [11,12], $\mathbf{6}$ [12], 7 [12], 8 [13], 9 [14,15], 10 [16] and $\mathbf{1 1}$ [17] and unsymmetrical examples 12 [18], $\mathbf{1 3}[19,20]$ and $\mathbf{1 4}$ [21] (Figure 5).<smiles>[R]C1=C([R])C(=O)NC1=O</smiles><smiles>[R]n1cc(C2=C(c3cn([R])c4ccccc34)C(=O)NC2=O)c2ccccc21</smiles>

$5 \mathrm{R}=4-\mathrm{MeOC}_{6} \mathrm{H}_{4}($ ZAPGAA, ZAPGAA01)

$6 \mathrm{R}=4-\mathrm{FC}_{6} \mathrm{H}_{4}(\mathrm{PAVBEW})$

$7 \mathrm{R}=4-\mathrm{MeC}_{6} \mathrm{H}_{4}$ (PAVBAS)

$8 \mathrm{R}=$ ferrocenyl (OWOPAS)

$9 \mathrm{R}=$ 2-thienyl (FOMVIO, FOMVIO01, FOMVIO02)

$10 \mathrm{R}=\mathrm{n}-\mathrm{C}_{12} \mathrm{H}_{25}$ (LUWHES)

$11 \mathrm{R}=\mathrm{CH}_{2} \mathrm{C} \equiv \mathrm{CH}$ (IGATIV)<smiles>[R]C1=C([R])C(=O)NC1=O</smiles>

$12 \mathrm{R}^{1}=3-\mathrm{MeOC}_{6} \mathrm{H}_{4}, \mathrm{R}^{2}=\mathrm{CH}_{2} \mathrm{Ph}$ (GUSHEI)

$13 \mathrm{R}^{1}=\mathrm{SMe}, \mathrm{R}^{2}=\mathrm{Ph}(\mathrm{COXVUI})$<smiles>CC(C)=CCOc1ccc(C2=C(CC(C)C)C(=O)NC2=O)cc1</smiles>

Figure 5. Disubstituted maleimides forming dimers A.

Eight of the located structures, compounds 15 [22], 16 [22], 17 [23], 18 [18], 19 [24] and 20 [25] (Figure 6), display a linear hydrogen-bonded ribbon pattern B. It would seem that the presence of smaller substituents favours this structure whereas larger substituents more commonly lead to the dimeric pattern $\mathbf{A}$.<smiles>[R]C1=C([R])C(=O)NC1=O</smiles>

$15 \mathrm{R}=\mathrm{Br}(\mathrm{IRUDIJ})$

$16 \mathrm{R}=\mathrm{Cl}($ IRUFEH, IRUFEH01)

$17 \mathrm{R}=\mathrm{Et}(\mathrm{LICHEL})$<smiles>[R]C1=C([R])C(=O)NC1=O</smiles>

$18 \mathrm{R}^{1}=\mathrm{Me}, \mathrm{R}^{2}=\mathrm{CH}_{2} \mathrm{Ph}$ (GUSHIM,GUSHAE)

$19 \mathrm{R}^{1}=3$-indolyl, $\mathrm{R}^{2}=\mathrm{Br}(\mathrm{VAWFEF})$<smiles>O=C1NC(=O)C2=C1C(=O)c1cccc3cccc2c13</smiles>

20 (JOXYEC)

Figure 6. Disubstituted maleimides forming ribbon pattern B.

Three structures, 21, 22 [26] and 23 [27] (Figure 7) show a linear chain where the NH of the imides is hydrogen-bonded to a remote ester or ether oxygen (pattern $\mathbf{F}$ or $C(8)$ ). In the case of compound 23 there is an additional $\mathrm{C}(11)$ interaction between the phenolic $\mathrm{OH}$ and a further ether oxygen leading to cross-linking of the chains. Compound 24 [28] forms a linear chain with the imide NH bonded to the remote pyridine nitrogen (pattern $\mathbf{E}$ or $C(9)$ ) and additionally, an intramolecular $(S(6)$ ) hydrogen bond between the 2-NH on the pyridyl ring and the amide oxygen. 
<smiles>[R]C(=O)OCC1=C(c2cccc(C)c2)C(=O)NC1=O</smiles>

$21 \mathrm{R}=\mathrm{Me}(\mathrm{VAQKIJ})$

$22 \mathrm{R}=\mathrm{Et}(\mathrm{VAQKEF})$<smiles>COc1ccc(C2=C(c3cc(OC)c(OC)c(OC)c3)C(=O)NC2=O)cc1O</smiles>

23 (FOGTEB)<smiles>COC(=O)c1cccnc1NC1=C(NC2CC2)C(=O)NC1=O</smiles>

24 (MUDNUW)

Figure 7. Disubstituted maleimides showing $\mathrm{NH}$ bonding to remote $\mathrm{O}$ or $\mathrm{N}$ acceptors.

The two remaining structures in this category exhibit more complex patterns of hydrogen bonding. In compound 25 [29] (Figure 8) the ribbon structure of pattern $\mathbf{B}$ is further reinforced by $\mathrm{OH}$ to $\mathrm{P}=\mathrm{O}$ hydrogen bonding. This basic pattern can be described as $C(4)$ combining with $C(7)$ to give $R_{3}^{3}{ }_{3}(16)$. Additional interactions between the $\mathrm{P}-\mathrm{OH}$ group and the $\mathrm{P}=\mathrm{O}$ of an adjacent ribbon make for a complex overall structure.<smiles>C[R](=O)([O-])CC1=C(O)C(=O)NC1=O</smiles>

25 (VOWGAP)

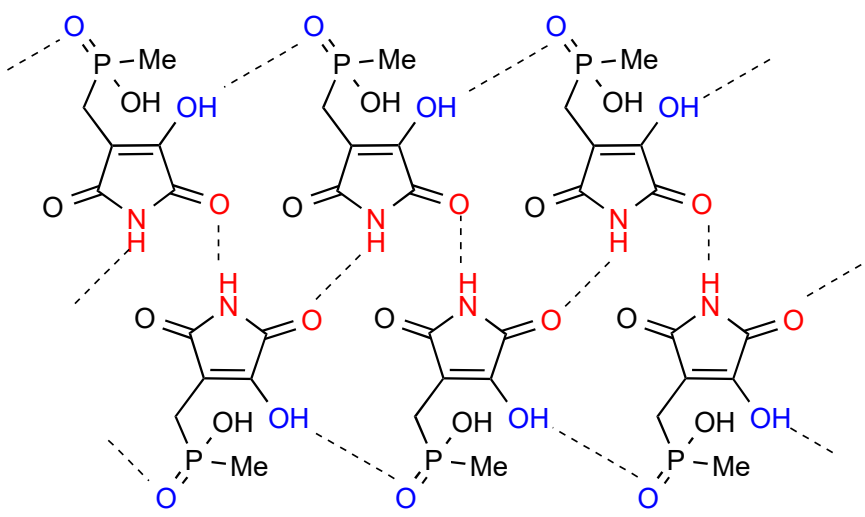

Figure 8. Structure observed for compound 25.

The Hydrogen-bonding pattern of compound 26 [30,31] (Figure 9) involves parallel rows of molecules in which there is a $C(8)$ interaction between imide $\mathrm{NH}$ and $\mathrm{OMe}$ at the 3-position of the 3,4,5-trimethoxyphenyl substituent. These are then cross-linked by additional $C(11)$ bonding between the OMe at the 4-position and the indole $\mathrm{NH}$ giving a 2-dimensional array containing $R_{4}^{4}(31)$ units.<smiles>COc1cc(C2=C(c3c[nH]c4ccccc34)C(=O)NC2=O)cc(OC)c1OC</smiles>

Figure 9. Structure observed for compound 26. 


\subsection{Ring-Fused Maleimides}

Of the five structures located for ring fused maleimides, two, compounds 27 [32] and 28 [33] (Figure 10), form a linear ribbon of pattern B. The other compounds all form more complex patterns involving groups other than the imide in hydrogen bonding. Compound 29 [34] forms a ribbon structure in which the $\mathrm{NH}$ of the imide and the $\mathrm{CO}$ away from the $\mathrm{NH}$ of the seven-membered ring form a simple $R^{2}{ }_{2}(8)$ dimer. These dimer units are then connected to each other by the supplemental $C(8)$ interaction of the other imide $\mathrm{CO}$ with the indole $\mathrm{NH}$ of the next unit to give the pattern shown which contains $R^{4}{ }_{4}(22)$ units (Figure 10).

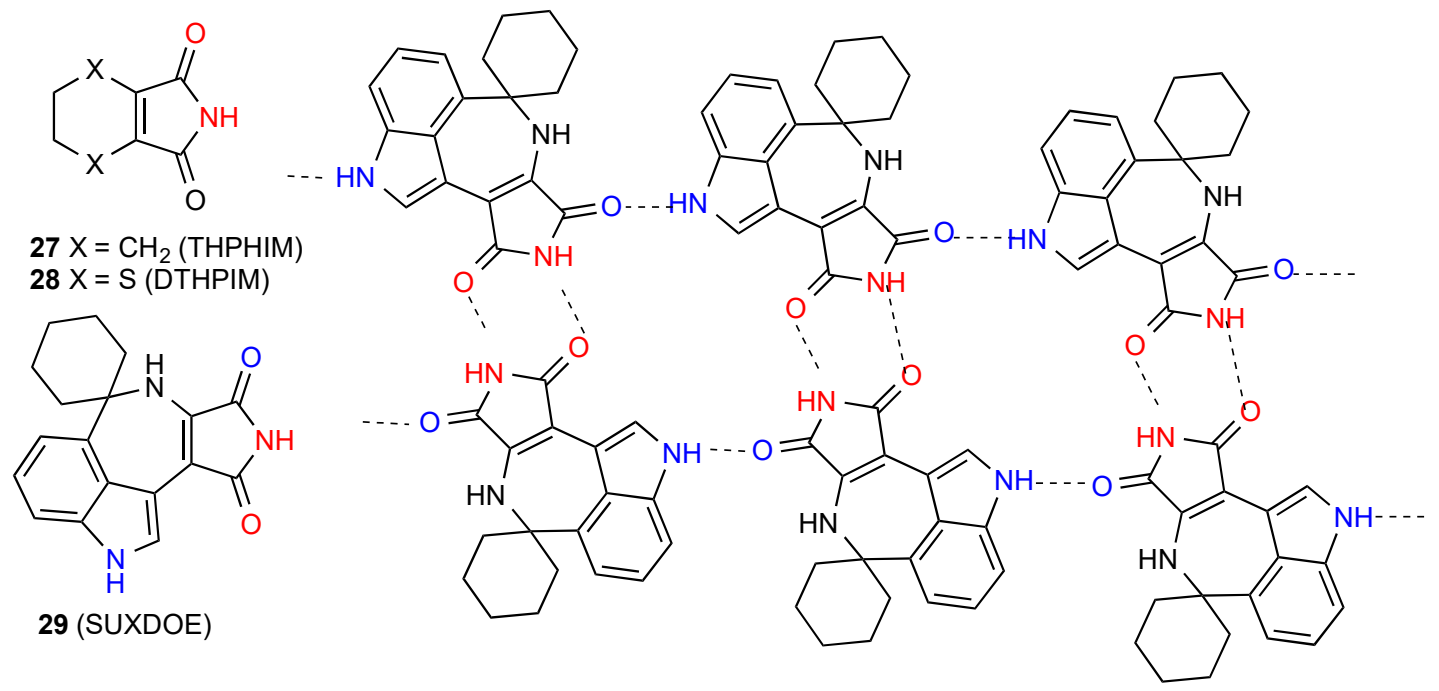

Figure 10. Structures of ring-fused maleimides 27-29.

Compound 30 forms $\mathrm{C}(8)$ chains by interaction of the imide $\mathrm{NH}$ with the remote ester carbonyl oxygen and these are cross-linked by the ring $\mathrm{NH}$ to nitro group $C(10)$ interaction resulting in a two-dimensional network containing $R_{4}^{4}(31)$ units (Figure 11) [35].<smiles>CC1=C(C(=O)OC(C)C)C(c2cccc([N+](=O)[O-])c2)C2=C(N1)C(=O)NC2=O</smiles>

30 (ELIHUC)<smiles>CCOC(=O)C1=C(C(=O)OC)NC2=C(C(=O)NC(=O)C2C)C1c1cccc([N+](=O)[O-])c1</smiles>

Figure 11. Structure adopted by compound 30.

Compound 31 forms dimers of pattern $\mathbf{A}$ by imide $\mathrm{NH}$ to $\mathrm{CO}$ interaction and these are then further linked in a zig-zag arrangement by dimer formation between the other imide $\mathrm{CO}$ and the six-membered ring $\mathrm{NH}$ (Figure 12) [36]. This gives an overall designation of $C(10)\left[R^{2}{ }_{2}(8), R^{2}{ }_{2}(10)\right]$. 
<smiles>O=C1NC(=O)C2=C1NCCS2</smiles>

31 (MERXUF)

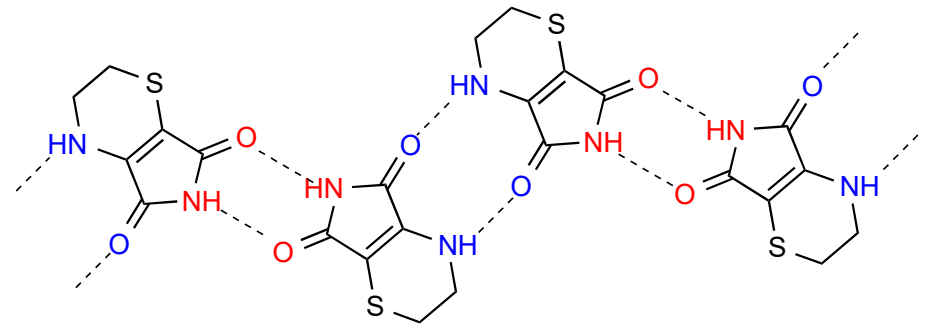

Figure 12. Structure adopted by compound 31.

\section{Succinimides}

\subsection{Succinimide}

Two separate structures have been published for the parent succinimide 32 [37,38] (Figure 13), both of which involve hydrogen-bonded dimers $\mathbf{A}$.<smiles>O=C1CCC(=O)N1</smiles>

35 (PHPYRO)<smiles>O=C1CC(Nc2ccccc2)C(=O)N1</smiles>

33 (PHAMPD)<smiles>O=C1CC(c2cccc([N+](=O)[O-])c2)C(=O)N1</smiles>

36 (TANPUT)<smiles>CCOc1ccc(C2CC(=O)NC2=O)cc1Br</smiles>

37 (BEPSCM)<smiles>O=C1CC(C2c3ccccc3-c3ccccc32)C(=O)N1</smiles>

34 (DOBFUX)

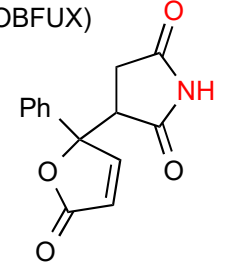

38 (IRONIO)

Figure 13. Succinimide and monosubstituted succinimides exhibiting patterns $\mathbf{A}$ and $\mathbf{B}$.

\subsection{Monosubstituted Succinimides}

Two of the twelve structures located for monosubstituted succinimides, compounds 33 [39] (Figure 13) and 34 [40] exist as simple hydrogen-bonded dimers A. A further four compounds: 35 [41], 36 [42], 37 [43] and 38 [44] show linear hydrogen-bonded ribbons of type $\mathbf{B}$. It is interesting to note the variation among these examples in whether it is the carbonyl nearer or more remote from the substituent that is involved in bonding.

In compounds 39 [45] and 40 [46] (Figure 14) the $\mathrm{NH}$ of the imide is linearly bonded to a remote heterocyclic nitrogen in the next molecule (pattern E, $C(10)$ and $C(7)$, respectively). One reported structure, the compound 41 [47], forms linear $C(7)$ chains with the $\mathrm{NH}$ of the imide interacting with a remote ketone oxygen on the next molecule (pattern $\mathbf{F}$ ).

The three remaining structures all exhibit distinct and more complex patterns of hydrogen bonding. In compound 42 [48] (Figure 15) the imide $\mathrm{NH}$ bonds to the oxygen atom of the acyclic secondary alcohol group of another molecule $(C(6))$, with the hydrogen atom of that alcohol further bonding $(C(8))$ to the ring secondary alcohol in a third molecule. Since each molecule has two donor sites and two acceptor sites, the end result is a complex three-dimensional network.

In compound 43 [49] (Figure 16) two parallel chains of molecules are hydrogen bonded to each other in a $C(4)$ fashion or pattern B. Additionally, the other imide CO of the molecule links with the $\mathrm{OH}$ on the pyrrole ring of the next molecule in a $C(8)$ chain, leading to formation of $R^{3}{ }_{3}(17)$ units. 
<smiles>O=C1CC(NCc2ccncc2)C(=O)N1</smiles>

39 (CAYPUN)<smiles>O=C1CC(n2nnc3ccccc32)C(=O)N1</smiles>

40 (BUVGEG)<smiles>O=C1CC(C2(C(=O)c3ccccc3)C(=O)C(=O)C2c2ccccc2)C(=O)N1</smiles>

41 (AYUDEF)

Figure 14. Monosubstituted succinimides exhibiting patterns E and F.

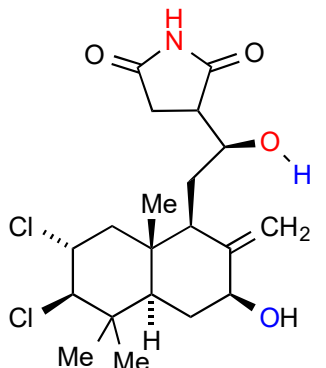

42 (REWWOF)

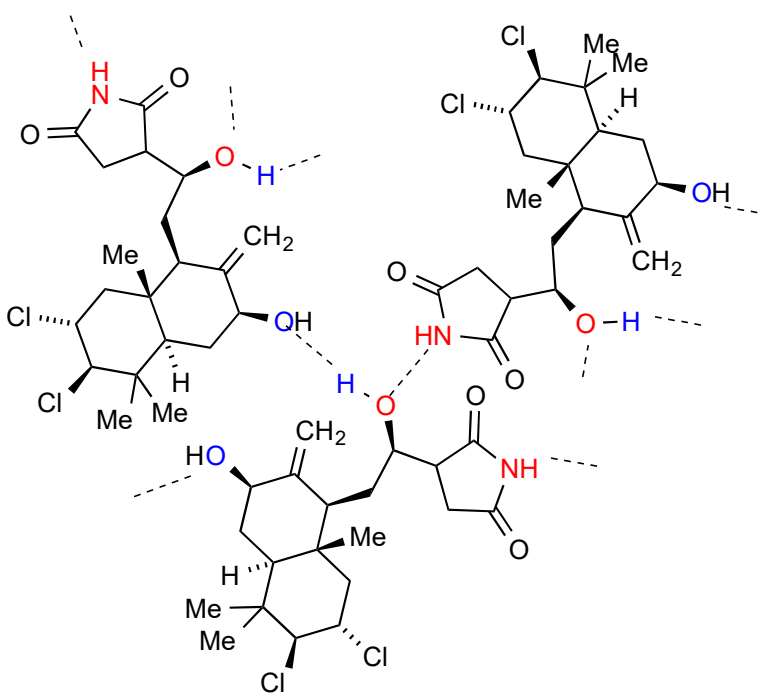

Figure 15. Structure observed for compound 42.<smiles>O=Cc1ccc(CO)n1C1CC(=O)NC1=O</smiles>

43 (JOCLOE)

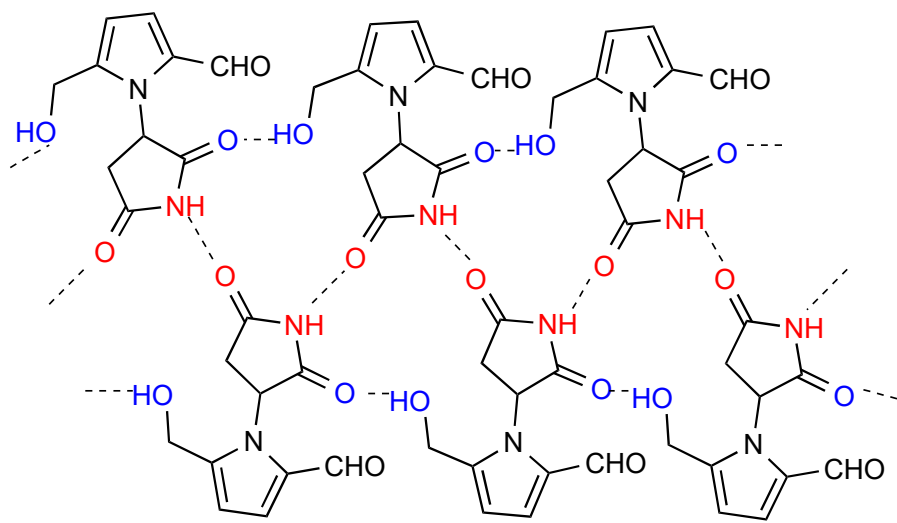

Figure 16. Structure observed for compound 43.

Compound 44 [50] (Figure 17) has a complex hydrogen-bonding system with no fewer than four separate interactions which leads to a two-dimensional network. The molecules are arranged in $C(13)$ chains linked both by bonding between the imide $\mathrm{NH}$ and the 3-N of adenine and between the $\mathrm{CO}$ of the same imide and one $\mathrm{NH}$ of the adenine 4 -amino substituent forming $R^{2}{ }_{2}(8)$ units. Cross-linking between the chains is also observed with $C(6)$ interactions between the other $\mathrm{NH}$ of the 4-amino substituent and 1-N of adenine and $C(4)$ between an amide carbonyl of one chain and the amide $\mathrm{NH}$ of the next. 


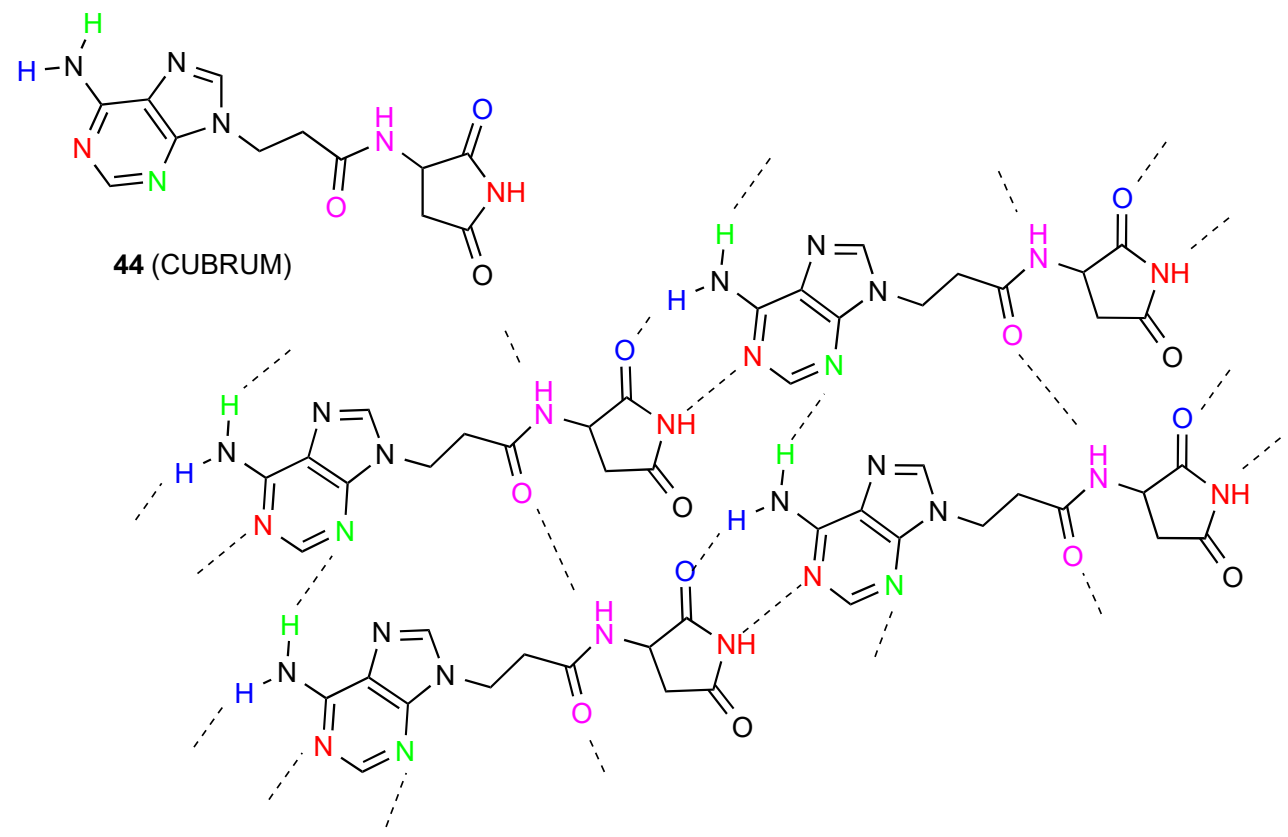

Figure 17. Structure observed for compound 44.

\subsection{3,3-Disubstituted Succinimides}

Eleven structures were located for 3,3-disubstituted succinimides. Two of these structures, compounds 45 [51] and 46 [52] (Figure 18) show simple dimer hydrogen-bonding of pattern A. Five reported structures of three compounds: racemic 47 [53], (S)-48 [53] and (R)-49 [53] exhibit linear ribbon type hydrogen-bonding (pattern $B$ ). It is again interesting to note that the carbonyl nearer the substituent is involved in the former cases whereas in the latter, it is the one away from the substituents.<smiles>O=C1C/C(=C\c2ccccc2)C(=O)N1</smiles>

45 (ENIFUE)<smiles>CCC1(CC)CC(=O)NC1=O</smiles>

46 (EMOZOX)<smiles>CC1(c2ccccc2)CC(=O)NC1=O</smiles>

47 (VOQJES)<smiles>C[C@]1(c2ccccc2)CC(=O)NC1=O</smiles>

48 (VOQHOA,<smiles></smiles>

49 (VOQHIU, VOQHIU01)

Figure 18. 3,3-Disubstituted succinimides with patterns A and B.

Three reported structures of compounds 50 [54], 51 [54] and 52 [55] (Figure 19) show linearly hydrogen-bonded $\mathrm{C}(8)$ chains with the $\mathrm{NH}$ of the succinimimide bonded to the more remote of the two six-membered ring imide $\mathrm{CO}$ in pattern $\mathbf{F}$. The remaining structure, compound 53 [56] involves a linear $\mathrm{C}(6)$ chain of type $\mathbf{E}$ with the $\mathrm{NH}$ of the imide bonded to the remote pyrrolidine nitrogen of the next molecule with an additional intramolecular $S(6)$ interaction of the imide $\mathrm{CO}$ and the pyrrolidine NH as shown.<smiles>[R]c1ccc2c(c1)C1(CC(=O)NC1=O)C(=O)N2Cc1ccc(Br)cc1F</smiles>

$50 \mathrm{R}=\mathrm{H}$ (HEMVEA) $51 \mathrm{R}=\mathrm{F}$ (HEMVIE)<smiles>O=C1CC2(C(=O)N1)C(=O)N(Cc1ccc(Br)cc1F)C(=O)c1cccn12</smiles>

52 (GOPFAS)<smiles>COC(=O)[C@H]1[C@H]2c3ccccc3C1(c1ccc(Br)cc1)[C@@H]2c1ccccc1</smiles>

53 (TUDJIN)

Figure 19. 3,3-Disubstituted succinimides with patterns $\mathbf{E}$ and $\mathbf{F}$. 


\subsection{3,4-Disubstituted Succinimides}

Of the nine structures located for 3,4-disubstituted succinimides, five structures viz. compounds $\mathbf{5 4}$ [57], 55 [58], $\mathbf{5 6}$ [58], 57 [59] and $\mathbf{5 8}$ [59] (Figure 20) exist as hydrogen-bonded dimers, pattern A. Two reported structures of compound $59[60,61]$ exhibit linear ribbons of pattern B.<smiles>COc1ccccc1[C@H]1C(=O)NC(=O)[C@H]1c1cn(Cc2ccccc2)c2ccccc12</smiles>

54 (SUXCIY)<smiles>CCO[C@@H](c1ccc(OC)cc1)[C@H]1C(=O)NC(=O)[C@@H]1C</smiles>

58 (IHABEY)<smiles>CO[C@@H](C)[C@H]1C(=O)NC(=O)[C@H]1C</smiles>

55 (MOPRDB10) 56 (MOPRDA10)<smiles>CCOC(=O)[C@H]1C(=O)NC(=O)[C@H]1c1ccccc1</smiles>

59 (CEXZEK, CEXZEK10)

Figure 20. 3,4-Disubstituted succinimides with patterns A and B.

Compound 60 [62] (Figure 21) exhibits type $\mathbf{F}$ hydrogen bonding with the imide NH-bonded to the remote ester $\mathrm{CO}$ in a single linear $C(15)$ chain. The remaining compound $\mathbf{6 1}$ [63] exhibits a rare double-hydrogen-bonded ribbon pattern with two parallel rows and each imide NH bonded equally to the $\mathrm{CO}$ of two different molecules to give a $C^{2}{ }_{1}(4)\left[R^{2}{ }_{2}(8)\right]$ pattern. It is notable that within this racemic compound the molecules are arranged in complementary rows consisting each of a single enantiomer.
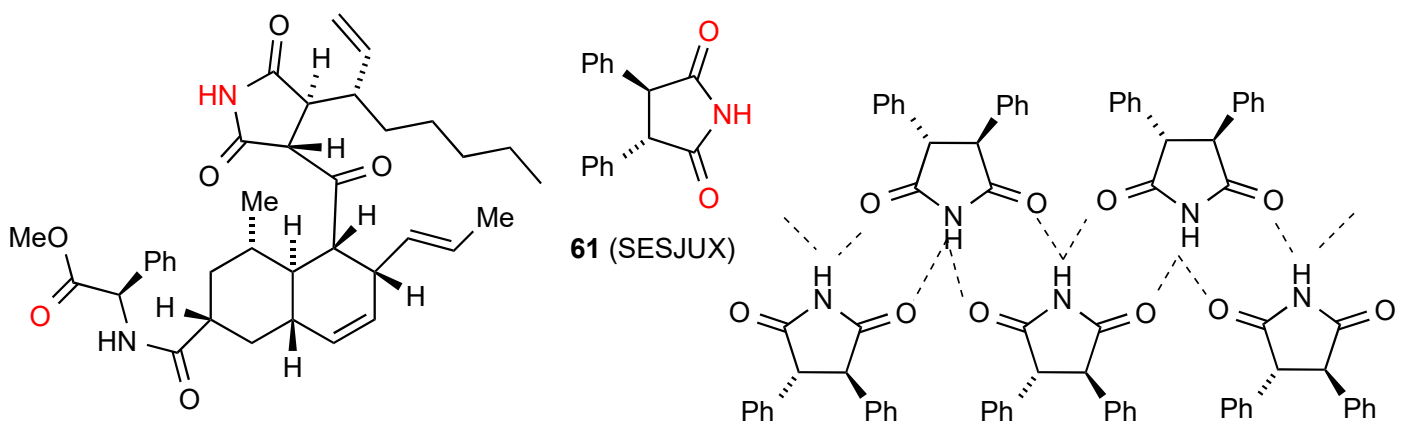

60 (GEBWES)

Figure 21. Structures of other 3,4-disubstituted succinimides.

\subsection{Tri- and Tetra-Substituted Succinimides}

Five structures have been located for tri- and tetra-substituted succinimides. Three of these structures, compounds 62 [64], 63 [65] and 64 [66] (Figure 22) exist as simple hydrogen-bonded dimers, pattern A. Compound 65 [67] forms a ribbon structure of type B.

The remaining compound $66[19,20]$ (Figure 23) has a more complex linkage. Two molecules dimerise, with imide $\mathrm{NH}$ and $\mathrm{CO}$ (methylthio side) interacting. The dimers are further linked to each other by the other imide $\mathrm{CO}$ bonding to the $\mathrm{OH}$ of another dimer. As for compound 31 this has designation $C(10)\left[R^{2}{ }_{2}(8), R^{2}{ }_{2}(10)\right]$. The compound is racemic and the enantiomers alternate within the structure as shown. 
<smiles>CC1C(=O)NC(=O)[C@]1(C)c1ccc(Cl)cc1</smiles>

62 (CPMCSI)

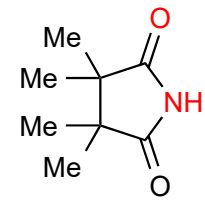

63 (YUFNES)<smiles>CC(C)=C1C(=O)NC(=O)C1=C(C)c1c(-c2ccccc2)n(C)c2ccccc12</smiles>

64 (IFOLUN)<smiles>O=C(CC1C(=O)NC(=O)C12CCCc1cc3c(nc12)CCCC3)Nc1ccccc1[N+](=O)[O-]</smiles>

65 (UQELOT)

Figure 22. Tri- and tetra-substituted succinimides with patterns $\mathbf{A}$ and $\mathbf{B}$.<smiles>CC1(C)C(=O)NC(=O)[C@@]1(O)c1ccccc1</smiles>

66 (COXVOC)

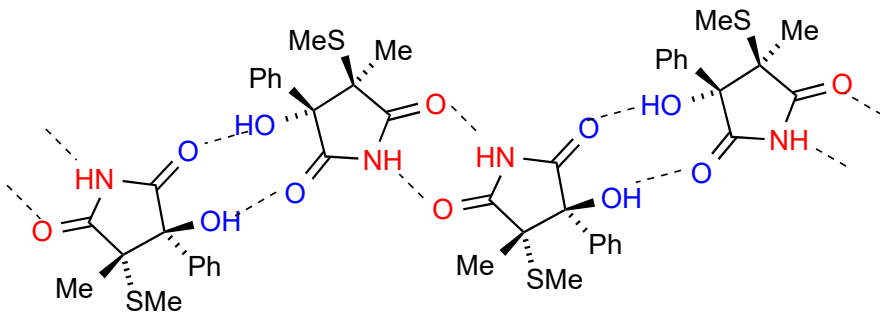

Figure 23. Structure adopted by compound 66 .

\subsection{Succinimides Fused to Three-Membered Rings}

Among the three reported structures for succinimides fused with three-membered rings, compound 67 [68] (Figure 24) shows no hydrogen bonding probably due to the high degree of steric hindrance. Compound 68 [69] exists in a ribbon, pattern B. The remaining compound 69 [70] exhibits $C(6)$ chains with the imide $\mathrm{NH}$ linked to the remote nitrogen of the $\mathrm{CN}$ substituent in the form of pattern $\mathbf{E}$.<smiles>C[C@@]12C(=O)NC(=O)[C@@]1(C#N)[C@]2(C)c1ccccc1</smiles>

67 (GIHPOE)<smiles>C[C@]12C[C@H]1C(=O)NC2=O</smiles>

68 (EACLEZ)<smiles>CC1=NN(c2ccccc2)C(=O)[C@]12C(C)(C)[C@]1(C)C(=O)NC(=O)[C@@]12C</smiles>

69 (NIXPAL)

Figure 24. Structures of succinimides fused to three-membered rings.

\subsection{Succinimides Fused to Four-Membered Rings}

Of the seven reported structures for succinimides fused to four-membered rings, compound $\mathbf{7 0}$ [71] (Figure 25) exists as a linear hydrogen-bonded ribbon of type B. Compound 71 [72] exists as a square of four molecules in the rather uncommon pattern $\mathrm{G}\left(\mathrm{R}_{4}^{4}(16)\right)$. The compound 72 [73] exhibits a linear $C(8)$ chain pattern $\mathbf{F}$ where the imide $\mathrm{NH}$ is bonded to the remote $\mathrm{CO}$ of the cyclohexenone ring. Two structures, compounds 73 [73] and 74 [74] exist as dimers of category $\mathbf{D}\left(R^{2}{ }_{2}(16)\right.$ and $R^{2}{ }_{2}(12)$, respectively) where the $\mathrm{NH}$ of the imide is bonded to the remote $\mathrm{O}$ of the other molecule.

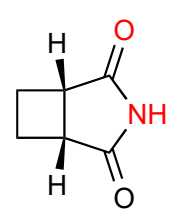

70 (LEHQIZ)<smiles>O=C1NC(=O)[C@@]2(Cl)[C@@H]3CCC=C[C@@H]3[C@]12Cl</smiles>

71 (COHTAU)

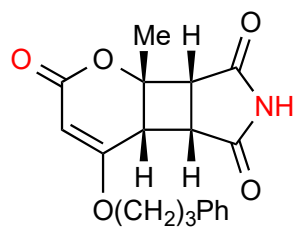

72 (QUBRAG)<smiles>[M]C12OC(=O)C=C(OCc3ccccc3)C1([2H])[C@H]1C(=O)NC(=O)[C@H]12</smiles>

73 (QUBQUZ)

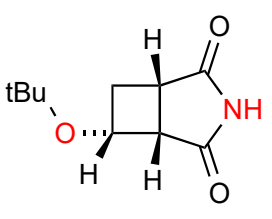

74 (QEPLUV)

Figure 25. Cyclobutane-fused succinimides showing common bonding patterns. 
The two remaining structures exhibit more complex patterns of hydrogen bonding. Compound 75 [75] (Figure 26) forms a ribbon structure of pattern B, with the imide NH and the $\mathrm{CO}$ (away from the isopropyloxy substituent) interacting. Additionally, the $\mathrm{NH}$ and $\mathrm{CO}$ of the six-membered rings link to the corresponding groups on adjacent ribbons creating a two-dimensional network with the combination of the two $C(4)$ interactions forming $R_{4}^{4}(23)$ units.
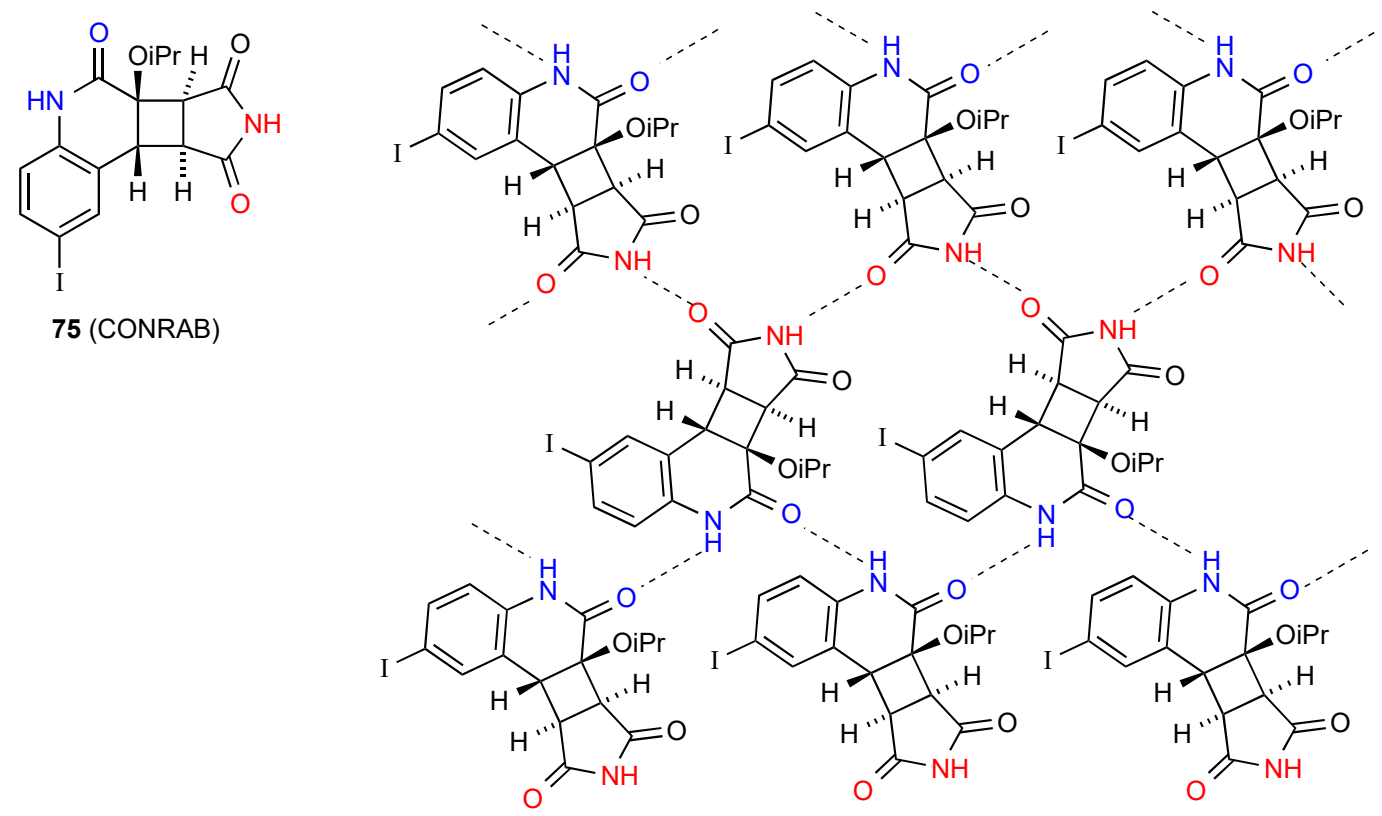

Figure 26. Structure adopted by compound 75 .

Compound 76 [73] (Figure 27) shows two linear antiparallel chains where each imide NH is bonded to the $\mathrm{CO}$ both of the pyranone ring of the next molecule in the same chain and to the one opposite in the other chain. Likewise, each pyranone $\mathrm{CO}$ is bonded to two imine $\mathrm{NH}$ groups, one in the same chain and one opposite to give a series of four-membered ring interactions holding the chains together. This pattern can be designated as $C(8) R^{2}{ }_{2}(6)$ giving rise also to $R^{2}{ }_{2}(16)$. There are no hydrogen-bonding interactions with the imide carbonyl groups.
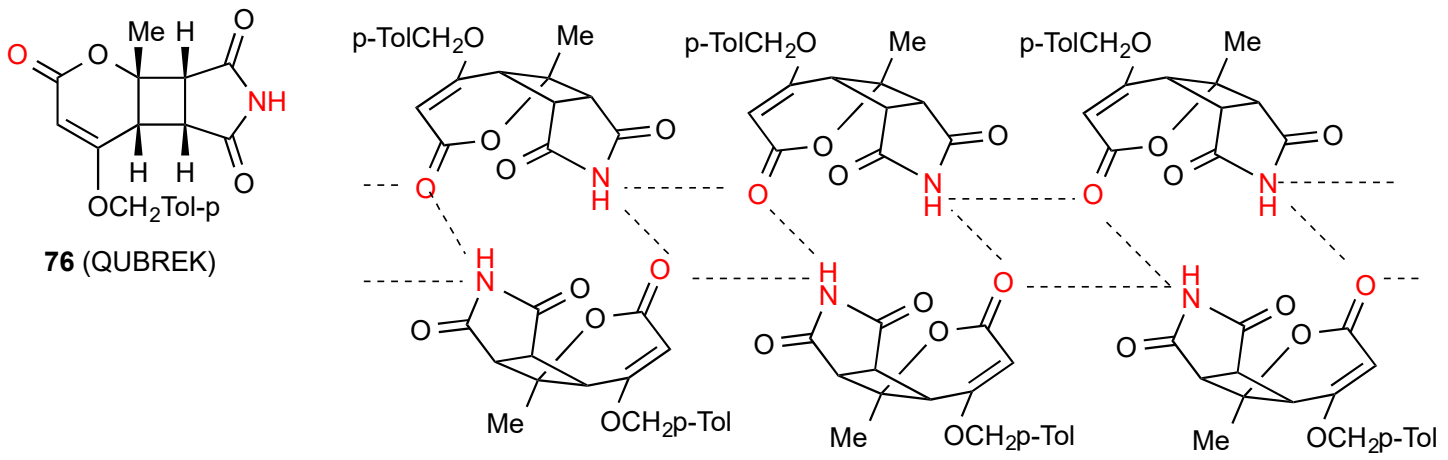

Figure 27. Structure adopted by compound $\mathbf{7 6 .}$

\subsection{Succinimides Fused to Five-Membered Rings}

Fifteen structures have been reported for succinimides fused to five-membered rings. Two of these, compounds 77 [76] and 78 [77] (Figure 28) exist as simple dimers of type A. Four compounds, $\mathbf{7 9}$ [78], 80 [79], 81 [80] and 82 [45] exhibit linear ribbon type hydrogen bonding of category $\mathbf{B}$. 


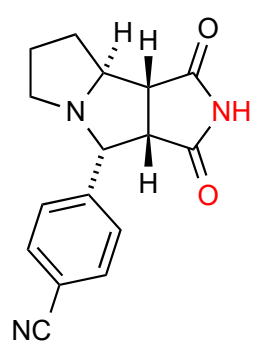

77 (LAWKAW)

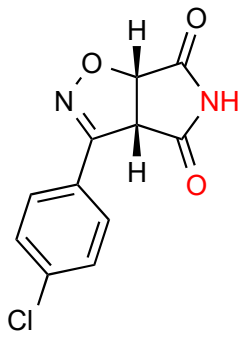

78 (ERORAG)

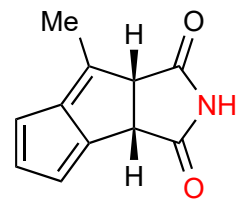

79 (XOFYEW)

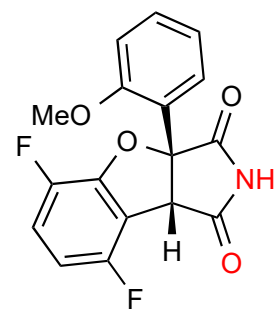

80 (TIXBUY)

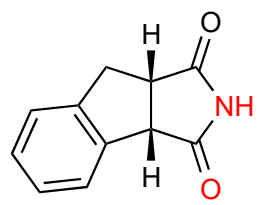

81 (QICWOO)

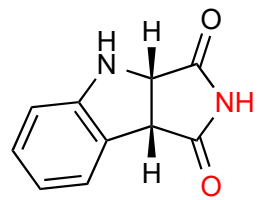

82 (BUVGAC)

Figure 28. Five-membered ring-fused succinimides showing patterns $\mathbf{A}$ and $\mathbf{B}$.

Two structures, compounds 83 [76] which is a stereoisomer of 77, and 84 [81] (Figure 29), exist in type $\mathbf{E}$ linear chains $(C(11)$ and $C(6)$, respectively) where the imide $\mathrm{NH}$ is linked to a remote nitrogen of the next molecule. Compound 85 [81] shows a linear $C(10)$ chain of molecules in pattern $\mathbf{F}$ where the imide $\mathrm{NH}$ is interacting with the remote $\mathrm{CO}$ of the methyl ester group in the next molecule.

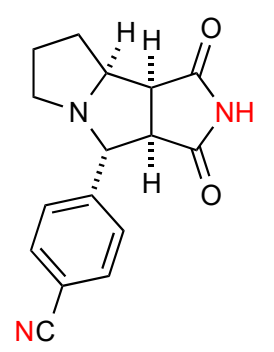

83 (RAZLAG)

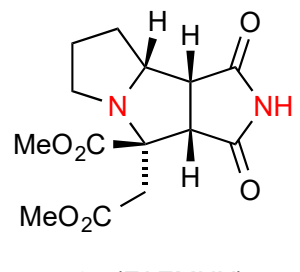

84 (FAFMUX)<smiles>COC/C(=C\C(=O)OC)N1[C@H](C(C)=O)[C@@]2(CC(C)=O)C(=O)NC(=O)[C@H]2[C@H]1Cc1ccccc1</smiles>

85 (FAFPOU)

Figure 29. Five-membered ring-fused succinimides showing patterns $\mathbf{E}$ and $\mathbf{F}$.

Compound 86 [82] (Figure 30) is one example of a category $\mathbf{H}$ pattern where there is a bis imide linkage. It forms dimers by bonding between the pyrrolidine-fused succinimide's $\mathrm{NH}$ and $\mathrm{CO}$ and these are then further linked into a chain by bonding between the $\mathrm{CO}$ and $\mathrm{NH}$ of the spirocyclically linked succinimides, giving an overall $C(14)\left[R^{2}{ }_{2}(8), R^{2}{ }_{2}(8)\right]$ pattern. Two structures, compounds 87 [83] and 88 [84] form type $\mathbf{D}$ dimers $\left(R^{2}{ }_{2}(14)\right)$ where the imide $\mathrm{NH}$ is bonded to a remote $\mathrm{CO}$ of another molecule and vice versa.<smiles>O=C1C=Cc2ccccc2[C@@]23C(=O)NC(=O)N2[C@@]2(C1)C(=O)NC(=O)[C@H]32</smiles>

$86(X A B Q A V)$<smiles>O=C1NC(=O)[C@@H]2ON3c4ccccc4C(=O)[C@@]3(c3ccccc3)[C@H]12</smiles>

87 (SUWXUD)<smiles>O=C1NC(=O)[C@]23Cc4ccccc4C(=O)[C@@]2(NC3=O)[C@@H]1Cc1ccccc1</smiles>

88 (PIFHAQ)

Figure 30. Five-membered ring fused succinimides showing patterns $\mathbf{H}$ and $\mathbf{D}$.

The three remaining structures display more complex patterns. In compound 89 [85] (Figure 31) imide $\mathrm{NH}$ to $\mathrm{CO}$ dimers are linked in a row held together by $\mathrm{OH}$ to benzoyl $\mathrm{CO}$ hydrogen bonding. The combination of $C(8)$ and $R^{2}{ }_{2}(8)$ creates $R_{4}^{4}(32)$ rings. 
<smiles>O=C1NC(=O)c2ncc(C(=O)c3ccccc3)c([18OH])c2C1=O</smiles>

89 (YAJPEH)

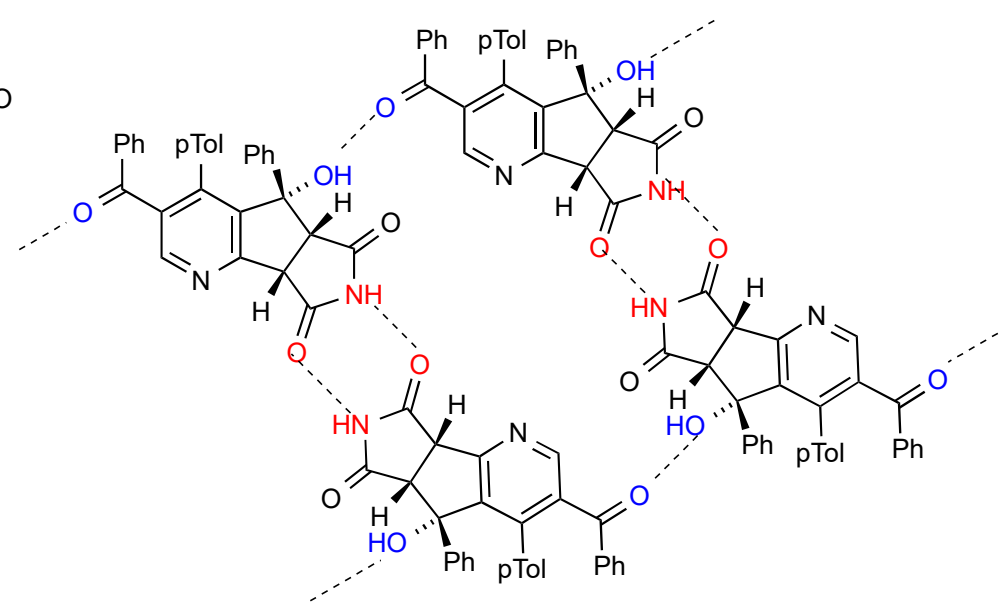

Figure 31. Structure adopted by compound 89 .

In compound 90 [86] (Figure 32) $R^{2}{ }_{2}(14)$ dimers formed by interaction of the imide $\mathrm{NH}$ with the oxazine $\mathrm{O}$ are further linked into a complex three-dimensional array by imide $\mathrm{CO}$ to oxazine $\mathrm{NH}$ $C(7)$ interactions.<smiles></smiles>

90 (KIMMAX)

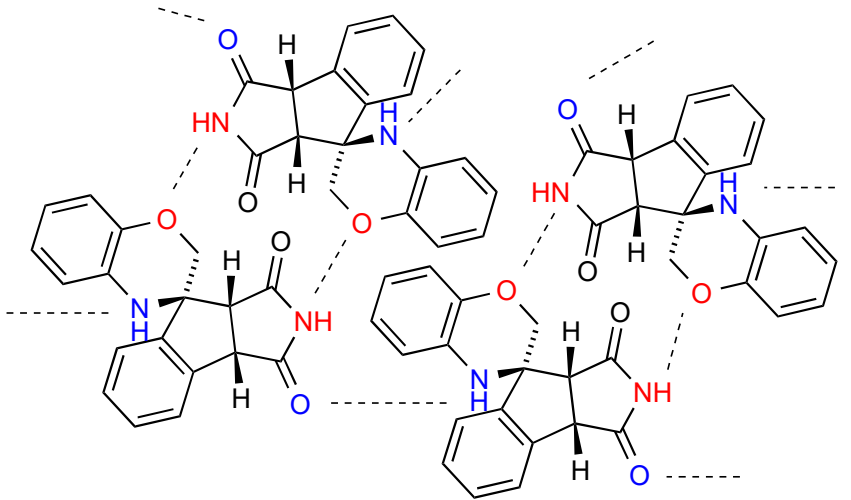

Figure 32. Structure adopted by compound 90.

In the final compound 91 [87] (Figure 33) there is $C(5)$ hydrogen bonding between the imide $\mathrm{NH}$ of one molecule and the oxazoline nitrogen of the next molecule. This compound thus exists as a helix with a five molecule repeat unit.

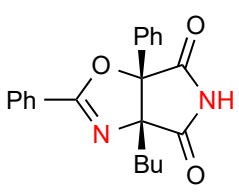

91 (MILGEV)

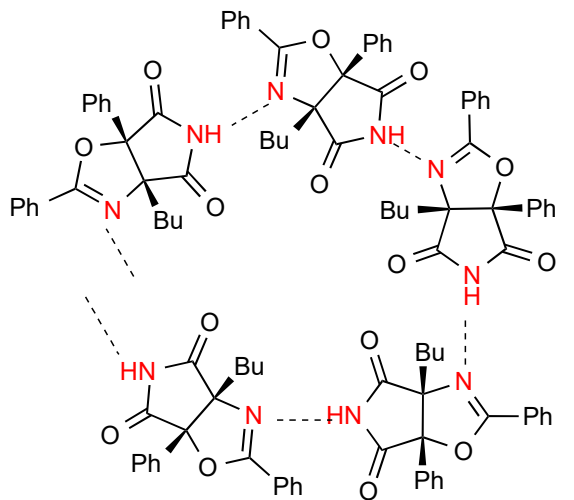

Figure 33. Structure adopted by compound 91. 


\subsection{Succinimides Fused to Six-Membered Rings}

Twenty-seven structures were located for succinimides fused to six-membered rings. Of these six structures, compounds 92 [88], 93 [89], 94 [90], 95 [91], 96 [92] and 97 [93] (Figure 34), exist as simple dimers of type $\mathbf{A}$.<smiles>CCOC(=O)n1c2c(c3ccccc31)C(=O)[C@H](OC)[C@@H]1C(=O)NC(=O)[C@H]21</smiles>

92 (ZUKVIK)<smiles>C[C@@]12C(=O)NC(=O)[C@]1(C)[C@H](c1ccccc1)OC1=C2CCCC1</smiles>

95 (LEQDUJ)<smiles>COc1cc(OC)c2c(c1)OC[C@@H]1C(=O)NC(=O)[C@@H]21</smiles>

93 (EYEREH)<smiles>CC(=O)OC[C@H]1CC[C@@H](C)[C@H]2C(=O)NC(=O)[C@H]12</smiles>

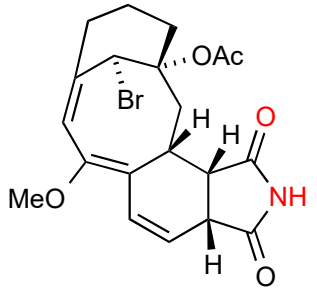

94 (HIFNEP)<smiles>[13CH3][C@@H]1[C@H]2C[C@@H]3C(=O)NC(=O)[C@H]3C[C@H]21</smiles>

97 (XUBBIH)

Figure 34. Six-membered ring-fused succinimides showing pattern A dimers.

Six of the reported structures, compounds $\mathbf{9 8}$ [94], 99 [95,96], 100 [97], 101 [89], 102 [98] and 103 [99] (Figure 35) exhibit a linear ribbon structure of pattern $\mathbf{B}$.

Six compounds, 104 [85], 105 [100], 106 [101], 107 [102,103], 108 [104] and $\mathbf{1 0 9}$ [105] (Figure 36) are observed in a linear chain with the imide $\mathrm{NH}$ bound to a remote oxygen of the next molecule in the type $\mathbf{F}$ pattern (respective designations $C(10), C(6), C(9), C(8), C(11)$ and $C(7)$ ). As shown there is an additional intramolecular $S(6)$ interaction in 104.

The bis imide compound 110 [106] (Figure 37) displays a head to tail doubly linked $C(10)\left[R^{2}{ }_{2}(8)\right]$ chain $\mathbf{H}$. Two structures reported, compounds 111 [107] and 112 [108] have the imide NH linked to a remote oxygen and form dimers of pattern $\mathbf{D}$ (respectively, $R^{2}{ }_{2}(18)$ and $R^{2}{ }_{2}(16)$ ).<smiles>O=C1NC(=O)[C@H]2CCCC[C@H]12</smiles>

98 (IHEPUG)<smiles>O=C1NC(=O)C2c3ccccc3SCC12</smiles>

101 (EYERIL)<smiles>O=C1NC(=O)[C@H]2CCCC[C@H]12</smiles>

99 (IHEPUG01, IHEPUG02)<smiles>CCC1=C2C(=O)NC(=O)C2CCO1</smiles>

102 (VOBDEV)<smiles>O=C1NC(=O)[C@H]2CC=CC[C@H]12</smiles>

100 (PHYPHM)

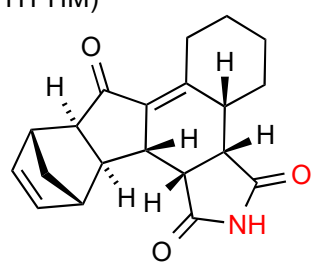

103 (PAKRUP)

Figure 35. Six-membered ring-fused succinimides showing pattern $\mathbf{B}$ ribbons. 


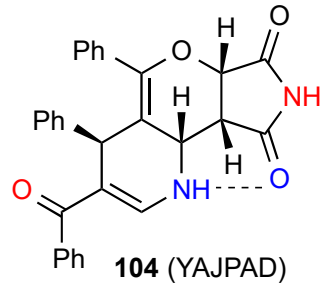

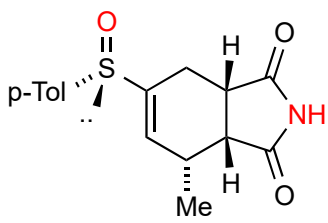

107 (WEWCAC10, WEWCAC91)<smiles>O=C1C[C@H]2C(=O)NC(=O)[C@@H]2C(=O)N1</smiles>

105 (BOCJOS)<smiles></smiles>

108 (UZIMIB)<smiles>CCOC(=O)CC[C@H]1C=C2c3ccccc3N[C@@H]2[C@H]2C(=O)NC(=O)[C@H]12</smiles>

106 (QOVQID)<smiles>Cc1cccc2c1C(=O)C[C@H]1C(=O)NC(=O)[C@H]21</smiles>

109 (VOHQER)

Figure 36. Six-membered ring-fused succinimides showing pattern F.<smiles>CC1(C)OB([C@@H]2C(Pc3ccccc3)=C3C[C@H]4C(=O)NC(=O)[C@@H]4C[C@H]3C3C(=O)NC(=O)[C@@H]32)OC1(C)C</smiles><smiles>CCOCCCCC1=C(C)C[C@H]2C(=O)NC(=O)[C@@H]2[C@H]2CCC(=O)CCC12</smiles><smiles>CC(F)O[R10](F)(F)F</smiles>

Figure 37. Six-membered ring-fused succinimides showing patterns $\mathbf{H}$ and $\mathbf{D}$.

Compound 113 [101] (Figure 38) exhibits a pattern where two molecules form imide NH to imide $\mathrm{CO}$ dimers which are further cross-linked to other dimer units by interaction of the other imide $\mathrm{CO}$ with the hydroxylamine OH forming a zig-zag $C(13)\left[R^{2}{ }_{2}(8), R^{2}{ }_{2}(16)\right]$ structure.

The structure of 114 [109] (Figure 39) shows imide $\mathrm{NH}$ to imide $\mathrm{CO} R^{2}{ }_{2}(8)$ dimers further bonded to adjacent such dimers by an indole $\mathrm{NH}$ to imide $\mathrm{CO} C(7)$ interaction giving rise to a complex cross-linked network.

The compound 115 [92] (Figure 40) exhibits parallel chains of molecules hydrogen bonded to each other by imide $\mathrm{NH}$ to alcohol $\mathrm{O} C(7)$ interactions (category $\mathbf{F}$ ). The chains are then cross-linked by imide $\mathrm{CO}$ to alcohol $\mathrm{H} C(8)$ bonding giving a two-dimensional network containing $R^{4}{ }_{4}(21)$ units.<smiles>Cc1ccccc1N(O)[C@H]1C[C@H]2C(=O)NC(=O)[C@@H]2c2[n-]c3ccccc3c21</smiles>

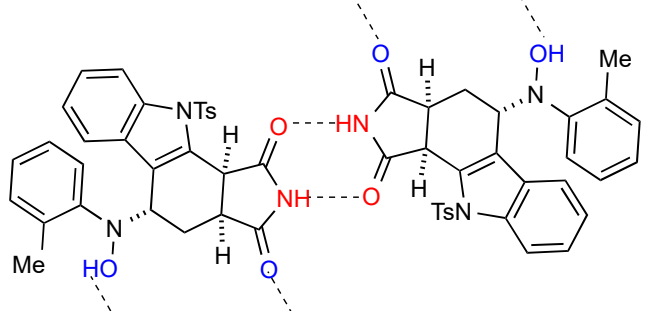

113 (QOVQOJ)

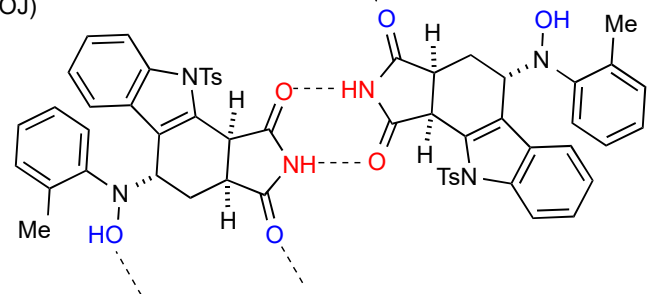

Figure 38. Structure adopted by compound 113. 


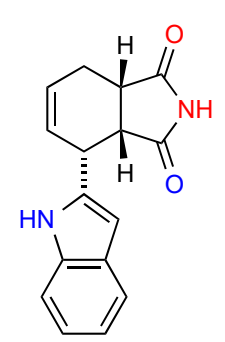

114 (SOXREE)

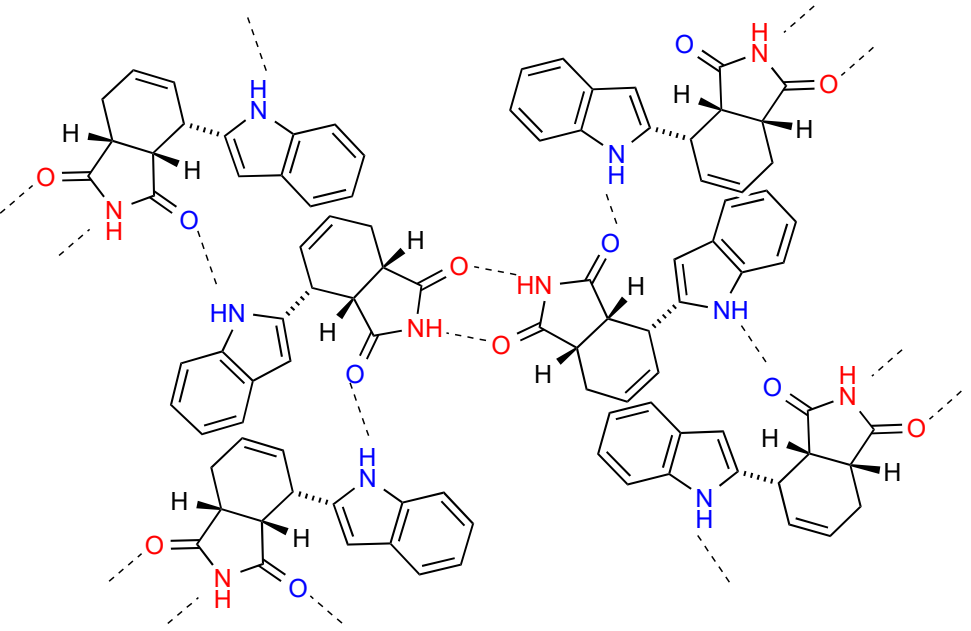

Figure 39. Structure adopted by compound 114.
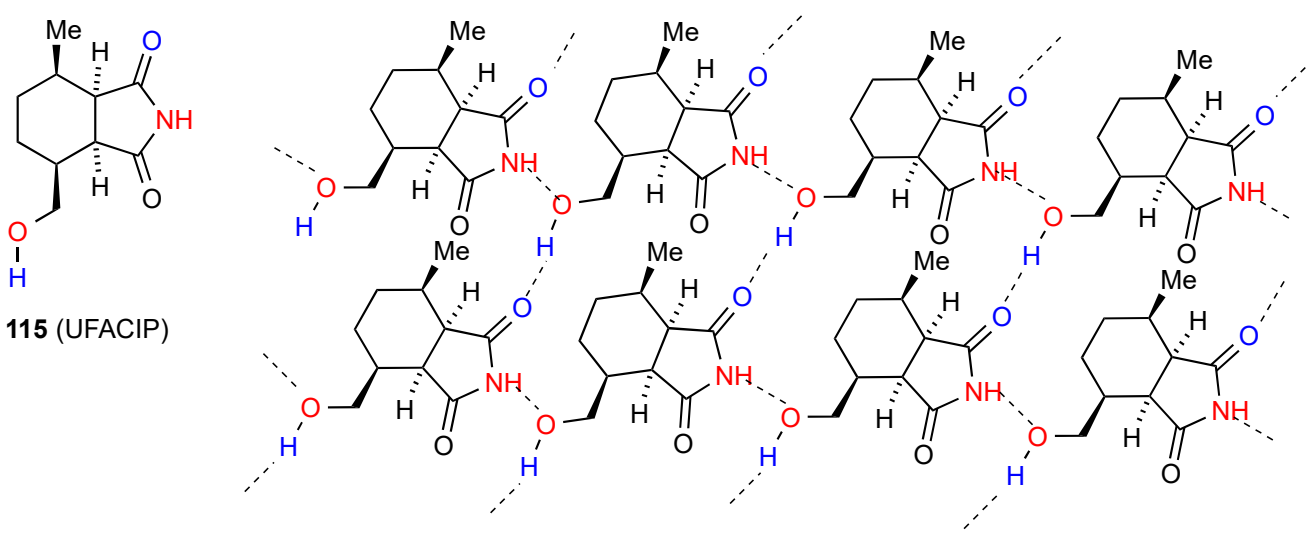

Figure 40. Structure adopted by compound 115.

Three more compounds also show more complex patterns of hydrogen bonding. Compound 116 [110] (Figure 41) is a bis imide but one of the imide groups is not involved in the hydrogen bonding. The other imide group forms linear $C(4)$ chains of type $\mathbf{B}$.

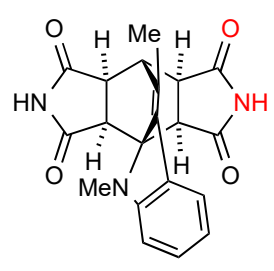

116 (WALYEN)

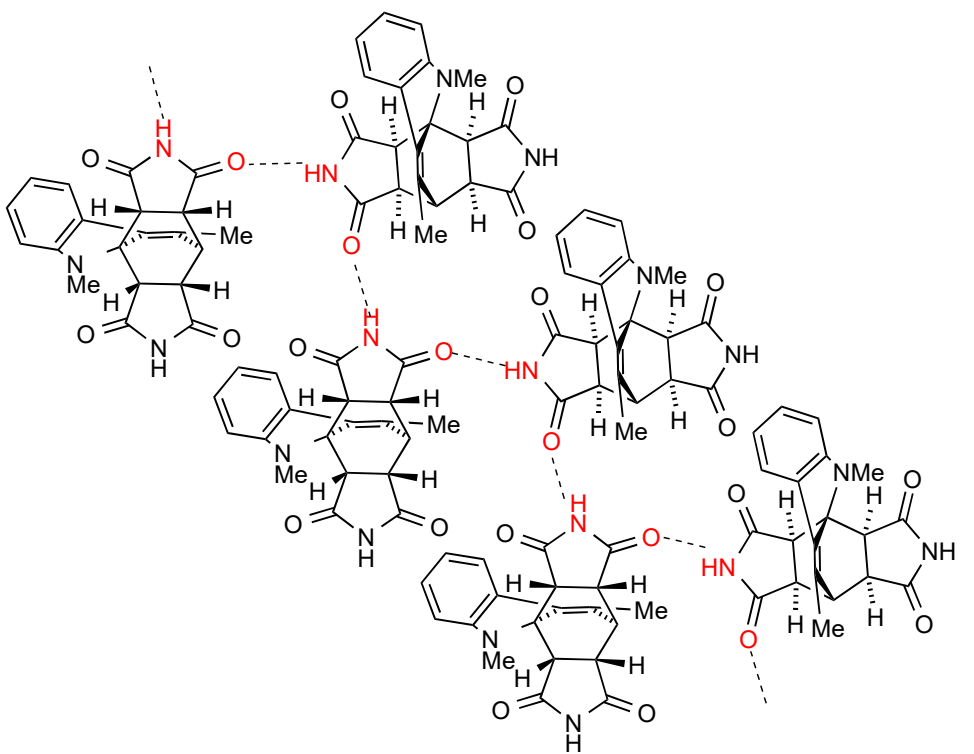

Figure 41. Structure adopted by compound 116. 
Compound 117 [111] (Figure 42) displays linear C(10) chains with imide NH to ester CO links. These chains are further linked by $R^{2}{ }_{2}(18)$ dimer formation between the imide $\mathrm{CO}$ and the alcohol $\mathrm{OH}$ on the eight-membered ring.

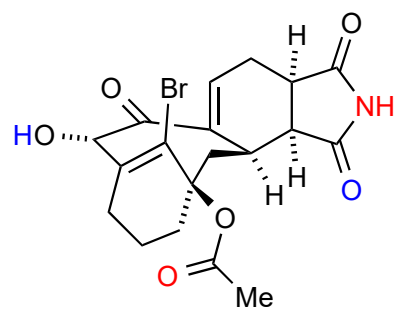

117 (WISHEL)

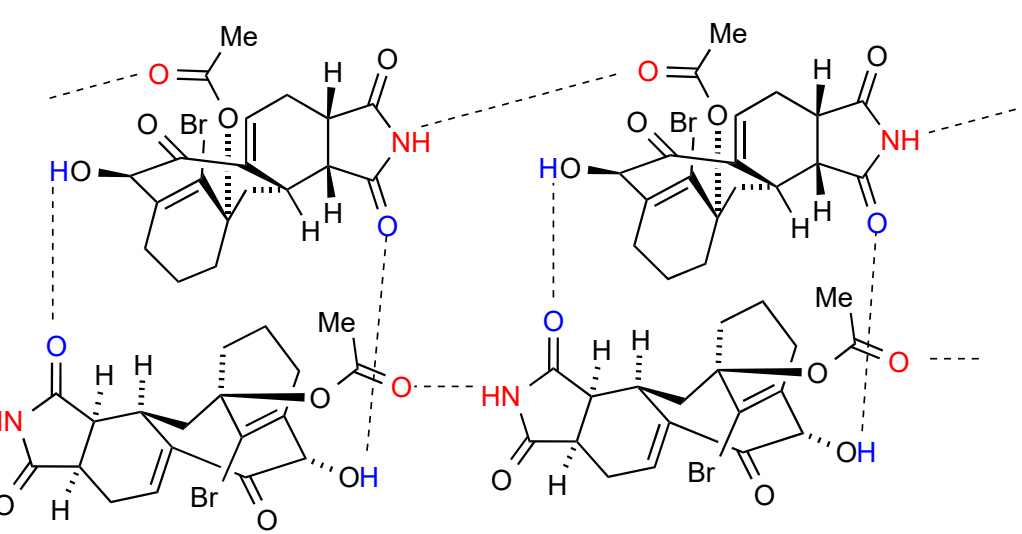

Figure 42. Structure adopted by compound 117.

The final structure, compound 118 [112] (Figure 43) exists as imide NH to sulfonyl SO $R^{2}{ }_{2}(16)$ dimers that are further cross-linked to each other by an $R^{2}{ }_{2}(12)$ interaction of sulfonamide $\mathrm{NH}$ and an imide $\mathrm{CO}$ in the same unit, thus setting up also two $R^{2}{ }_{2}(8)$ units.<smiles>O=C1NC(=O)[C@H]2CC=CC(NS(=O)(=O)c3ccccc3)C12</smiles>

118 (YEXTUQ)

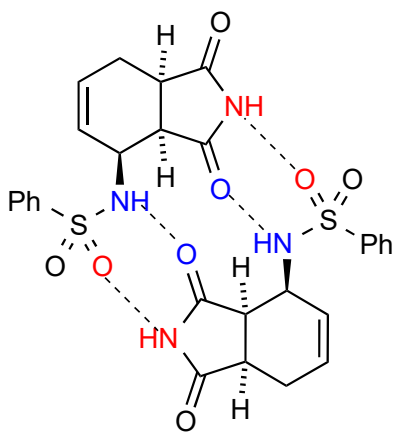

Figure 43. Structure adopted by compound 118.

\subsection{Bicyclo[2.2.1] and [2.2.2]-Fused Succinimides from Diels Alder Reactions}

Maleimide is a good dienophile in the Diels-Alder reaction and, as a result, a large number of such adducts have been prepared and in many cases, characterised by X-ray crystallography. Fifty structures have been located for Diels-Alder adducts containing succinimides. Fifteen structures, for compounds 119 [85], 120 [113], 121 [114], 122 [114], 123 [115], 124 [116], 125 [117], 126 [118], 127 [119], 128 [119], $\mathbf{1 2 9}$ [120], $\mathbf{1 3 0}$ [121], $\mathbf{1 3 1}$ [122] and $\mathbf{1 3 2}$ [123] (Figure 44) exist as simple $R^{2}{ }_{2}(8)$ dimer units of pattern $\mathbf{A}$. It should be noted that these dimer structures of compound $\mathbf{1 3 0}$ contain toluene or $o$-dichlorobenzene whereas in the absence of solvent, this compound forms pattern $\mathbf{B}$ ribbons (see below).

Twenty structures exhibit a linear ribbon type of hydrogen bonding $(C(4))$ in pattern $\mathbf{B}$. These are compounds 133 [122], 134 [124], 135 [120], 136 [125], 137 [126], 138 [126], 139 [127], 140 [128], 130 [121], 141 [129], 142 [124], 143 [130,131], 144 [132], 145 [132], 146 [119], 147 [119], 148 [113], 149 [133] and 150 [134] (Figure 45). 


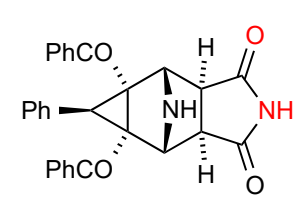

119 (YAJNOP)

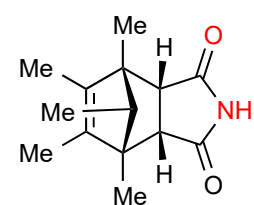

120 (XOTDIU)

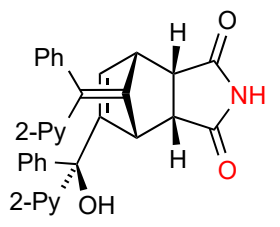

121 (ETONOQ)

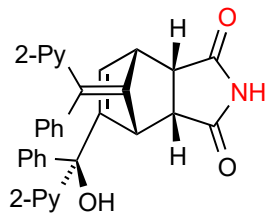

122 (ETONUW)

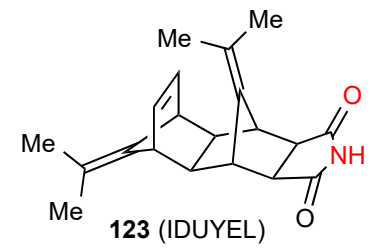<smiles>[R]c1ccc(/C=C2/[C@H]3C=C[C@H]2[C@@H]2C(=O)NC(=O)[C@@H](C)[C@H]32)cc1</smiles>

$124 \mathrm{R}=\mathrm{H}$ (IJIJUH)<smiles>CC(C)CP1P2C(c3ccccc3)=C(c3ccccc3)C1(c1ccccc1)C1C(=O)NC(=O)C12</smiles>
126 (SOTGAK)<smiles>CC(=O)OC1=C[C@@H]2C=C[C@@H](OC(C)=O)[C@H]1C(=O)NC2=O</smiles>

129 (HOPJON)

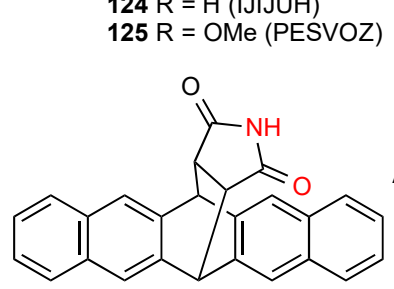<smiles>[R9]NC(=O)OC1=C[C@@H]2C[C@H]1[C@@H]1C(=O)NC(=O)[C@@H]21</smiles><smiles>[R]C12CC=CC(C1)C1C(=O)NC(=O)C12</smiles>

$127 \mathrm{R}=\mathrm{H}$ (PUMVOJ) $128 \mathrm{R}=\mathrm{Et}$ (PUMVUP)

130 (KIDMOA, KIDMIU)

Figure 44. Bicyclo[2.2.1] and [2.2.2]-fused succinimides showing pattern A dimers.<smiles>O=C1CC2CC3C(=O)NC(=O)C3C2C1</smiles>

133 (AFUNEV)<smiles>[R]C12CCC(CC1=O)[C@H]1C(=O)NC(=O)[C@@H]12</smiles>

$137 \mathrm{R}=\mathrm{Me}$ (WOLFUA) $138 \mathrm{R}=\mathrm{Et}(\mathrm{WOLHIQ})$<smiles>CCOC(=O)C1C2C(=O)NC(=O)C3C2CC1C3(C)CC</smiles>

134 (DORVOX)<smiles>COC1=CC(OCC(C)C)C2C(=O)NC(=O)C2C1O</smiles>

135 (HOPJIH)

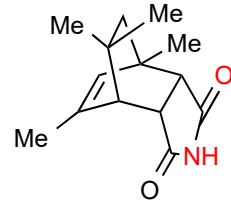

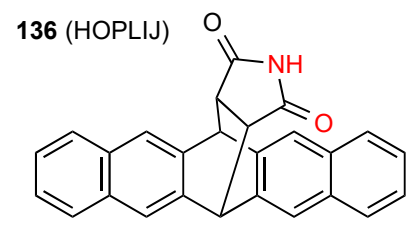

130 (KIDNAN)<smiles>CC12C=CC(C)(O1)C1C(=O)NC(=O)C12</smiles>

141 (BUVNAJ)<smiles>CC1=CC2OC1C1C(=O)NC(=O)C21</smiles>

147 (PUMWAW)<smiles>CC(=O)OC12C[C@H]1[C@@H]1C(=O)NC(=O)C(=O)[C@@H]1C2</smiles>

142 (DORVIR)

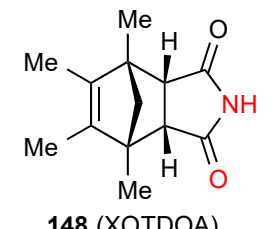

148 (XOTDOA)<smiles>C[C@]12C(=O)NC(=O)[C@H]1[C@H]1CC[C@H]2O1</smiles>

143 (LADCEB, LADCEB01)<smiles>CNC(=O)NC(=O)C1(C)C2C=CC3CC(C2)C31C</smiles>
140 (YITBUY)<smiles>[R]c1ccc(/C=C2\[C@H]3C[C@H]4[C@@H]2[C@H]2C(=O)NC(=O)[C@H]4[C@@H]32)cc1</smiles>

$144 \mathrm{R}=\mathrm{Me}(\mathrm{PEMWUA})$

$145 \mathrm{R}=$ OMe (PEMWOU)<smiles>O=C1NC(=O)C2C1C1C=CC2(c2ccc(-c3ccco3)o2)O1</smiles><smiles></smiles>

150 (MINQEI)<smiles>O=C1NC(=O)C2C1C1C=CC2(Cn2cccc2)O1</smiles>

146 (PUMWIE)

Figure 45. Bicyclo[2.2.1] and [2.2.2]-fused succinimides showing pattern B ribbons.

One structure, compound 151 [135] (Figure 46) exhibits the square hydrogen bonding $R^{4}{ }_{4}(16)$ pattern G involving four molecules. Eight of the reported structures, compounds 152 [126], 153 [126], $\mathbf{1 5 4}$ [126], 155 [136,137], 156 [119], 157 [138], 158 [138] and $\mathbf{1 5 9}$ [139] (Figure 46) show linear chains, respectively $C(7), C(8), C(7), C(8), C(6), C(8), C(10)$ and $C(6)$, where the imide $\mathrm{NH}$ is linked to a remote oxygen of the next molecule in pattern $\mathbf{F}$. 
<smiles>COC1(OC)C2(Cl)C(Cl)=C(Cl)C1(Cl)C1C(=O)NC(=O)C12</smiles>

151 (HUJQOT)<smiles>CC(C)OC12CC(=O)C3CC1C(C(=O)NC3=O)C2O</smiles>

152 (WOLGAH)<smiles>CC(=O)OC12CCC(CC1=O)[C@H]1C(=O)NC(=O)[C@H]12</smiles>

153 (WOLGEL)<smiles>O=C1CC2C(=O)CC1C1CC2C(=O)N1</smiles>

154 (WOLGOV)<smiles>CN1C(=O)C23C=CC(C4C(=O)NC(=O)C42)C2C=CC3c3ccccc3N21</smiles>

155 (XOLNIW)

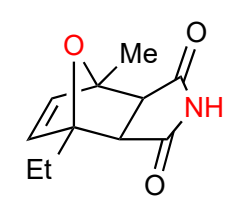

156 (PUMWEA)<smiles>CC1(C)O[C@H]2[C@@H](CO)O[C@H]([C@H]3C=C[C@H]4O[C@H]3[C@H]3C(=O)NC(=O)[C@H]34)[C@H]2O1</smiles>

157 (DUHNOJ)<smiles>O=C1NC(=O)[C@@H]2[C@@H]1[C@H]1C=C[C@H]([C@H]3O[C@H](CO)[C@@H](O)[C@H]3O)[C@H]12</smiles><smiles>CC(C)(C)OCC12C=CC(O1)C1C(=O)NC(=O)C12</smiles>

Figure 46. Bicyclo[2.2.1] and [2.2.2]-fused succinimides showing patterns $\mathbf{G}$ and $\mathbf{F}$.

Compound 160 [126] (Figure 47) exists as a $R^{2}{ }_{2}(14)$ dimer of category $\mathbf{D}$ with the imide $\mathrm{NH}$ of one molecule interacting with the bridging $\mathrm{CO}$ of the other and vice versa. Two structures exist in the form of compounds 161 [140] and 162 [140] that are too hindered and thus exhibit no hydrogen bonding pattern at all.

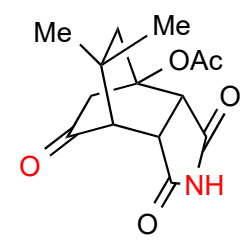

160 (WOLGIP)

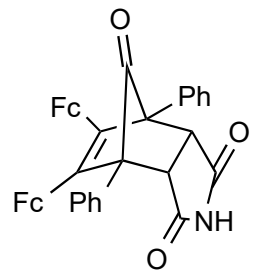

$161 \mathrm{Fc}=2$-ferrocenyl (EWISEK)

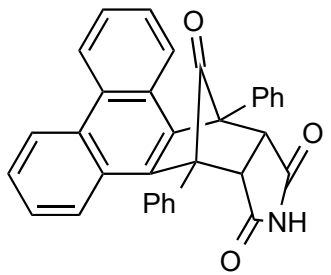

$162(E W I R O T)$

Figure 47. Bicyclo[2.2.1] and [2.2.2]-fused succinimides showing pattern D or no hydrogen bonding.

The remaining three structures exhibit more complex patterns of H-bonding. Compound 163 [141] (Figure 48) has imide $\mathrm{NH}$ to imide $\mathrm{CO} R^{2}{ }_{2}(8)$ dimers which are cross-linked to each other by the $R^{3}{ }_{3}(12)$ interactions of the alcohol OH groups forming a network containing $R_{4}^{4}(28)$ units.

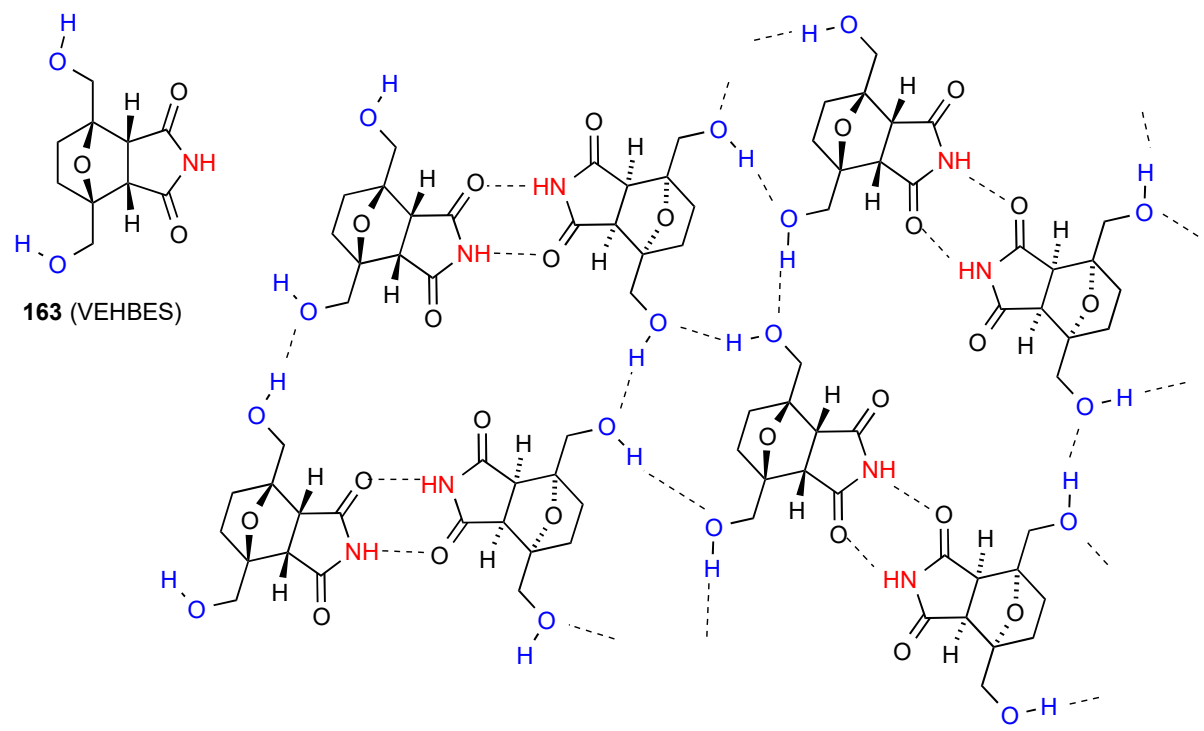

Figure 48. Structure adopted by compound 163. 
Compound 164 [131] (Figure 49) forms a ribbon in which two parallel rows of molecules are linked by one imide $\mathrm{CO}$ of each molecule being equally hydrogen bonded to both an imide $\mathrm{NH}$ and an alcohol $\mathrm{OH}$ of separate molecules in the other row. In this way each molecule is involved in two $R^{2}{ }_{2}(10)$ units, one as the $C(4)$ component and one as the $C(6)$ component.

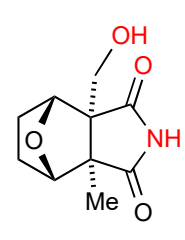

164 (EVIRIM)

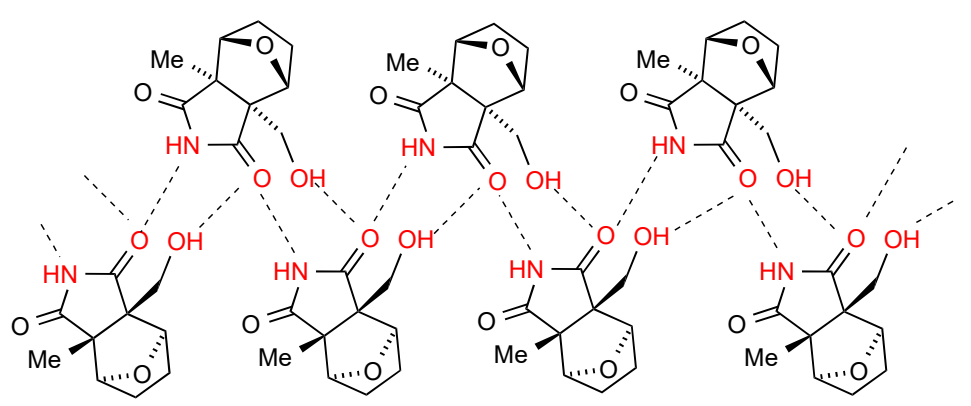

Figure 49. Structure adopted by compound 164 .

Compound 165 [142] (Figure 50) is a bis imide that forms a rare double linear ribbon pattern. The two imide rings at either end are essentially parallel and each pair bonds via imide $\mathrm{NH}$ to an imide $\mathrm{CO}$ of the next molecule giving two separate parallel $C(4)$ chains incorporating $R^{2}{ }_{2}(24)$ units.

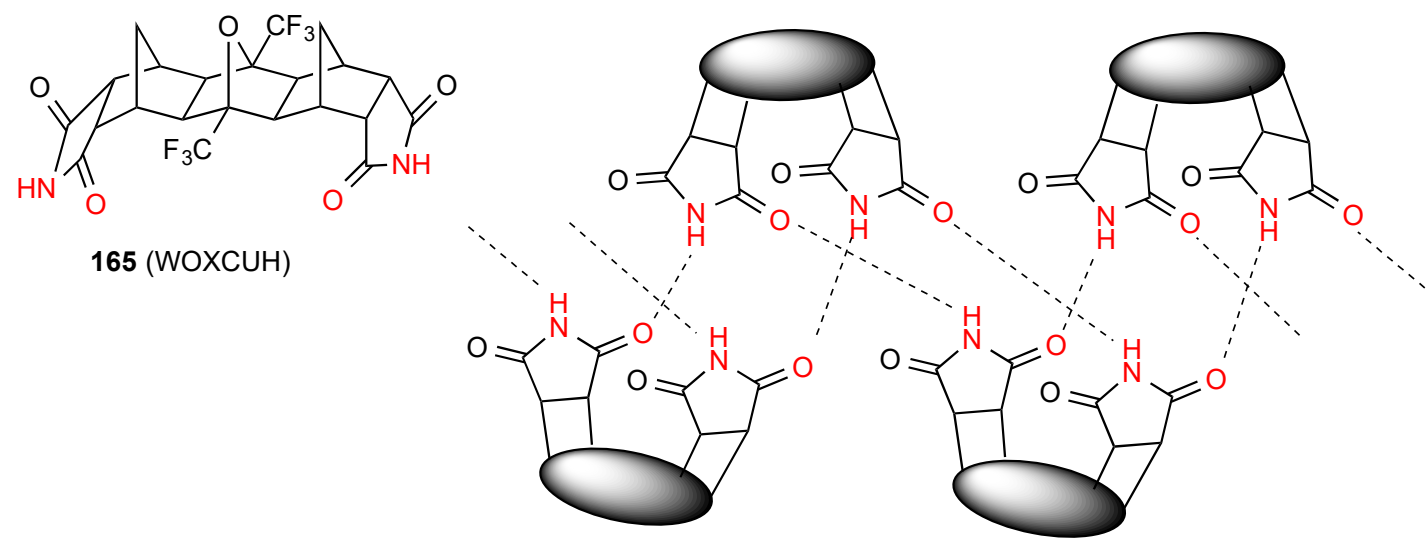

Figure 50. Structure adopted by compound 165.

\section{Unsaturated Glutarimides}

\subsection{Monocyclic Unsaturated Glutarimides}

Six structures have been reported for monocyclic unsaturated glutarimides. Four of these structures, compounds 166 [143], 167 [144], 168 [145] and 169 [146] (Figure 51) exist as simple $R^{2}{ }_{2}(8)$ dimers of category $\mathbf{A}$, with 166 and 168 displaying an additional intramolecular $S(6)$ interaction. Compound 170 [147] exists as a simple linear C(5) chain with the imide NH bonded to a remote oxygen on the next molecule in a type $\mathbf{F}$ pattern.

The remaining structure, compound 171 [148] (Figure 52) exhibits a more complex pattern similar to 31 and 66, with imide $\mathrm{NH}$ to imide $\mathrm{CO}$ dimers forming $R^{2}{ }_{2}(8)$ units which are linked to each other by $R^{2}{ }_{2}(10)$ interaction of the other imide $\mathrm{CO}$ with the $\mathrm{OH}$ substituent giving a chain with overall designation $C(11)\left[R^{2}{ }_{2}(8), R^{2}{ }_{2}(10)\right]$. 
<smiles>[Y16]C12CCCCC1c1ccccc1C(=C1C=C(c3ccccc3)C(=O)NC1=O)NC2</smiles><smiles>CCCCc1ccc(C=C2C(=O)NC(=O)C(C#N)=C2[N+](=O)[O-])s1</smiles><smiles>CCO[Mg]C1=C(C#N)C(=O)NC(=O)C1=CNc1ccc(Br)cc1</smiles>
166 (HINMEY)<smiles>CCC1(C(C)C)C=C(Br)C(=O)NC1=O</smiles>

169 (BPEGIM)

167 (QIRQAJ)<smiles></smiles>

170 (OLALAO)

Figure 51. Unsaturated glutarimides showing patterns $\mathbf{A}$ and $\mathbf{F}$.<smiles>[Y9]OC1(O)C=CC(=O)NC1=O</smiles>

171 (ZEDXEN)

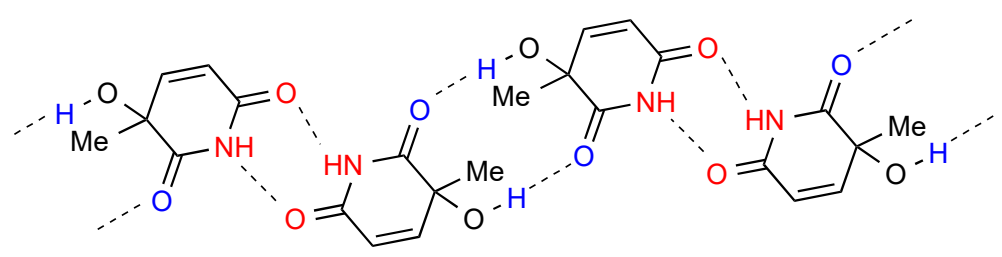

Figure 52. Structure adopted by compound 171.

\subsection{Ring-Fused Unsaturated Glutarimides}

Nine structures were located for ring-fused glutarimides of which six compounds 172 [149], $\mathbf{1 7 3}$ [150], 174 [151], 175 [152], 176 [153] and $\mathbf{1 7 7}$ [154] (Figure 53), exist as simple imide NH-CO $R^{2}{ }_{2}(8)$ dimers of type A. Compound $\mathbf{1 7 6}$ additionally has intramolecular $S(6)$ hydrogen bonding between the other imide $\mathrm{CO}$ and the enol $\mathrm{OH}$ on the fused ring.<smiles></smiles>

$172 \times=O(T I X S U R)$ $173 \times=\mathrm{NH}(\mathrm{IPOLOQ})$<smiles>Cn1nc2c(c1N)C(=O)NC(=O)C2</smiles>

174 (EGUHIZ)<smiles>CC1(C)N=C2C(=O)NC(=O)C(F)=C2O1</smiles>

175 (WINXIA)<smiles>CCCn1c(O)c2c(=O)[nH]c(=O)c(C#N)c-2c2ccccc21</smiles>

176 (YOWHEY)<smiles>N#CC1=C2CCCCC2(Br)C(=O)NC1=O</smiles>

$177(\mathrm{BXIQCN})$

Figure 53. Ring-fused unsaturated glutarimides showing pattern A.

The three remaining structures have complex hydrogen-bonding networks. Compound 178 [155] (Figure 54) forms $\mathrm{C}(6)$ chains linked both by interactions of imide $\mathrm{NH}$ to aldehyde $\mathrm{CO}$ and imide $\mathrm{CO}$ to pyrazole $\mathrm{NH}$, forming $R^{2}{ }_{2}(10)$ units. A series of antiparallel chains are then cross-linked by $C(8)$ amino to imide $\mathrm{CO}$ bonding, forming a two-dimensional network incorporating $R^{4}{ }_{4}(21)$ units.

Compound 179 [155] (Figure 55) exists as one of the most complex structures observed in this area. In each molecule, one imide $\mathrm{CO}$ is intramolecularly $S(6)$ hydrogen bonded to the enol $\mathrm{OH}$. The structure then consists of an alternating chain of two different types of $R^{2}{ }_{2}(8)$ dimer, one formed by imide $\mathrm{NH}$ to intramolecularly hydrogen-bonded imide $\mathrm{CO}$ interaction, and the other by imide $\mathrm{NH}$ to non-intramolecularly hydrogen-bonded $\mathrm{CO}$ interaction. These are then linked in a single $C(22)$ chain by bonding of the free imide $\mathrm{CO}$ of the former type to the pyrazolyl amino group of the latter. 
<smiles>Nc1[nH][nH]c2c(C=O)c(=O)[nH]c(=O)c1-2</smiles>

178 (MIMMEB)

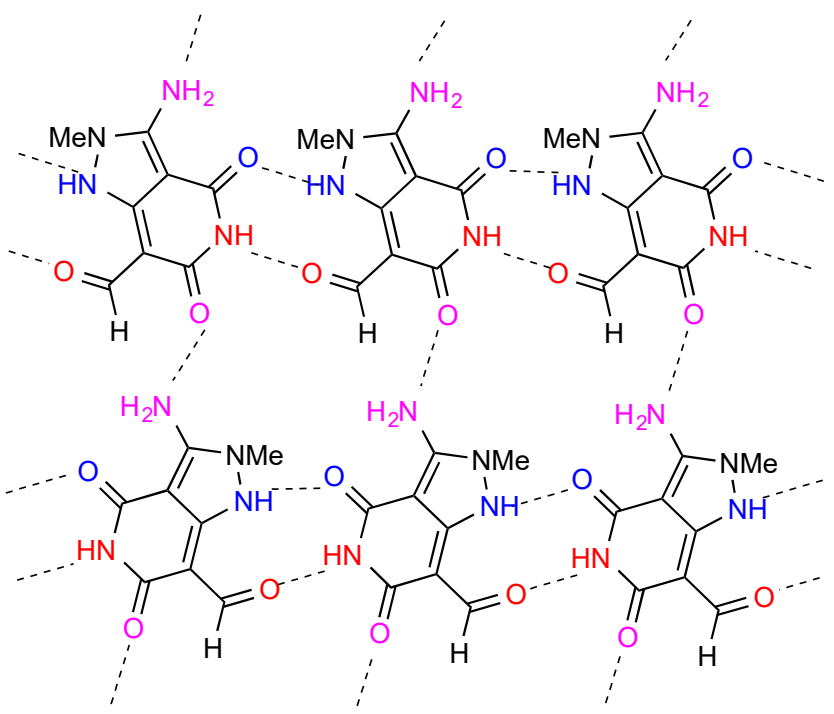

Figure 54. Structure adopted by compound 178.<smiles>CC(O)=C1C(=O)NC(=O)c2c1nn(C)c2N</smiles>

179 (MIMMIF)

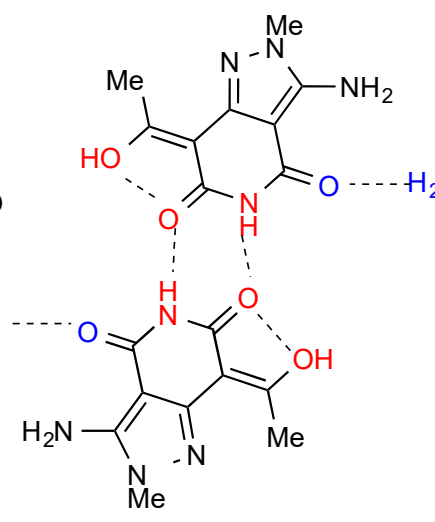

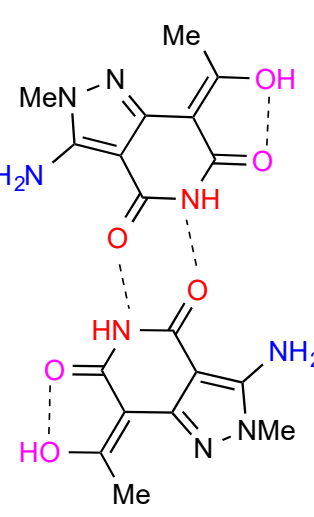

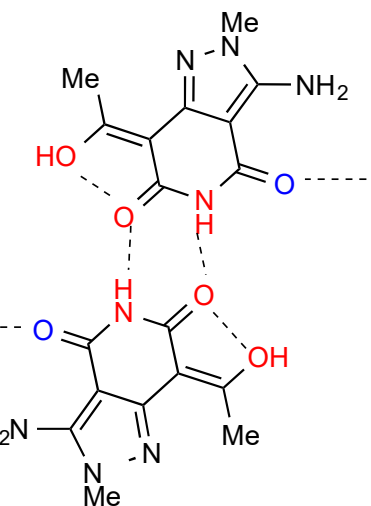

Figure 55. Structure adopted by compound 179.

Compound 180 [156] (Figure 56) exists as imide $\mathrm{NH}$ to imide $\mathrm{CO} \mathrm{R}^{2}{ }_{2}(8)$ dimers further linked in a chain by pyrrole $\mathrm{NH}$ to ester $\mathrm{CO} R^{2}{ }_{2}(10)$ interactions.<smiles>COC(=O)c1cc2c([nH]1)C(=O)C(=O)NC2=O</smiles>

180 (KIYQUF)<smiles>CCN1C(=O)C(=O)c2[nH]c(C(=O)OC)cc2C1=O</smiles>

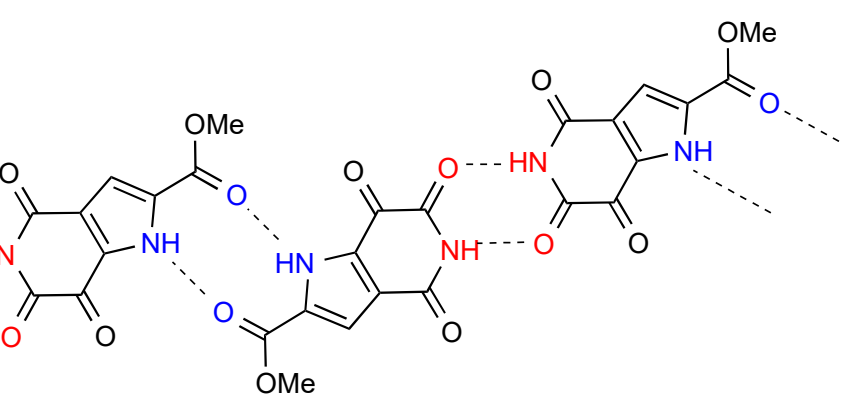

Figure 56. Structure adopted by compound $\mathbf{1 8 0}$. 


\section{Saturated Glutarimides}

\subsection{Glutarimide}

One structure has been published for parent glutarimide 181 [157] (Figure 57) which exhibits a ribbon structure of type $\mathbf{B}$ with $\mathrm{C}(4)$ imide $\mathrm{NH}$ - imide $\mathrm{CO}$ bonding between two rows of molecules.<smiles>O=C1CCCC(=O)N1</smiles>

181 (GLUTIM)<smiles>CC(C)NC1CCC(=O)NC1=O</smiles>

189 (JIJFEN)<smiles>C[C@H]1CC(=O)N(C2CCC(=O)NC2=O)C1=O</smiles>

193 (PONWIZ)<smiles>[R]c1ccc2c(c1)C(=O)N(C1CCC(=O)NC1=O)C2=O</smiles>

$182 \mathrm{R}=\mathrm{Br}(\mathrm{GABPHA} 10)$

$183 \mathrm{R}=\mathrm{NH}\left(\mathrm{CH}_{2}\right)_{4} \mathrm{Me}(\mathrm{BAZNEY})$

$184 \mathrm{R}=\mathrm{H}$ (ZORBEP, THALID10, THALID12)<smiles>[R]c1cccc2c1CN(C1CCC(=O)NC1=O)C2=O</smiles>

$190 \mathrm{R}=\mathrm{H}($ UZAGIN) $191 \mathrm{R}=\mathrm{NH}_{2}$ (AJISES)<smiles>[R]Nc1cccc2c1C(=O)N(C1CCC(=O)NC1=O)C2=O</smiles>

$185 \mathrm{R}=\mathrm{Ph}(\mathrm{HALKUC})$

$186 \mathrm{R}=\operatorname{Pr}(\mathrm{BAZMUN})$ $187 \mathrm{R}=\mathrm{iPr}(\mathrm{BAZNAU})$<smiles>O=C1CCC(N2NC(=O)[C@@H]3CCCC[C@@H]3C2=O)C(=O)N1</smiles>

192 (LILTEI)<smiles>O=C1CCC(N2C(=O)c3cccnc3C2=O)C(=O)N1</smiles>

188 (MICXUU)<smiles></smiles>

194 (YIHDUO)

Figure 57. Glutarimide (pattern B) and 3-monosubstituted glutarimides with pattern A structures.

\subsection{3-Monosubstituted Glutarimides}

Eighteen structures have been published for 3-monosubstituted glutarimides. Fifteen of these structures, compounds 182 [158], 183 [159], 184 [160-162], 185 [163], 186 [159], 187 [159], 188 [164], 189 [165], 190 [166], 191 [167], 192 [168], 193 [169] and 194 [170] (Figure 57) exist as simple $R^{2}{ }_{2}(8)$ dimers of pattern A. Compounds 185-187 have an additional S(6) interaction.

The remaining three structures exist with more complex forms of hydrogen bonding. Compound 195 [171] (Figure 58) is a second form of $\mathbf{1 9 1}$ whose structure is quite different. The primary interaction is between the imide $\mathrm{NH}$ and the lactam carbonyl, leading to a $C(7)$ ribbon structure as shown. However, this is then linked to further such chains both behind and in front of the plane by both imide carbonyls being bonded to amino $\mathrm{NH}$ and each amino group bonding to the imide $\mathrm{CO}$ of two separate molecules, forming a complex three-dimensional network.

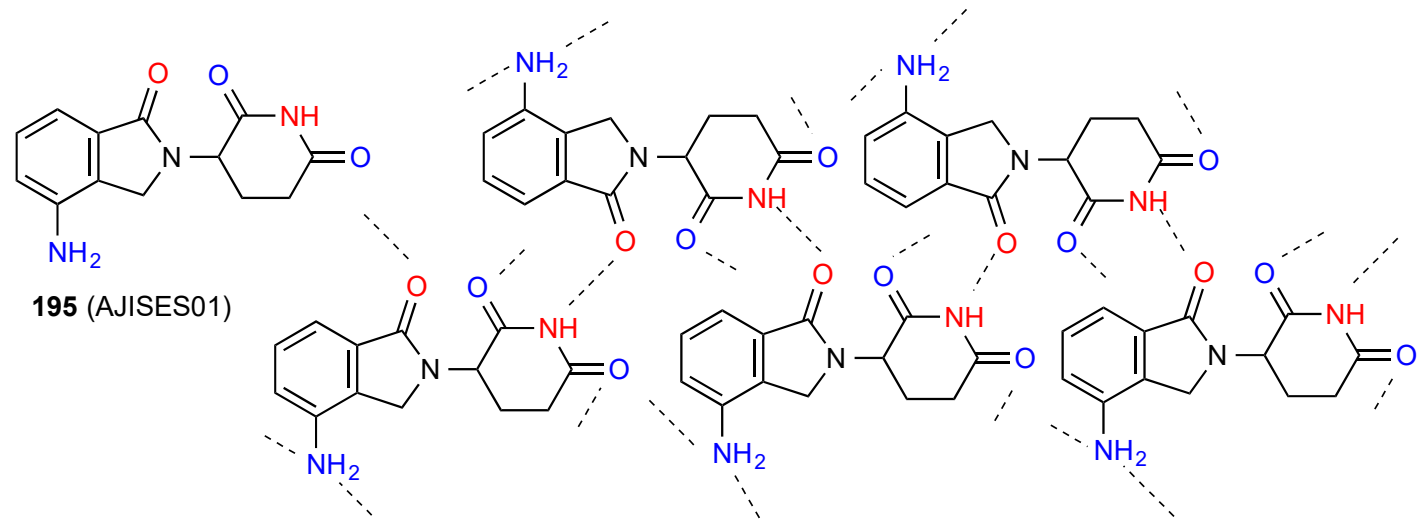

Figure 58. Structure adopted by compound 195. 
Compound 196 [163] (Figure 59), forms imide NH to imide CO $R^{2}{ }_{2}(8)$ dimers. These dimer units are further linked in $C(8)$ chains by the head-to-tail interaction of the phenylamino $\mathrm{NH}$ and one phthalimide CO between adjacent dimers, leading to formation of $R^{4}{ }_{4}(38)$ units.

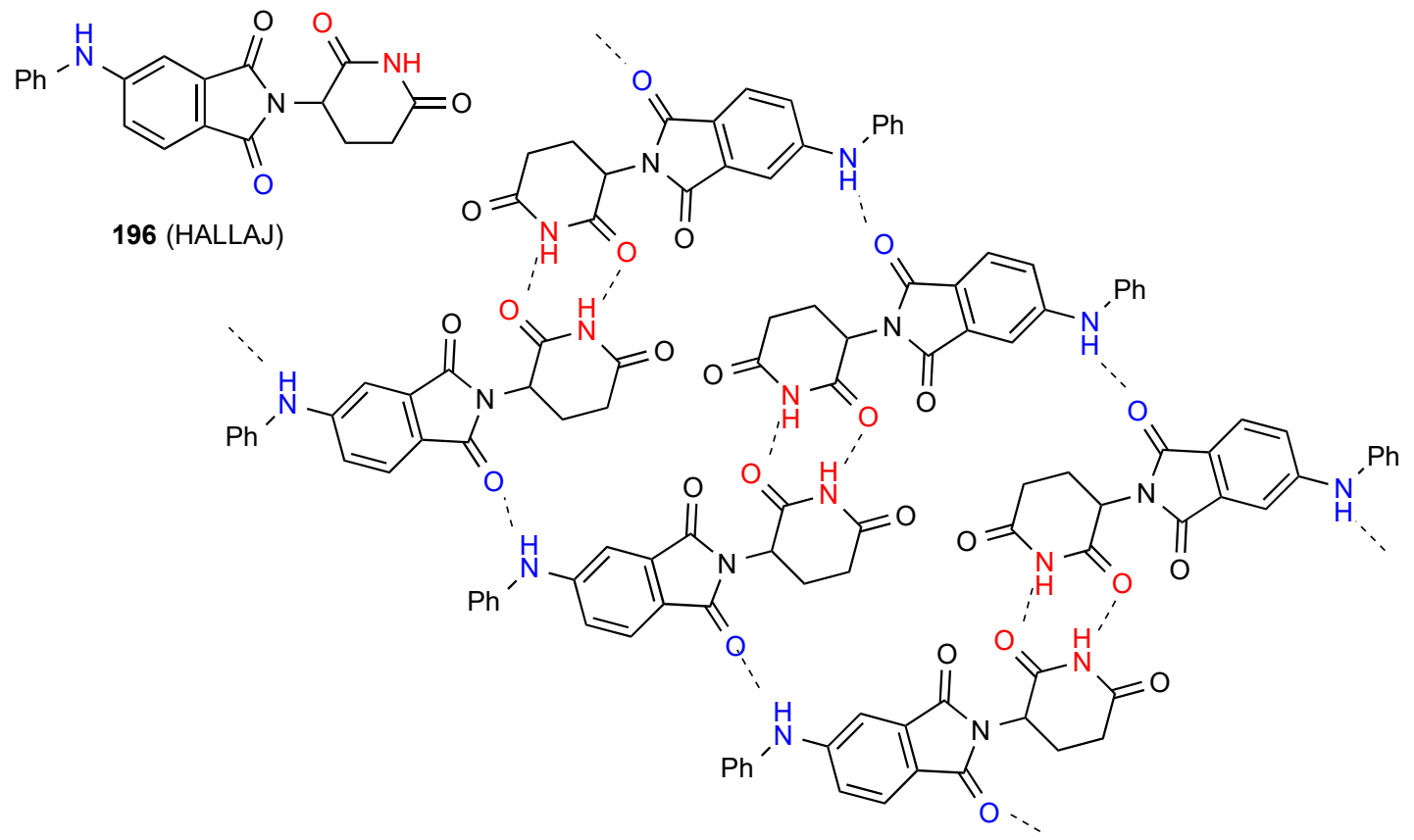

Figure 59. Structure adopted by compound 196.

Structure 197 [171] (Figure 60) is a further form of compound 191/195 that forms with half a molecule of acetone in the unit cell. In a similar way to compound $\mathbf{1 7 9}$ the structure contains two different types of imide $\mathrm{NH}$ to imide $\mathrm{CO}^{2}{ }_{2}(8)$ dimers differing in which $\mathrm{CO}$ is involved. These then bond together in a $C(34)$ chain by two amino groups of one unit linking to two lactam COs of separate molecules on either side of it.<smiles>Nc1cccc2c1CN(C1CCC(=O)NC1=O)C2=O</smiles>

197 (ICOTIG)<smiles>COC(=O)N1C(=O)c2cccc(N)c2CN1C1CCC(=O)NC1C1CCC(=O)N(C2Cc3c(N)cccc3C2=O)C1=O</smiles><smiles>CNc1cccc2c1CN(C1CCC(=O)NC(=O)C1N1Cc3c(N)cccc3C1=O)C2=O</smiles><smiles>COC(=O)N1Cc2c(N)cccc2C1N1CC(=[O+][O-])C(=O)NC1=O</smiles>

Figure 60. Structure adopted by compound 197. 


\subsection{4-Monosubstituted Glutarimides}

Five structures have been published for 4-monosubstituted glutarimides. Compound 198 [172] and 199 [173] (Figure 61) exist as simple $R^{2}{ }_{2}(8)$ dimers of type A with additional intramolecular $S(6)$ interactions as shown. The compounds 200 [174] and 201 [175] exhibit the linear $C(4)$ ribbon pattern $\mathbf{B}$ and again $\mathbf{2 0 0}$ has the intramolecular $S(6)$ interaction shown.
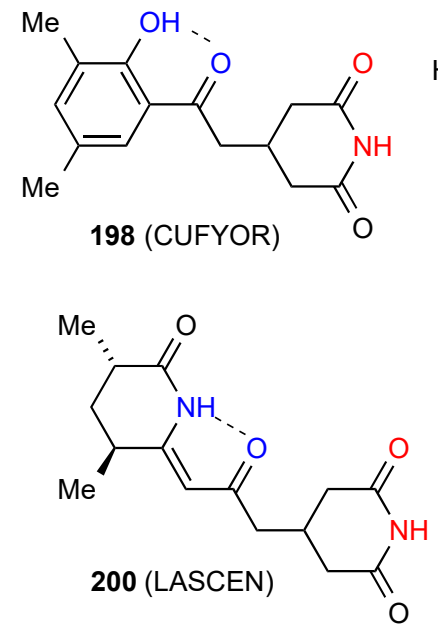
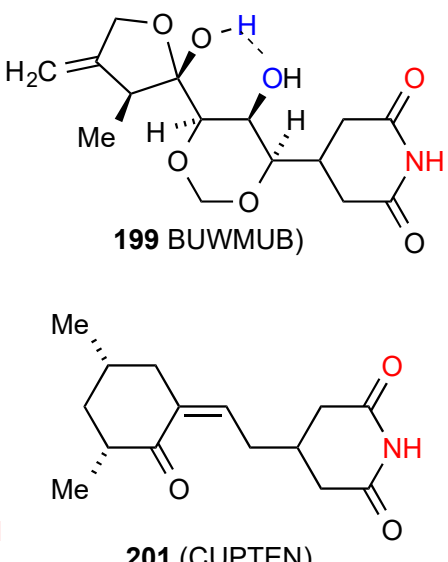

Figure 61. 4-Monosubstituted glutarimides of patterns A and B.

The remaining structure involves more complex bonding. Compound 202 [176] (Figure 62) displays primarily an imide $\mathrm{NH}$ to $\mathrm{CO} C(4)$ ribbon pattern of type $\mathbf{B}$ which is supplemented by an interaction of the same imide $\mathrm{CO}$ to an alcohol $\mathrm{OH}$ in a separate ribbon above or below the plane.

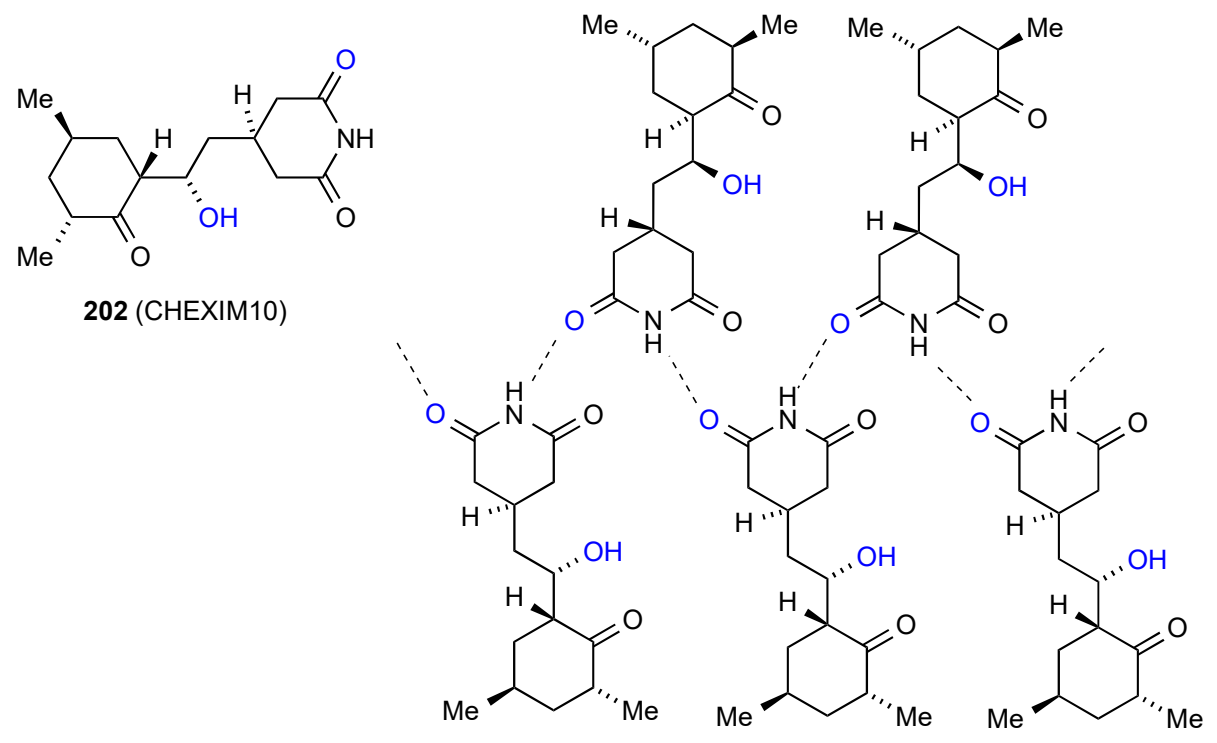

Figure 62. Structure adopted by compound 202.

\subsection{3,3-Disubstituted Glutarimides}

Of the twelve reported structures for 3,3-disubstituted glutarimides, four compounds 203 [177], 204 [178], 205 [177] and 206 [179] (Figure 63) exist as simple $R^{2}{ }_{2}(8)$ dimers of pattern A. It should be noted, however, that while $\mathbf{2 0 3}$ and 204 bond using the imide 6-CO away from the substituents, compound 205 uses the more hindered 2-CO, and for compound 206 one carbonyl of each type is involved, giving an unsymmetrical dimer. Five structures, viz. compounds 207 [160], 208 [160], 
209 [180], 210 [180] and 211 [181] display simple linear ribbon type hydrogen bonding of category $\mathbf{B}$. In the case of 207 and 208 either the CO nearer the substituents of the CO further away can be involved, giving two different structures.

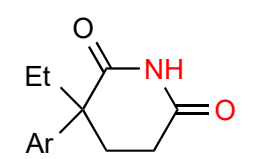

$203 \mathrm{Ar}=3-\left(\mathrm{O}_{2} \mathrm{~N}\right) \mathrm{C}_{6} \mathrm{H}_{4}$ (HOFFIR) $204 \mathrm{Ar}=4-\left(\mathrm{H}_{2} \mathrm{~N}\right) \mathrm{C}_{6} \mathrm{H}_{4}(\mathrm{JIKHIU})$<smiles>O=C1CCC(F)(N2C(=O)c3ccccc3C2=O)C(=O)N1</smiles>

207 (ZORBAL, ZOQZIQ)

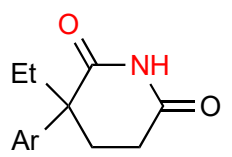

$205 \mathrm{Ar}=2,4-\left(\mathrm{O}_{2} \mathrm{~N}\right)_{2} \mathrm{C}_{6} \mathrm{H}_{3}$ (HOFFOX)<smiles>O=C1CCC(F)(N2C(=O)c3ccccc3C2=O)C(=O)N1</smiles>

208 (ZOQZIQ01) $209 \mathrm{Ar}=3-\mathrm{ClC}_{6} \mathrm{H}_{4}$ (RUQZEJ)<smiles>CCC1(Br)CCC(=O)NC1=O</smiles>

$206 \mathrm{Ar}=4-\left(\mathrm{O}_{2} \mathrm{~N}\right) \mathrm{C}_{6} \mathrm{H}_{4}$ (NOTRAP)

Figure 63. 3,3-Disubstituted glutarimides structures of pattern A or B.

Compound 212 [182] (Figure 64) exhibits a linear $C(8)$ chain of molecules where the imide NH is bonded to the remote nitrogen of the pyridine ring in pattern $\mathbf{E}$. The racemic compound 213 [160] exists as a cyclic $R^{2}{ }_{2}(14)$ dimer of category $\mathbf{D}$ where the imide $\mathrm{NH}$ is linked to the phthalimide CO.

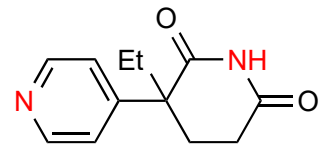

212 (SIKMII)<smiles>O=C1CCC(F)(N2C(=O)c3ccccc3C2=O)C(=O)N1</smiles>

213 (ZOQZUC)

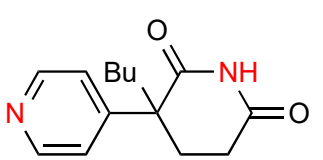

214 (SIKMOO)

Figure 64. 3,3-Disubstituted glutarimides structures of pattern D or E.

Compound 214 [182] exhibits a more complex pattern. The imide NH is again connected to the remote nitrogen of the pyridine ring in a $C(8)$ chain of pattern $\mathbf{E}$ but instead of a linear chain it forms a helix with a four-molecule repeat unit.

\subsection{3,4-Disubstituted Glutarimides}

Two structures were located for 3,4-disubstituted glutarimides of which one, compound 215 [183] (Figure 65) exists as a simple $R^{2}{ }_{2}(8)$ dimer of category $\mathbf{A}$. The second compound, 216 [183] exhibits a linear $C(4)$ ribbon pattern $\mathbf{B}$.<smiles>O=C1C[C@@H](O)[C@@H](O[PbH])[C@@H](c2ccccc2)C1</smiles>

215 (UKAXAF)<smiles>C[C@@H]1CC(=O)NC(=O)[C@@H]1Oc1ccccc1</smiles>

216 (UKAWUY)<smiles>N#C[C@H]1C[C@@H](c2ccccc2)C(=O)NC1=O</smiles>

217 (LEQSIJ)

Figure 65. 3,4- and 3,5-Disubstituted glutarimides displaying patterns $\mathbf{A}$ and $\mathbf{B}$.

\subsection{3,5-Disubstituted Glutarimides}

Two structures have been reported for 3,5-disubstituted glutarimides of which compound 217 [184] (Figure 65) exhibits a linear ribbon pattern B. Compound 218 [185] (Figure 66) exhibits a more complex 
pattern with imide $\mathrm{NH}$ to imide $\mathrm{CO} \mathrm{R}^{2}{ }_{2}(8)$ dimer units linked to each other by further head-to-tail $C(8)$ interactions of a phthalimide $\mathrm{CO}$ and the $\mathrm{OH}$ substituent on the glutarimide ring, forming a ribbon incorporating $R_{4}^{4}(24)$ units.<smiles>O=C1NC(=O)[C@H](N2C(=O)c3ccccc3C2=O)C[C@@H]1O</smiles>

218 (ENELAK)

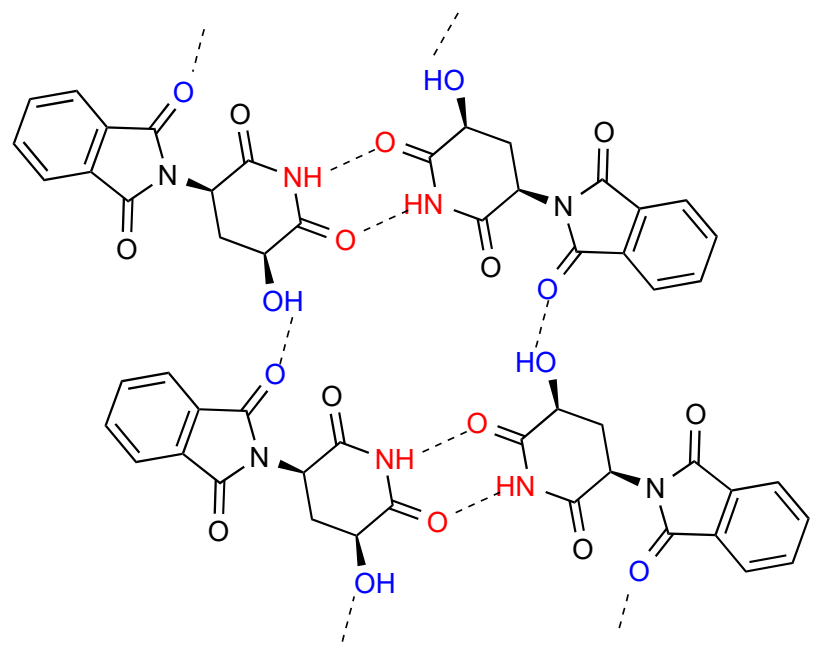

Figure 66. Structure adopted by compound 218 .

\subsection{4,4-Disubstituted Glutarimides}

Four structures have been reported for 4,4-disubstituted glutarimides. Two structures, compounds 219 [186] and 220 [187] (Figure 67) exist as simple $R^{2}{ }_{2}(8)$ dimers of Type A. Compound 221 [188] exists as a linear ribbon of pattern $\mathbf{B}$. The remaining compound 222 [189] exists as an imide NH to remote oxygen $R^{2}{ }_{2}(16)$ dimer of type $\mathbf{D}$ with the imide $\mathrm{NH}$ hydrogen bonding to one of the ester $\mathrm{CO}$ groups.<smiles>CCC1(C)CC(=O)NC(=O)C1</smiles>

219 (CIQJOC)<smiles>CC[C@@]1(c2ccccc2)CC(I)C(=O)NC1=O</smiles>

223 (EPIGAM)<smiles>CC(C)(C)OC(=O)COC(=O)N1CC(=O)CC2(CCCCC2)C1</smiles>

220 (MEBCEC)

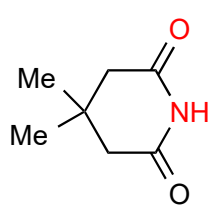

221 (AZMCHO10)<smiles>CCOC(=O)CC1(CC(=O)OCC)CC(=O)NC(=O)C1</smiles>

222 (WIYTUV)

Figure 67. 4,4-Disubstituted and trisubstituted glutarimides of patterns A, B and D.

\subsection{Trisubstituted Glutarimides}

Three structures have been published for trisubstituted glutarimides. Two of these structures: compounds 223 [190] and $224[191,192]$ (Figure 67) exist as simple imide NH to imide CO $R^{2}{ }_{2}(8)$ dimers of category A. Compound 225 [193] (Figure 68) exhibits a more complex pattern with imide NH to imide CO $R^{2}{ }_{2}(8)$ dimer units further linked to each other by a head-to tail $R^{2}{ }_{2}(16)$ interaction of phenol $\mathrm{OH}$ and ester $\mathrm{CO}$ forming a $\mathrm{C}(16)$ ribbon. 


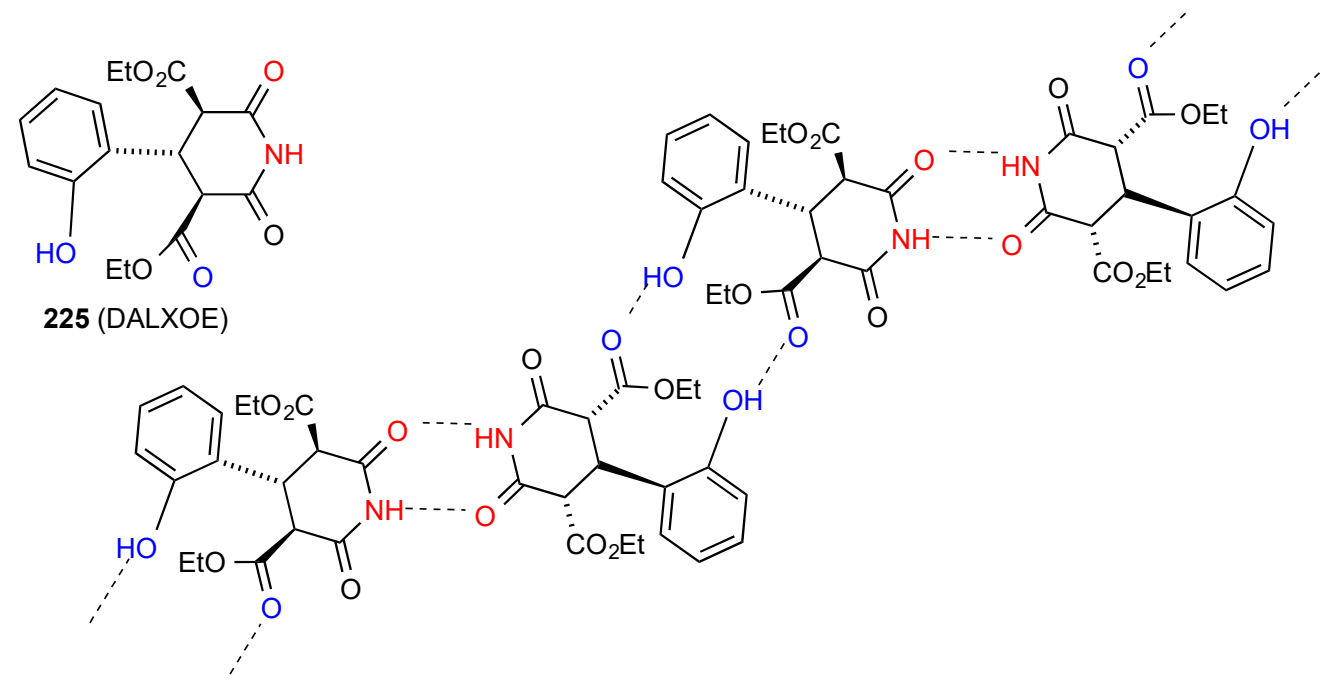

Figure 68. Structure adopted by compound 225.

\subsection{Tetra- and Pentasubstituted Glutarimides}

Seven structures have been reported for tetra- and penta-substituted glutarimides. Five structurescompounds 226 [194], 227 [195], 228 [180], 229 [196] and 230 [196] (Figure 69) exist as simple $R^{2}{ }_{2}(8)$ dimers of category A. The compounds 231 [196] and 232 [196] exist as linear C(6) chains of imide NH to remote $\mathrm{CN}$ nitrogen hydrogen bonding of pattern $\mathbf{E}$.

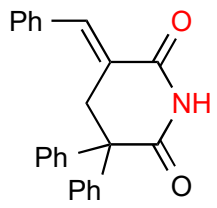

226 (NAHZAZ)

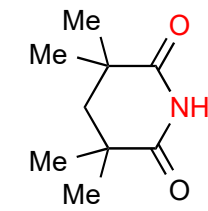

227 (RERYES)<smiles>C=C1C(=O)NC(=O)C(=C)C1c1ccccc1</smiles>

228 (RUQZOT)<smiles>CCC1(CC)C(C#N)C(=O)NC(=O)C1C#N</smiles>

229 (VINWIZ)<smiles>CC1(P)C(C#N)C(=O)NC(=O)C1C#N</smiles>

230 (VINXAS)<smiles>[R]C1(C)C(C#N)C(=O)NC(=O)C1C#N</smiles>

$231 \mathrm{R}=\mathrm{iPr}(\mathrm{VINWUL})$ $232 \mathrm{R}=\mathrm{Et}$ (VINWOF)

Figure 69. Tetra- and penta-substituted glutarimides showing patterns $\mathbf{A}$ and $\mathbf{E}$.

\subsection{Ring-Fused Glutarimides}

Four structures were reported for ring-fused glutarimides. Of these, compound 233 [197] (Figure 70) consists of equal quantities of two distinct molecules, one forming simple dimers of category $\mathbf{A}$ and the other linear ribbons of pattern $\mathbf{B}$ with these structural elements intermixed in the unit cell. Compound 234 [198] forms an imide NH to imide CO linear ribbon of pattern B. Compound 235 [199] forms simple linear $C(8)$ chains of type $\mathbf{F}$ where the imide $\mathrm{NH}$ is $\mathrm{H}$-bonded to the remote $\mathrm{CO}$ of the indolinone ring.

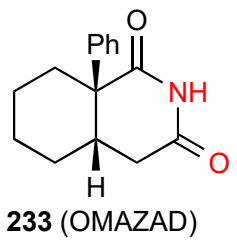<smiles>C[C@H](N[C@]12CCCC[C@H]1CC(=O)NC2=O)c1ccccc1</smiles><smiles>CCO[C@]12C(=O)NC(=O)C[C@@]1(C)[C@@H](c1ccc(C(F)(F)F)cc1)O[C@H]2c1ccccc1N</smiles>

235 (ZUBLAL)

Figure 70. Ring-fused glutarimides showing patterns A, B and F. 
The remaining structure, compound 236 [200] (Figure 71) exhibits a more complex pattern of bonding. Linear antiparallel chains facing each other are linked together by $C(8)$ imide $\mathrm{NH}$ to remote bridging oxygen interaction and this is supplemented by an imide $\mathrm{CO}$ to alcohol $\mathrm{OH}$ interaction, forming $R^{2}{ }_{2}(8)$ units.

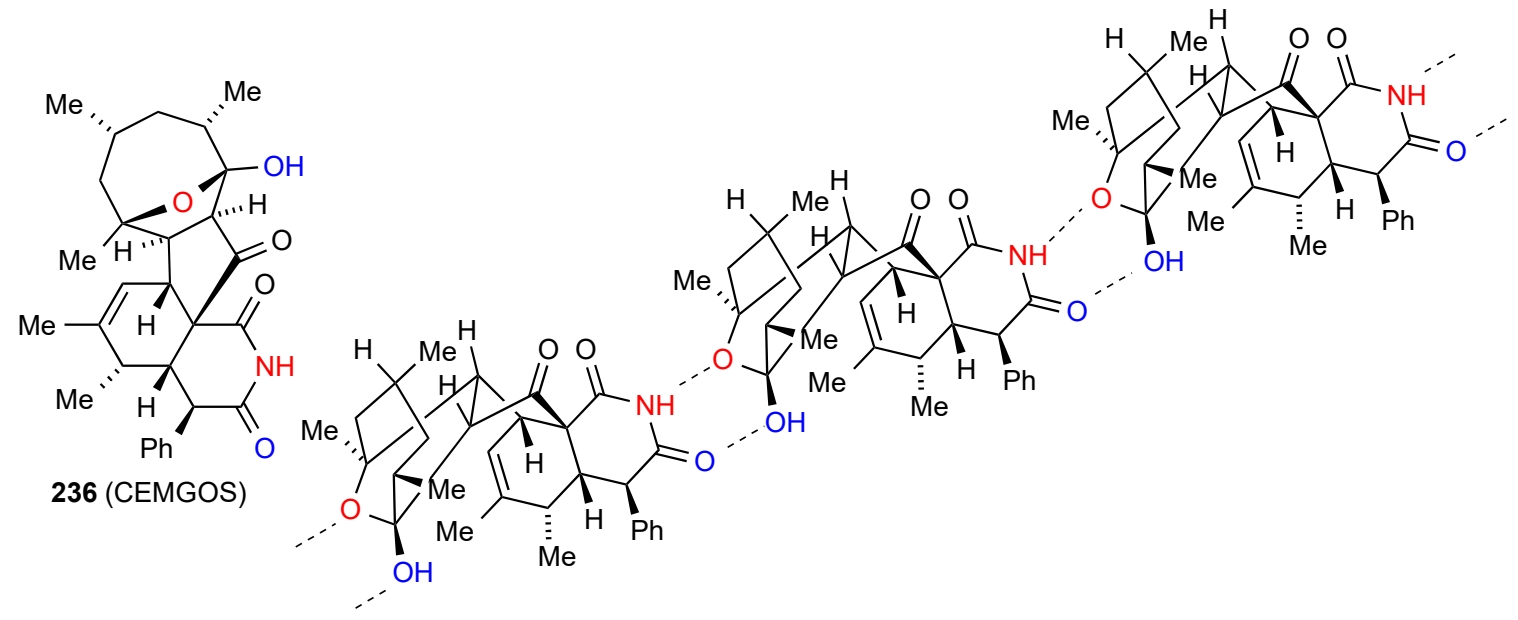

Figure 71. Structure adopted by compound 236.

\subsection{Bridged Six-Membered Ring Imides}

Of the thirty structures located for bridged six-membered ring imides, eighteen, compounds 237 [201], 238 [201], 239 [201], 240 [201], 241 [201], 242 [202], 243 [203], 244 [202], 245 [204], 246 [205], 247 [206], 248 [206], 249 [207], 250 [208], 251 [208], 252 [209], 253 [210] and 254 [211] (Figure 72) exist as simple imide $\mathrm{NH}$ to imide $\mathrm{CO}^{2}{ }_{2}(8)$ dimers of category A. Many of these are derived from the "Kemp triacid" or 1,3,5-trimethylcyclohexane-1,3,5-tricarboxylic acid.<smiles>[R]C(=O)C12CC3(C)CC(C)(C(=O)NC1=O)C(C)(C)C32C</smiles>

$237 \mathrm{R}=\mathrm{NH}\left(\mathrm{CH}_{2}\right)_{4} \mathrm{Me}(\mathrm{ADIJIG})$

$238 \mathrm{R}=\mathrm{OCH}_{2}\left(\mathrm{c}-\mathrm{C}_{6} \mathrm{H}_{11}\right)$ (ADIKAZ)

$241 \mathrm{R}=\mathrm{OCH}_{2} \mathrm{CH}_{2}\left(\mathrm{c}-\mathrm{C}_{6} \mathrm{H}_{11}\right)$ (ADIJOM)

$242 \mathrm{R}=\mathrm{O}-2$-naphthyl (LERDIV)

$243 \mathrm{R}=$ 0-6-formyl-2-naphthyl (HUGRAD)

$244 \mathrm{R}=0-3,6-(\mathrm{tBu})_{2}-2$-naphthyl (GADKIF)

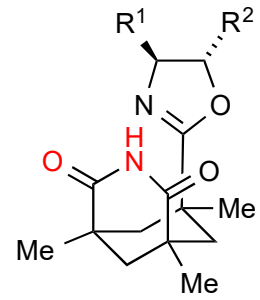

$247 \mathrm{R}^{1}=\mathrm{CH}_{2} \mathrm{Ph}, \mathrm{R}^{2}=\mathrm{H}(\mathrm{OWOLAP})$

$248 \mathrm{R}^{1}=\mathrm{tBu}, \mathrm{R}^{2}=\mathrm{H}$ (OWIWEY)

$249 \mathrm{R}^{1}=\mathrm{R}^{2}=\mathrm{Ph}(\mathrm{YUFYED})$

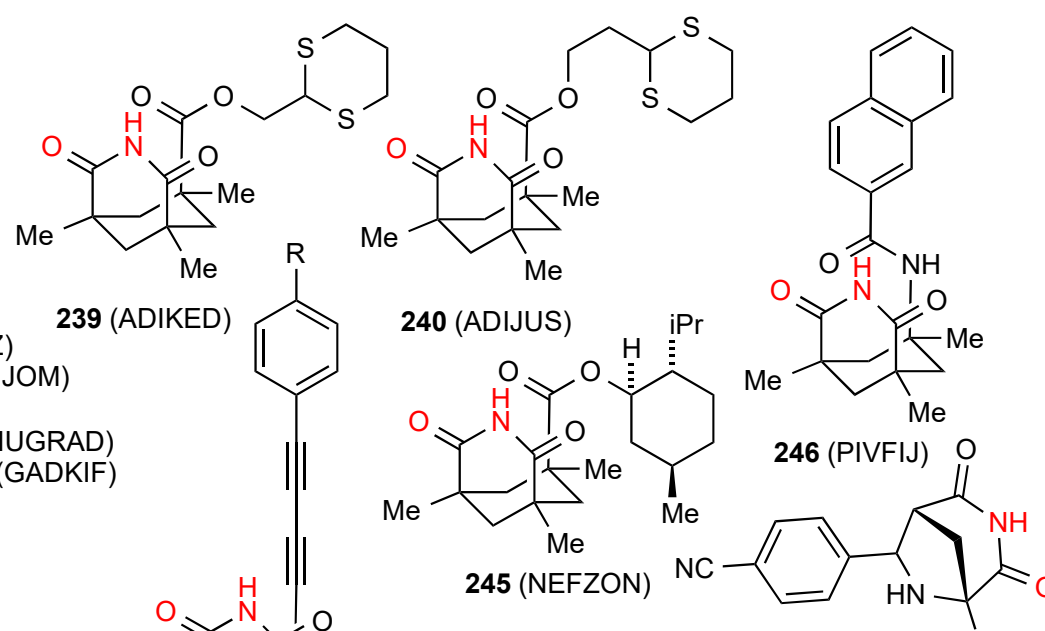

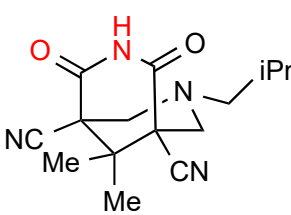

253 (PEMZOZ)<smiles>COC(=O)C1C(=O)NC(=O)C1C(C)C(=O)NC(C)(C)C(F)(F)F</smiles>

254 (BAHFIZ)

Figure 72. Bridged six-membered ring imides with pattern A dimer structures. 
Four separate structures of the compound 255 [212-215] (Figure 73) all involve imide NH hydrogen bonded to imide $\mathrm{CO}$ linear ribbon chains like category $\mathbf{B}$. The first of these contains half an equivalent of 1-methylnaphthalene in the crystal, the third involved a powder diffraction study, and the fourth structure determination under extremes of high pressure. Two structures, compounds 256 [216] and 257 [216] display pattern $\mathrm{C}$ bonding with imide $\mathrm{NH}$ forming dimers with a remote nitrogen and designations $R^{2}{ }_{2}(22)$ and $R^{2}{ }_{2}(26)$, respectively. In the latter case, there is an additional amino to imide CO interaction. The compounds 258 [217] and 259 [217] are bis imides that exhibit imide $\mathrm{NH}$ to imide $\mathrm{CO}$ doubly linked bonding pattern $\mathbf{H}$ or $\mathrm{C}^{2}{ }_{2}(6)\left[R^{2}{ }_{2}(8)\right]$. Two more extended bis imides 260 [218] and 261 [201] also exhibit pattern $\mathbf{H}$ bonding with respective designations $C^{2}{ }_{2}(14)\left[R^{2}{ }_{2}(8)\right.$ ] and $C^{2}{ }_{2}(21)\left[R^{2}{ }_{2}(8)\right]$.

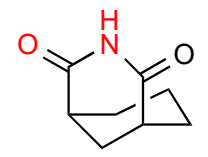

255 (MENFER, BOQQUT, BOQQUT01, BOQQUT02)

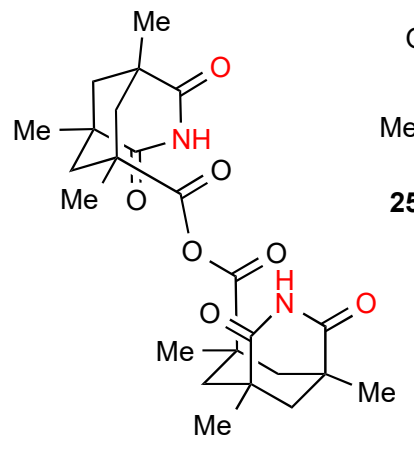
260 (ATEXIG)<smiles>CC12CC3(C)CC(C)(C1)C(C)(C2)C(=O)NC3=O</smiles>

256 (DAGWEO)<smiles>CCCn1c(C#CC2=NC3(C)CC(C)(CC2(C)C)C(=O)N3)nc2c(N)ncnc21</smiles>

257 (DAGWIS)<smiles>CC(=[18O])[18OH]</smiles><smiles>O=C1NC(=O)C2C(=O)NC(=O)C1C21CCCC1</smiles>

259 (SECDEM)

Figure 73. Bridged six-membered ring imides with pattern $\mathbf{B}, \mathbf{C}$ and $\mathbf{H}$ structures.

The two remaining structures show more complex patterns of H-bonding. Compound 262 [219] (Figure 74) exists as $R^{2}{ }_{2}$ (22) dimers with the imide $\mathrm{NH}$ of one molecule bound to the alcohol oxygen of the other molecule. This alcohol $\mathrm{OH}$ itself interacts $S(11)$ with the imide $\mathrm{CO}$ intramolecularly.<smiles>CC12CC3(C)CC(C)(CC(C)(C1)C3(C)C)N(C(=O)N1CCC[C@H]1CO)C2=O</smiles>

$262($ WADXAB)

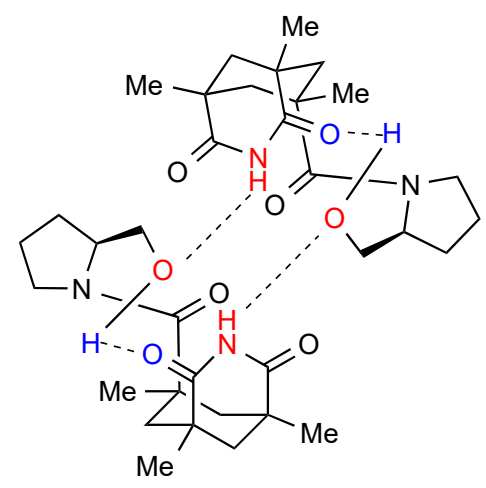<smiles>CC12CCC(C(=O)NC1=O)C2(C)C</smiles>

263 (BEYTUV)<smiles>CC1(C)CCCC1C(=O)NC(=O)C1C(=O)NC(=O)C2CCC(C)(C2(C)C)C1(C)C</smiles>

Figure 74. Structure adopted by compound 262.

Compound 263 [220] (Figure 74) also exhibits an unusual bonding pattern. The imide NH of one molecule interacts with the imide $\mathrm{CO}$ of the other molecule but the reciprocal interaction is not observed. As shown, it is the more hindered imide CO that is involved in the $D$ type bonding while the less hindered one is not. 


\subsection{Six-Membered Ring Imides with More than One Heteroatom}

Fourteen structures have been reported for six-membered ring imides with more than one heteroatom in the ring. Three structures 264 [221], 265 [222] and 266 [223] (Figure 75) exist as simple imide $\mathrm{NH}$ to imide $\mathrm{CO} R^{2}{ }_{2}(8)$ dimers of pattern A. In compound 265 [222], the imide $\mathrm{NH}$ of one molecule is hydrogen bonded to the imide $\mathrm{CO}$ of another molecule, but the reciprocal interaction does not occur, resulting in a $D$ type interaction. Compounds 267 [224] and 268 [225] exist as simple hydrogen-bonded ribbons of pattern B. Compound 269 [226] shows two crystal forms both as C(7) chains with the imide $\mathrm{NH}$ bonded to the remote $\mathrm{CO}$ of the pyrrolidinone ring in pattern $\mathbf{F}$.<smiles>O=C1NC(=O)[C@@H]2CCCCN2C1c1ccccc1</smiles>

264 (MUTKOC)<smiles>O=C1CSCC(=O)N1</smiles>

267 (GIVDUN)<smiles>O=C1NC(=O)[C@@H](c2ccccc2)N2CCCC[C@@H]12</smiles>

265 (LUDRAE)<smiles>O=C1NC(=O)[C@H](c2ccccc2)N2CCC[C@@H]12</smiles>

268 (VINFAA)<smiles>C1CCCCC1</smiles><smiles>COC1NC(=O)[C@@H](c2ccccc2)N2CCCC[C@H]12</smiles>

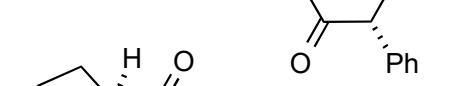<smiles>O=C1NC(=O)[C@@H](c2ccccc2)N2CCCC[C@H]12</smiles><smiles>c1ccccc1</smiles><smiles>CCOC(=O)c1c(C)c2n(c1C)CC(=O)NC2=O</smiles>

Figure 75. Six-membered ring imides with more than one heteroatom showing patterns A, B and $\mathbf{F}$.

Five structures, compounds 270 [227], 271 [228], 272 [229], 273 [229] and 274 [230] (Figure 76) are bis imides that hydrogen bond to give a doubly linked chain of pattern $\mathbf{H}$ with respective designations $C^{2}{ }_{2}(15)\left[R^{2}{ }_{2}(8)\right], C^{2}{ }_{2}(11)\left[R^{2}{ }_{2}(8)\right], C^{2}{ }_{2}(11)\left[R^{2}{ }_{2}(8)\right], C^{2}{ }_{2}(11)\left[R^{2}{ }_{2}(8)\right]$ and $C^{2}{ }_{2}(7)\left[R^{2}{ }_{2}(8)\right]$.<smiles>O=C1CN(CCCCCCN2CC(=O)NC(=O)C2)CC(=O)N1</smiles>

270 (NIFKAO)<smiles>O=C1CN([C@H]2C[C@H]2N2CC(=O)NC(=O)C2)CC(=O)N1</smiles>

272 (ICRFRC10)<smiles>[Y14]C(CN1CC(=O)NC(=O)C1)N1CC(=O)NC(=O)C1</smiles>

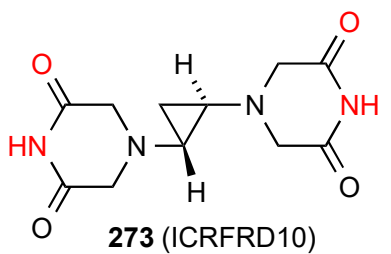<smiles></smiles>

274 (BUXPOZ)

Figure 76. Six-membered ring bis imides with more than one heteroatom showing pattern $\mathbf{H}$.

Three structures display more complex forms of hydrogen bonding. Compound 275 [228] (Figure 77), which is the racemic form of the pure enantiomer 271, forms $R^{2}{ }_{2}(16)$ dimers by interaction of one imide $\mathrm{NH}$ of each molecule with the amine nitrogen of the opposite enantiomer. These dimers are then further linked into a ribbon by $R^{2}{ }_{2}(8)$ imide $\mathrm{NH}$ to imide $\mathrm{CO}$ interactions. 


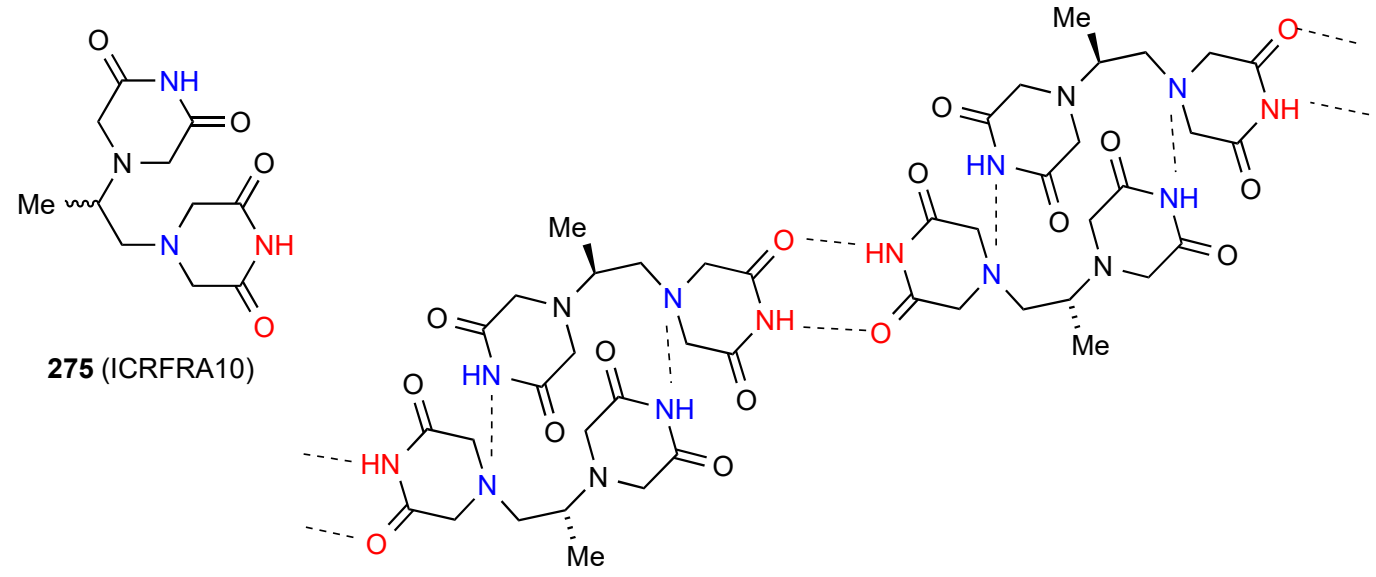

Figure 77. Structure adopted by compound 275.

Compound 276 [231,232] (Figure 78) exists in a complex pattern of hydrogen bonding. It involves formation of a two-dimensional network in which alternate molecules are arranged perpendicularly to each other and each imide NH is bonded equally between two imide CO groups. There are both $R^{2}{ }_{1}(5)$ and $R_{4}^{4}(16)$ units present.<smiles>O=C1NC(=O)C(=O)NC1=O</smiles>

276 (WAFHAO, WAFHAO01)<smiles>COC1=C(N(C)C)C(=O)N(OC)C(=O)C1=O</smiles>

Figure 78. Structure adopted by compound 276.

Compound 277 [233] (Figure 79) has two linear parallel chains of molecules linked to each other by interactions of one imide $\mathrm{CO}$ of each molecule to both the imide $\mathrm{NH}$ of one molecule in the opposite chain and an alcohol $\mathrm{OH}$ of an adjacent molecule also in the opposite chain. In this way each molecule has two donor and two acceptor interactions and is involved in two $R^{2}{ }_{2}(9)$ units, one as the four atom component and one as the five atom component and the two enantiomeric chains are strongly bound into a ribbon structure.<smiles>O=C1NC(=O)C(O)(c2ccccc2)n2cccc21</smiles>

277 (ISUTEW)

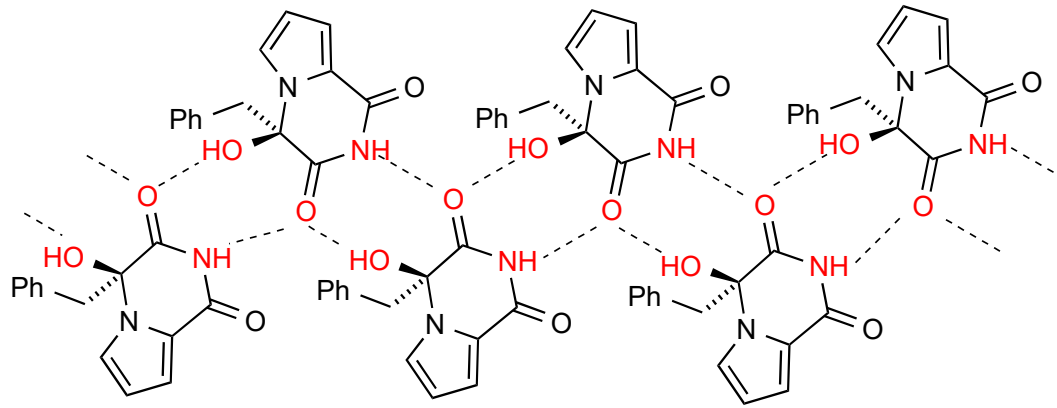

Figure 79. Structure adopted by compound 277 . 


\section{Eight- and Nine-Membered Cyclic Carboximides}

Four structures have been reported for eight- and nine-membered cyclic NH carboximides all of which, viz. 278 [234], 279 [235], 280 [235] and 281 [236] (Figure 80) exist as simple NH to CO hydrogen-bonded $R^{2}{ }_{2}(8)$ dimers of pattern $\mathbf{A}$. It is notable that between the closely similar compounds 279 and 280 the opposite imide $\mathrm{CO}$ is involved.<smiles>[Y4]C(c1ccccc1)C1C(=O)NC(=O)CCCC1I</smiles>
278 (YUCRIX)<smiles>CC/C1=C(\CC)c2ccccc2CC(=O)NC1=O</smiles>

279 (CESRID)<smiles>O=C1Cc2ccccc2/C(c2ccccc2)=C(\c2ccccc2)C(=O)N1</smiles>

280 (CESRUP)<smiles>O=C1CCc2ccccc2/C(c2ccccc2)=C(\c2ccccc2)C(=O)N1</smiles>

281 (PIFPAX)<smiles>O=C1NC(=O)[C@@]2(C/C1=C\c1ccccc1Cl)C/C(=C\c1ccccc1Cl)C(=O)c1ccccc12</smiles>

282 (NIZJOW)<smiles>O=C1NC(=O)[C@@]2(C/C1=C\c1ccccc1)C/C(=C\c1ccccc1)C(=O)c1ccccc12</smiles>

$283(\mathrm{NIZJIQ})$

Figure 80. Eight- and nine-membered ring imides and spiro imides of patterns $\mathbf{A}$ and $\mathbf{F}$.

\section{Spiro imides and Propellanes}

\subsection{Spiro Imides}

Five structures have been reported for Spiro-imides. Compound 282 [237] (Figure 80) exists as a simple hydrogen-bonded dimer of pattern A where the $\mathrm{CO}$ away from the spiro ring is involved in interaction. Compound 283 [237] in contrast, exhibits imide $\mathrm{NH}$ to remote $\mathrm{CO}$ bonding, giving a linear $C(8)$ chain of pattern $\mathbf{F}$.

Compound 284 [237] (Figure 81) involves a more complex form of bonding where dimers are formed by head-to tail $R^{2}{ }_{2}(8)$ linkage of the imide $\mathrm{NH}$ from one ring with one imide $\mathrm{CO}$ of the other. These are then further linked into a ribbon by imide $\mathrm{NH}$ to imide $\mathrm{CO} R^{2}{ }_{2}(12)$ bonding using the remaining $\mathrm{CO}$ from the imide involved the first interaction and the $\mathrm{NH}$ of the other imide.

In Compound 285 [238] (Figure 82) a complex two-dimensional network pattern is observed made up of imide $\mathrm{NH}$ to lactam $\mathrm{CO} R^{2}{ }_{2}(12)$ dimers which are arranged in a herring-bone pattern. Each dimer is then linked to four further dimers in the adjacent rows by $C(7)$ lactam $\mathrm{NH}$ to $\mathrm{CO}$ hydrogen bonding. In this case the imide carbonyls are not involved.

The compound 286 [239] (Figure 83) exists as a complex two-dimensional network in which imide $\mathrm{NH}$ to imide $\mathrm{CO} R^{2}{ }_{2}(8)$ dimer units are arranged in lines with alternating orientation and each dimer is further linked to two separate dimers in the lines on either side by a $C(8)$ interaction of the remaining $\mathrm{CO}$ of the dimer-forming imide function with the $\mathrm{NH}$ of the non-dimer-forming imide. 


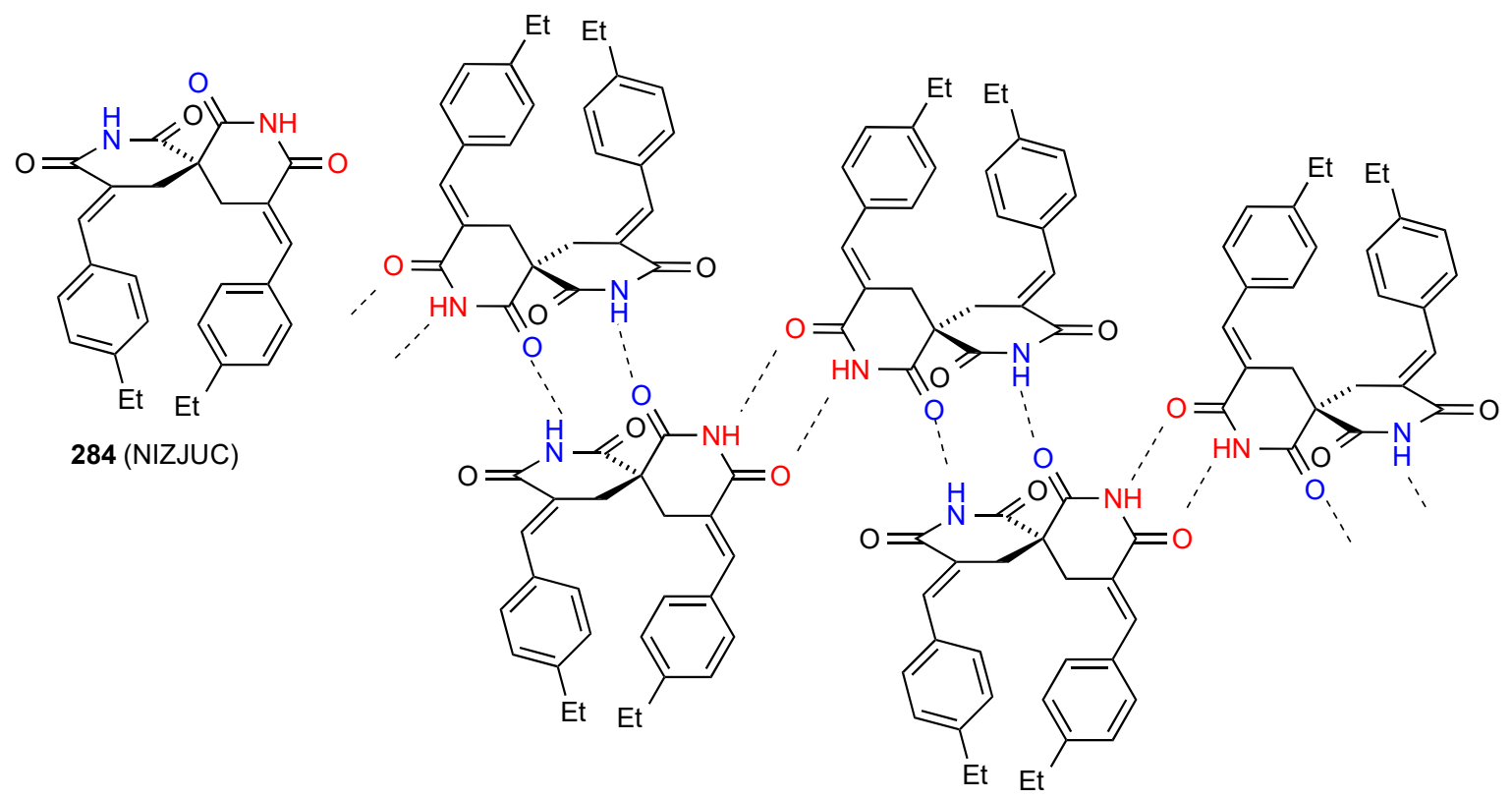

Figure 81. Structure adopted by compound 284 .

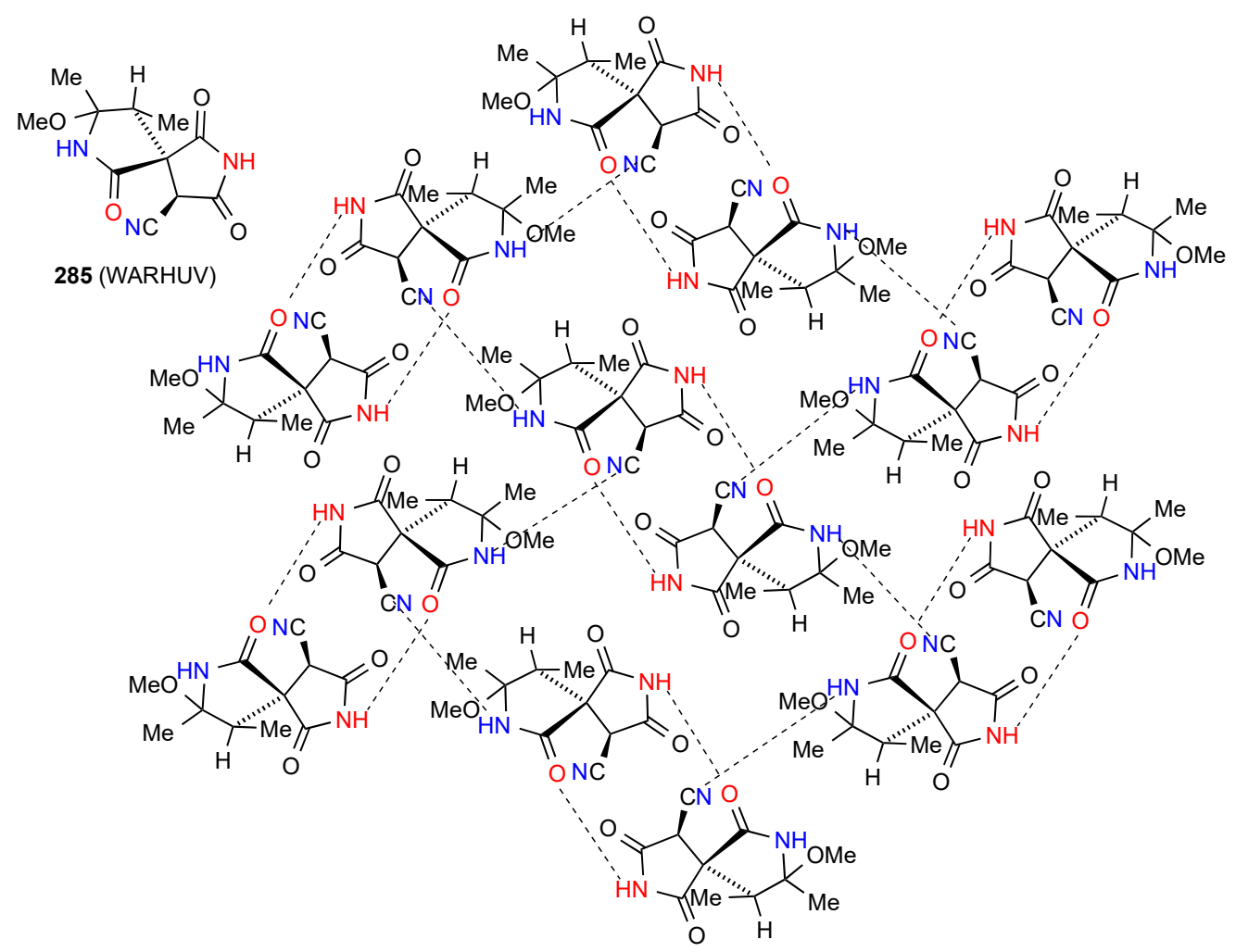

Figure 82. Structure adopted by compound 285. 


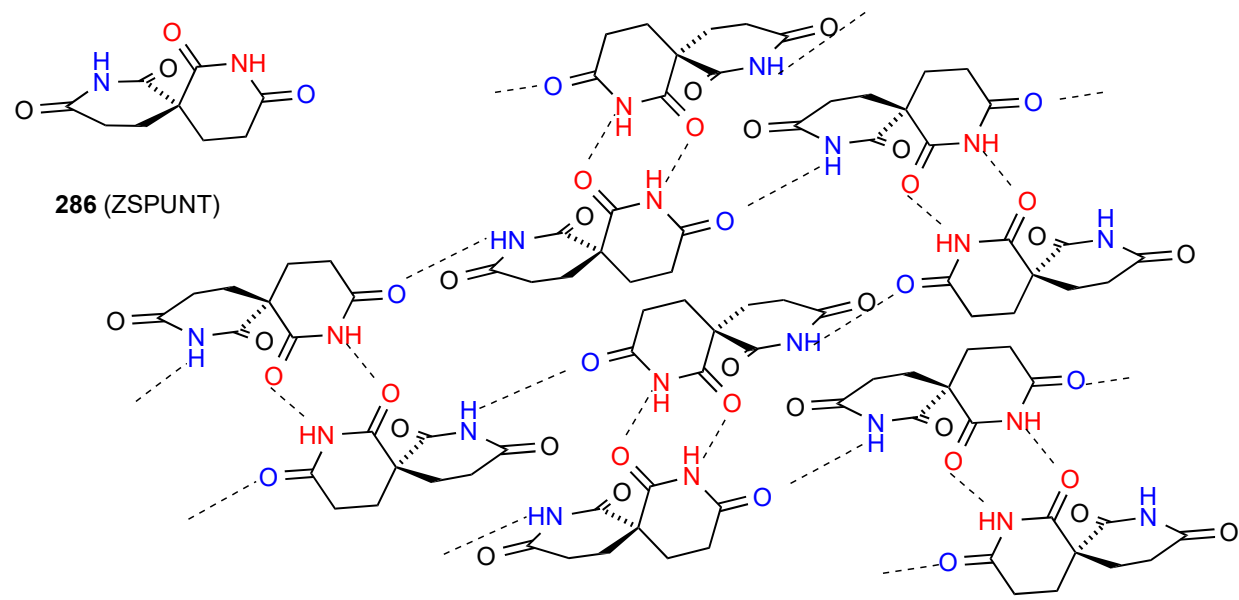

Figure 83. Structure adopted by compound 286.

\subsection{Propellanes}

Two structures have been reported for imide-containing propellanes. One of these, compound 287 [240] (Figure 84) shows no hydrogen bonding probably due to the high degree of steric hindrance. The other, compound 288 [241], exhibits linear chains with the imide NH hydrogen equally bonded to both bridging oxygens, resulting in designation $C^{2}{ }_{1}(6)\left[R^{2}{ }_{1}(6)\right]$.

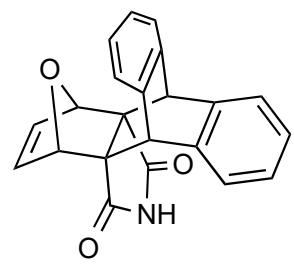

287 (IMUJEG)

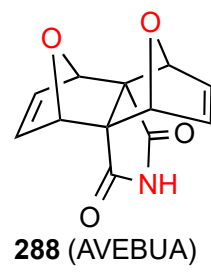

Figure 84. Structure of propellanes.

\section{Conclusions}

A large number of cyclic NH carboximides have been subject to X-ray structure determination, allowing meaningful conclusions to be drawn from analysis of the patterns observed. It is clear that imide $\mathrm{NH}$ to imide $\mathrm{CO}$ dimers are the commonest single structure observed followed by linear imide $\mathrm{NH}$ to imide $\mathrm{CO}$ ribbons, with larger substituents often favouring the dimers whereas smaller substituents are more conducive to ribbon formation. Where additional oxygen or nitrogen atoms are present in the structure, dimers and chains involving imide $\mathrm{NH}$ and these remote acceptors are also observed and there are a total of 52 compounds, mainly of this type, in which neither imide $\mathrm{CO}$ is involved in hydrogen bonding. In contrast to this situation, the imide $\mathrm{NH}$ is involved in hydrogen bonding whenever it occurs, although there are four cases (compounds 67, 161, 162 and 287) where a high degree of steric hindrance prevents any hydrogen bonding at all. The presence of further hydrogen bonding groups of various types may lead to more complex two- and three-dimensional structures and over 40 such diverse patterns are presented. There are relatively few cases where a single compound has been shown to have several different types of structure but compound 191/195/197 provides a good example, and in one case, compound 233, two separate structural types (A and B) occur together in a 1:1 ratio in the unit cell. It is also clear that for certain classes of cyclic imides, relatively few structures have so far been determined and there is ample scope for the further exploration of this area.

Author Contributions: D.K.S. located and analysed the structural data and prepared the original draft of the paper; R.A.A. conceived the study, defined the scope, resolved problems in analysis and wrote the final version. All authors have read and agreed to the published version of the manuscript. 
Funding: This research received no external funding.

Conflicts of Interest: The authors declare no conflict of interest.

\section{References}

1. Hargreaves, M.K.; Prichard, J.G.; Dave, H.R. Cyclic carboxylic monoimides. Chem. Rev. 1970, 70, 439-469. [CrossRef]

2. Luzzio, F.A. (Ed.) Imides: Medicinal, Agricultural, Synthetic Applications and Natural Products Chemistry; Elsevier: Oxford, UK, 2019.

3. Etter, M.C. Encoding and Decoding Hydrogen-Bond Patterns of Organic Compounds. Acc. Chem. Res. 1990, 23, 120-126. [CrossRef]

4. Etter, M.C.; MacDonald, J.C.; Bernstein, J. Graph-Set Analysis of Hydrogen-Bond Patterns in Organic Crystals. Acta Crystallogr. Sect. B 1990, 46, 256-262. [CrossRef] [PubMed]

5. Bernstein, J.; Davis, R.E.; Shimoni, L.; Chang, N.-L. Patterns in Hydrogen Bonding: Functionality and Graph Set Analysis in Crystals. Angew. Chem. Int. Ed. Eng. 1995, 34, 1555-1573. [CrossRef]

6. Cox, P.J.; Parker, S.F. Maleimide. Acta Crystallogr. Sect. C 1996, 52, 2578-2580. [CrossRef]

7. Light, M.E.; Vega, I.E.D.; Gale, P.A. CSD Communication; Cambridge Crystallographic Data Centre: Cambridge, UK, TEKQAB01; 2007.

8. Jiao, W.-H.; Li, J.; Liu, Q.; Xu, T.-T.; Shi, G.-H.; Yu, H.-B.; Yang, F.; Han, B.-N.; Li, M.; Lin, H.-W.; et al. Dysidinoid A, an Unusual Meroterpenoid with Anti-MRSA Activity from the South China Sea Sponge Dysidea sp. Molecules 2014, 19, 18025-18032. [CrossRef]

9. Wang, X.-B.; Zhang, Y.; Wang, J.-S.; Yao, H.-Q.; Sun, H.-B.; Kong, L.-Y. Spectroscopic characterizations, X-ray studies, and electronic circular dichroism calculations of two alkaloid triterpenoids. Struct. Chem. 2011, 22, 1241-1248. [CrossRef]

10. Pijnenborg, J.; Tinnemans, P. CSD Communication; Cambridge Crystallographic Data Centre: Cambridge, UK, 2019; XOFLEM.

11. Huang, L.; Li, Y.; Gao, D.; Du, Z.3,4-Bis(4-methoxyphenyl)-2,5-dihydro-1H-pyrrole-2,5-dione. Acta Crystallogr. Sect. E 2012, 68, o1328. [CrossRef]

12. Afanasenko, A.M.; Boyarskaya, D.V.; Boyarskaya, I.A.; Chulkova, T.G.; Grigoriev, Y.M.; Kolesnikov, I.E.; Avdontceva, M.S.; Panikorovskii, T.L.; Panin, A.I.; Vereshchagin, A.N.; et al. Structures and photophysical properties of 3,4-diaryl-1H-pyrrol-2,5-diimines and 2,3-diarylmaleimides. J. Mol. Struct. 2017, 1146, 554-561. [CrossRef]

13. Solntsev, P.V.; Dudkin, S.V.; Sabin, J.R.; Nemykin, V.N. Electronic Communications in (Z)-Bis (ferrocenyl) ethylenes with Electron-Withdrawing Substituents. Organometallics 2011, 30, 3037-3046. [CrossRef]

14. Lin, Z.; Mei, X.; Yang, E.; Li, X.; Yao, H.; Wen, G.; Chien, C.-T.; Chow, T.J.; Ling, Q. Polymorphism-dependent fluorescence of bisthienylmaleimide with different responses to mechanical crushing and grinding pressure. Cryst Eng Comm. 2014, 16, 11018-11026. [CrossRef]

15. Lin, Z.; Mei, X.; Ling, Q. CSD Communication; Cambridge Crystallographic Data Centre: Cambridge, UK, 2016; FOMVIO02.

16. Li, T.-T.; Gao, Y.-C.; Zhou, J.-X.; Huang, M.-H.; Luo, Y.-J. The bisindolylmaleimides with anti-parallel conformation by $\mathrm{N}$-dodecyl chains on indole rings: Thermal property and intensive solid-state fluorescence in single crystal. RSC Adv. 2015, 5, 84547-84552. [CrossRef]

17. Huang, M.-H.; Gao, Y.-C.; Yang, F.-L.; Luo, Y.-J. 3,4-Bis[1-(prop-2-ynyl)-1H-indol-3-yl]-1H-pyrrole-2,5-dione. Acta Crystallogr. Sect. E 2013, 69, o924-o925. [CrossRef] [PubMed]

18. Basavaiah, D.; Devendar, B.; Aravindu, K.; Veerendhar, A. A Facile One-Pot Transformation of Baylis-Hillman Adducts into Unsymmetrical Disubstituted Maleimide and Maleic Anhydride Frameworks: A Facile Synthesis of Himanimide A. Chem. Eur. J. 2010, 16, 2031-2035. [CrossRef] [PubMed]

19. Gao, Q.; Wu, X.; Li, Y.; Liu, S.; Meng, X.; Wu, A. Iodine-Promoted Sequential C ( $\mathrm{sp}^{3}$ )-H Functionalization Reactions: An Annulation Strategy for the Construction of 3-Methylthio-4-arylmaleimides. Adv. Synth. Catal. 2014, 356, 2924-2930. [CrossRef]

20. Gao, Q.; Liu, S.; Wu, X.; Wu, A. Convergent integration of three self-sorting domino sequences: Three-component direct synthesis of 3-methylthio-4-arylmaleimides from methyl ketones with acetonitrile and DMSO. Tetrahedron Lett. 2014, 55, 6403-6406. [CrossRef] 
21. Nakamura, N.; Hirakawa, A.; Gao, J.-J.; Kakuda, H.; Shiro, M.; Komatsu, Y.; Sheu, C.-C.; Hattori, M. Five New Maleic and Succinic Acid Derivatives from the Mycelium of Antrodia camphorata and Their Cytotoxic Effects on LLC Tumor Cell Line. J. Nat. Prod. 2004, 67, 46-48. [CrossRef]

22. Pilati, T.; Cozzi, F. Structures of hydro-, chloro-, and bromo-substituted maleimides and 2,6-diaminopyridines, and of some of their 1:1 heterodimers. Cryst.Eng.Comm. 2011, 13, 4549-4556. [CrossRef]

23. Bröring, M.; Brégier, F.; Kleeberg, C. 3,4-Diethyl-2,5-dihydro-1H-pyrrole-2,5-dione. Acta Crystallogr. Sect. C 2007, 63, o225-o227. [CrossRef]

24. Kaletas, B.K.; Joshi, H.C.; Van Der Zwan, G.; Fanti, M.; Zerbetto, F.; Goubitz, K.; De Cola, L.; König, B.; Williams, R.M. Asymmetric Indolylmaleimide Derivatives and Their Complexation with Zinc(II)-Cyclen. J. Phys. Chem. A 2005, 109, 9443-9455. [CrossRef]

25. Lenk, R.; Tessier, A.; Lefranc, P.; Silvestre, V.; Planchat, A.; Blot, V.; Dubreuil, D.; Lebreton, J. 1-Oxo-1H-phenalene-2,3-dicarbonitrile Heteroaromatic Scaffold: Revised Structure and Mechanistic Studies. J. Org. Chem. 2014, 79, 9754-9761. [CrossRef]

26. Basavaiah, D.; Lenin, D.V.; Veeraraghavaiah, G. Synthesis of substituted maleimide derivatives using the Baylis-Hillman adducts. Curr. Sci. 2011, 101, 888-893.

27. Schollmeyer, D.; Peifer, C.; Dannhardt, G. 4-(3-Hydroxy-4-methoxyphenyl)-3-(3,4,5-trimethoxyphenyl)-2,5dihydro-1H-pyrrole-2,5-dione. Acta Crystallogr. Sect. E 2005, 61, o604-o606. [CrossRef]

28. Martins, I.L.; Charneira, C.; Gandin, V.; Ferreira Da Silva, J.L.; Justino, G.C.; Telo, J.P.; Vieira, A.J.S.C.; Marzano, C.; Antunes, A.M.M. Selenium-Containing Chrysin and Quercetin Derivatives: Attractive Scaffolds for Cancer Therapy. J. Med. Chem. 2015, 58, 4250-4265. [CrossRef] [PubMed]

29. Kazakov, P.V.; Odinets, I.L.; Antipin, M.Y.; Petrovskii, P.V.; Kovalenko, L.V.; Struchkov, Y.T.; Mastryukova, T.A. Synthesis of 2-keto-4-phosphorylbutyric acids and their derivatives. Bull. Acad. Sci. USSR Div. Chem. Sci. 1990, 39, 1931-1937. [CrossRef]

30. Peifer, C.; Schollmeyer, D.; Dannhardt, G. 3-(1H-Indol-3-yl)-4-(3,4,5-trimethoxyphenyl)-2,5-dihydro-1H -pyrrole-2,5-dione. Acta Crystallogr. Sect. E 2005, 61, o690-o692. [CrossRef]

31. Peifer, C.; Selig, R.; Kinkel, K.; Ott, D.; Totzke, F.; Schächtele, C.; Heidenreich, R.; Röcken, M.; Schollmeyer, D.; Laufer, S. Design, Synthesis, and Biological Evaluation of Novel 3-Aryl-4-(1H-indole-3-yl)-1,5-dihydro-2H-pyrrole-2-ones as Vascular Endothelial Growth Factor Receptor (VEGF-R) Inhibitors. J. Med. Chem. 2008, 51, 3814-3824. [CrossRef]

32. Kirfel, A. 3,4,5,6-Tetrahydrophthalimide. Acta Crystallogr. Sect. B 1975, 31, 2494-2495. [CrossRef]

33. Kirfel, A.; Will, G.; Fickentscher, K. 3,6-Dithia-3,4,5,5-tetrahydrophthalimide. Acta Crystallogr. Sect. B 1975, 31, 1973-1975. [CrossRef]

34. Mahboobi, S.; Eluwa, S.; Koller, M.; Popp, A.; Schollmeyer, D. Synthesis of Pyrrolo[3' $\left.4^{\prime}: 2,3\right]$ azepino[4,5-cd]indole-8,10-diones. J. Heterocycl. Chem. 2000, 37, 1177-1185. [CrossRef]

35. Vrábel, V.; Marchalín, S.; Kozisek, J. Isopropyl 2-methyl-4-(3-nitrophenyl)-5,7-dioxo-4,5,6,7-tetrahydro-1Hpyrrolo[3,4-b]pyridine-3-carboxylate. Acta Crystallogr. Sect. E 2003, 59, o1570-o1571. [CrossRef]

36. Yang, Z.-H.; Tan, H.-R.; An, Y.-L.; Zhao, Y.-W.; Lin, H.-P.; Zhao, S.-Y. Three-Component Coupling Reactions of Maleimides, Thiols, and Amines: One-Step Construction of 3,4-Heteroatom-functionalized Maleimides by Copper-Catalyzed C (sp²)-H Thioamination. Adv. Synth. Catal. 2018, 360, 173-179. [CrossRef]

37. Mason, R. The magnetic anisotropy and electron distribution in succinimide. Acta Crystallogr. 1961, 14, 720-724. [CrossRef]

38. Yu, M.; Huang, X.; Gao, F. Pyrrolidine-2,5-dione. Acta Crystallogr. Sect. E 2012, 68, o2738. [CrossRef]

39. Argay, G.; Carstensen-Oeser, E. The Crystal Structure of 3-(N-Phenyl)aminopyrrolidine-2,5-dione. Acta Crystallogr. Sect. B 1973, 29, 1186-1190. [CrossRef]

40. Matviiuk, T.; Rodriguez, F.; Saffon, N.; Mallet-Ladeira, S.; Gorichko, M.; De Jesus Lopes Ribeiro, A.L.; Pasca, M.R.; Lherbet, C.; Voitenko, Z.; Baltas, M.; et al. Design, chemical synthesis of 3-(9H-fluoren-9-yl)pyrrolidine-2,5-dione derivatives and biological activity against enoyl-ACP reductase (InhA) and Mycobacterium tuberculosis. Eur. J. Med. Chem. 2013, 70, 37-48. [CrossRef] [PubMed]

41. Argay, G.; Kálmán, A. Crystal Structure of 3-Phenylpyrrolidine-2,5-dione. Acta Crystallogr. Sect. B 1973, 29, 636-638. [CrossRef]

42. Kwiatkowski, W.; Karolak-Wojciechowska, J. Structure of $m$-Nitrophenylsuccinimide. Acta Crystallogr. Sect. C 1992, 48, 204-206. [CrossRef] 
43. Karapetyan, A.A.; Andrianov, V.G.; Struchkov, Y.T. Alpha-(3-bromo-4-ethoxyphenyl) succinimide, $\mathrm{C}_{10} \mathrm{H}_{12} \mathrm{BrNO}_{3}$. Cryst. Struct. Commun. 1980, 9, 417-420.

44. Li, R. CSD Communication; Cambridge Crystallographic Data Centre: Cambridge, UK, 2016; IRONIO.

45. Argay, G.; Fábián, L.; Kálmán, A. On the Hydrogen Bonding of Succinimide Derivatives: Crystal Structure of 3(4-Pyridil-methyl)amino-pyrrolidine-2,5-dione. Croat. Chem. ActA 1999, 72, 551-565.

46. Al-Jalal, N.A.; Ibrahim, M.R.; Al-Awadi, N.A.; Elnagdi, M.H.; Ibrahim, Y.A. Photochemistry of Benzotriazoles: Generation of 1,3-Diradicals and Intermolecular Cycloaddition as a New Route toward Indoles and Dihydropyrrolo[3,4-b]Indoles. Molecules 2014, 19, 20695-20708. [CrossRef]

47. Dobrowolski, M.A.; Roszkowski, P.; Struga, M.; Szulczyk, D. The unexpected product of Diels-Alder reaction between "indanocyclon" and maleimide. J. Mol. Struct. 2017, 1130, 573-578. [CrossRef]

48. Toupet, L.; Biard, J.-F.; Verbist, J.-F. Dichlorolissoclimide from Lissoclinum voeltzkowi Michaelson (Urochordata): Crystal Structure and Absolute Stereochemistry. J. Nat. Prod. 1996, 59, 1203-1204. [CrossRef]

49. Yang, T.; Wang, C.-H.; Chou, G.-X.; Wu, T.; Cheng, X.-M.; Wang, Z.-T. New alkaloids from Capparis spinosa: Structure and X-ray crystallographic analysis. Food Chem. 2010, 123, 705-710. [CrossRef]

50. Takimoto, M.; Takenaka, A.; Sasada, Y. The Crystal Structure of 3-(Adenin-9-yl)-N-(2-succinimidyl) propionamide and Hydrogen Bonding Scheme of Anticonvulsant Drugs with Adenine. Bull. Chem. Soc. Jpn. 1984, 57, 3070-3073. [CrossRef]

51. Schirmer, M.-L.; Spannenberg, A.; Werner, T. Highly functionalized alkenes produced from base-free organocatalytic Wittig reactions: (E)-3-benzylidenepyrrolidine-2,5-dione, (E)-3-benzylidene-1-methyl pyrrolidine-2,5-dione and (E)-3-benzylidene-1-tert-butylpyrrolidine-2,5-dione. Acta Crystallogr. Sect. C 2016, 72, 504-508. [CrossRef] [PubMed]

52. Krivoshein, A.V.; Ordonez, C.; Khrustalev, V.N.; Timofeeva, T.V. Distinct molecular structures and hydrogen bond patterns of $\alpha, \alpha$-diethyl-substituted cyclic imide, lactam, and acetamide derivatives in the crystalline phase. J. Mol. Struct. 2016, 1121, 196-202. [CrossRef]

53. Khrustalev, V.N.; Sandhu, B.; Bentum, S.; Fonari, A.; Krivoshein, A.V.; Timofeeva, T.V. Absolute Configuration and Polymorphism of 2-Phenylbutyramide and $\alpha$-Methyl- $\alpha$-phenylsuccinimide. Cryst. Growth Des. 2014, 14, 3360-3369. [CrossRef]

54. Malamas, M.S.; Hohman, T.C.; Millen, J. Novel Spirosuccinimide Aldose Reductase Inhibitors Derived from Isoquinoline-1,3-diones: 2-[(4-Bromo-2-fluorophenyl)methyl]-6-fluorospiro[isoquinoline-4(1H), 3'-pyrrolidine]-1,2' ,3,5'(2H)-tetrone and Congeners. J. Med. Chem. 1994, 37, 2043-2058. [CrossRef]

55. Negoro, T.; Murata, M.; Ueda, S.; Fujitani, B.; Ono, Y.; Kuromiya, A.; Komiya, M.; Suzuki, K.; Matsumoto, J. Novel, Highly Potent Aldose Reductase Inhibitors: (R)-(-)-2-(4-Bromo-2-fluorobenzyl)-1,2,3,4-tetrahydropyrrolo[1,2-a]pyrazine-4-spiro-3'-pyrrolidine-1,2' 3 , $5^{\prime}$ tetrone (AS-3201) and Its Congeners. J. Med. Chem. 1998, 41, 4118-4129. [CrossRef]

56. Yang, W.-L.; Liu, Y.-Z.; Luo, S.; Yu, X.; Fossey, J.S.; Deng, W.-P. The copper-catalyzed asymmetric construction of a dispiropyrrolidine skeleton via 1,3-dipolar cycloaddition of azomethine ylides to $\alpha$-alkylidene succinimides. Chem. Commun. 2015, 51, 9212-9215. [CrossRef] [PubMed]

57. Prateeptongkum, S.; Driller, K.M.; Jackstell, R.; Spannenberg, A.; Beller, M. Efficient Synthesis of Biologically Interesting 3,4-Diaryl-Substituted Succinimides and Maleimides: Application of Iron-Catalyzed Carbonylations. Chem. Eur. J. 2010, 16, 9606-9615. [CrossRef]

58. Sheldrick, W.S. (RRS-SSR)-2-(1-Methoxyethyl)-3-methylsuccinimide. Acta Crystallogr. Sect. B 1981, 37, 299-300. [CrossRef]

59. Nieger, M.; Gutenberger, G.; Steckhan, E. CSD Communication; Cambridge Crystallographic Data Centre: Cambridge, UK, IHABUO, IHABEY; 2002.

60. Alper, H.; Mahatantila, C.P.; Einstein, F.W.B.; Willis, A.C. A novel and stereospecific imide synthesis. J. Am. Chem. SoC 1984, 106, 2708-2710. [CrossRef]

61. Alper, H.; Mahatantila, C.P.; Einstein, F.W.B.; Willis, A.C. Structure of (RS-SR)-Ethyl 2,5-Dioxo-4-phenyl-3-pyrrolidinecarboxylate, $\mathrm{C}_{13} \mathrm{H}_{13} \mathrm{NO}_{4}$. Acta Crystallogr. Sect. C 1985, 41, 548-550. [CrossRef]

62. Sato, M.; Dander, J.E.; Sato, C.; Hung, Y.-S.; Gao, S.-S.; Tang, M.-C.; Hang, L.; Winter, J.M.; Garg, N.K.; Watanabe, K.; et al. Collaborative Biosynthesis of Maleimide- and Succinimide-Containing Natural Products by Fungal Polyketide Megasynthases. J. Am. Chem. SoC 2017, 139, 5317-5320. [CrossRef] [PubMed] 
63. Hachiya, S.; Kasashima, Y.; Yagishita, F.; Mino, T.; Masu, H.; Sakamoto, M. Asymmetric transformation by dynamic crystallization of achiral succinimides. Chem. Commun. 2013, 49, 4776-4778. [CrossRef]

64. Baudour, J.L.; Messager, J.C. Structure Cristalline et Moléculaire de $1^{\prime} \alpha$-p-Chlorophenyl- $\alpha$-methyl- $\alpha^{\prime}$ -cyanosuccinimide. Acta Crystallogr. Sect. B 1971, 27, 799-806. [CrossRef]

65. Zak, Z.; Dastych, D. Crystal structure of 3,3,4,4-tetramethyl-succinimide, $\mathrm{C}_{8} \mathrm{H}_{13} \mathrm{NO}_{2}$. Zeitschrift für Kristallographie 1995, 210, 303. [CrossRef]

66. Simeth, N.A.; Altmann, L.-M.; Wössner, N.; Bauer, E.; Jung, M.; König, B. Photochromic Indolyl Fulgimides as Chromo-pharmacophores Targeting Sirtuins. J. Org. Chem. 2018, 83, 7919-7927. [CrossRef] [PubMed]

67. Zaliznaya, E.V.; Farat, O.K.; Varenichenko, S.A.; Mazepa, A.V.; Markov, V.I. Functionalization of tetra- and octahydroacridine derivatives through Michael addition. Tetrahedron Lett. 2016, 57, 3485-3487. [CrossRef]

68. Vereshchagin, A.N.; Elinson, M.N.; Dorofeeva, E.O.; Demchuk, D.V.; Bushmarinov, I.S.; Goloveshkin, A.S.; Nikishin, G.I. Chemical and electrocatalytic cascade cyclization of Guareschi imides: 'one-pot' simple and efficient way to the 2,4-dioxo-3-azabicyclo[3.1.0]hexane scaffold. Tetrahedron 2013, 69, 5234-5241. [CrossRef]

69. Polonski, T.; Milewska, M.J.; Katrusiak, A. Chiroptical properties of 1,2-cyclopropanedicarboxylic anhydrides and imides. The cyclopropane ring contribution to the Cotton effect. J. Org. Chem. 1993, 58, 3411-3415. [CrossRef]

70. Yashkanova, O.V.; Lukin, P.M.; Nasakin, O.E.; Urman, Y.G.; Khrustalev, V.N.; Nesterov, V.N.; Antipin, M.Y. 3-methyl-1-R-2-pyrazolin-5-one-4-spyrocyclopropanetetracarbonitriles. Synthesis, structure and interaction with alcohols and oximes of ketones. Zh. Org. Khim. 1997, 33, 943-950.

71. Butcher, R.J.; Hijji, Y.M.; Benjamin, E. cis-3-Azabicyclo[3.2.0]heptane-2,4-dione. Acta Crystallogr. Sect. E 2006, 62, o1266-o1268. [CrossRef]

72. Chow, Y.L.; Naguib, Y.M.A. [2 + 2] Photocycloadditions of dichloromaleimide and dichloromaleic anhydride to cyclic olefins. J. Chem. Soc. Perkin Trans. 1984, 1, 1165-1171. [CrossRef]

73. Obata, T.; Shimo, T.; Yasutake, M.; Shinmyozu, T.; Kawaminami, M.; Yoshida, R.; Somekawa, K. Remarkable interaction effects of molecular packing on site- and stereoselectivity in photocycloaddition of 2-pyrones with maleimide in the solid state. Tetrahedron 2001, 57, 1531-1541. [CrossRef]

74. Chang, Z.; Boyaud, F.; Guillot, R.; Boddaert, T.; Aitken, D.J. A Photochemical Route to 3- and 4-Hydroxy Derivatives of 2-Aminocyclobutane-1-carboxylic Acid with an all-cis Geometry. J. Org. Chem. 2018, 83, 527-534. [CrossRef]

75. Zheng, J.; Swords, W.B.; Jung, H.; Skubi, K.L.; Kidd, J.B.; Meyer, G.J.; Baik, M.-H.; Yoon, T.P. Enantioselective Intermolecular Excited-State Photoreactions Using a Chiral Ir Triplet Sensitizer: Separating Association from Energy Transfer in Asymmetric Photocatalysis. J. Am. Chem. SoC 2019, 141, 13625-13634. [CrossRef]

76. Olsen, J.A.; Banner, D.W.; Seiler, P.; Wagner, B.; Tschopp, T.; Obst-Sander, U.; Kansy, M.; Müller, K.; Diederich, F. Fluorine Interactions at the Thrombin Active Site: Protein Backbone Fragments $\mathrm{H}-\mathrm{C}_{\alpha}-\mathrm{C}=\mathrm{O}$ Comprise a Favorable C-F Environment and Interactions of C-F with Electrophiles. Chem.Bio.Chem. 2004, 5, 666-675. [CrossRef]

77. Yoshimura, A.; Nguyen, K.C.; Rohde, G.T.; Saito, A.; Yusubov, M.S.; Zhdankin, V.V. Oxidative Cycloaddition of Aldoximes with Maleimides using Catalytic Hydroxy(aryl)iodonium Species. Adv. Synth. Catal. 2016, 358, 2340-2344. [CrossRef]

78. Hong, B.-C.; Shr, Y.-J.; Wu, J.-L.; Gupta, A.K.; Lin, K.-J. Novel [6 + 2] Cycloaddition of Fulvenes with Alkenes: A Facile Synthesis of the Anislactone and Hirsutane Framework. Org. Lett. 2002, 4, 2249-2252. [CrossRef]

79. Garton, N.S.; Ward, R.W.; Copley, R.C.B. Novel products arising from bisarylmaleimide synthesis. Tetrahedron Lett. 2008, 49, 523-525. [CrossRef]

80. Dandekar, S.A.; Greenwood, S.N.; Greenwood, T.D.; Mabic, S.; Merola, J.S.; Tanko, J.M.; Wolfe, J.F. Synthesis of Succinimido[3,4-b]indane and 1,2,3,4,5,6-Hexahydro-1,5-methano-3-benzazocine-2,4-dione by Sequential Alkylation and Intramolecular Arylation of Enolates Derived from $N, N, N^{\prime} N^{\prime}$-Tetramethylbutanediamides and $N, N, N^{\prime} N^{\prime}$-Tetramethylpentanediamides. J. Org. Chem. 1999, 64, 1543-1553. [CrossRef] [PubMed]

81. Chen, L.; Sun, J.; Xie, J.; Yan, C.-G. Molecular diversity of the three-component reaction of $\alpha$-amino acids, dialkyl acetylenedicarboxylates and N-substituted maleimides. Org. Biomol. Chem. 2016, 14, 6497-6507. [CrossRef]

82. Thirumalai, P.P.; Krishnan, R.; Emanathan, G.; Doraiswamy, M. A straightforward stereoselective synthesis of cis- $10^{\prime}, 14^{\prime}$-diazaspiro[pyrrolidine-3,11'-tetracyclo[8.6.0.0 $2,7,0^{12,16}$ ] tetraene-2,5,13',15'-tetrone derivatives under solvent-free condition. J. Chem. Sci. 2015, 127, 7-12. [CrossRef] 
83. Greci, L.; Tommasi, G.; Bruni, P.; Sgarabotto, P.; Righi, L. Diastereoselectivity in 1,3-Dipolar Cycloaddition Reactions between Indolic Nitrones and Electron-Deficient Alkenes. Eur. J. Org. Chem. 2001, 2001, 3147-3153. [CrossRef]

84. Mali, P.R.; Khomane, N.B.; Sridhar, B.; Meshram, H.M.; Likhar, P.R. Synthesis of new spiro pyrrole/pyrrolizine/thiazole derivatives via $(3+2)$ cycloaddition reactions. New J. Chem. 2018, 42, 13819-13827. [CrossRef]

85. Al-Jalal, N.A.; Ibrahim, Y.A.; Al-Awadi, N.A.; Ibrahim, M.R.; Sayed, O.M. Photochemistry of 1,4-Dihydropyridine Derivatives: Diradical Formation, Delocalization and Trapping as a Route to Novel Tricyclic and Tetracyclic Nitrogen Heterocyclic Ring Systems. Molecules 2016, 21, 866. [CrossRef]

86. Zhu, C.; Luan, J.; Fang, J.; Zhao, X.; Wu, X.; Li, Y.; Luo, Y. A Rhodium-Catalyzed [3 + 2] Annulation of General Aromatic Aldimines/Ketimines and N-Substituted Maleimides. Org. Lett. 2018, 20, 5960-5963. [CrossRef]

87. Weber, M.; Frey, W.; Peters, R. Asymmetric Palladium(II)-Catalyzed Cascade Reaction Giving Quaternary Amino Succinimides by 1,4-Addition and a Nef-Type Reaction. Angew. Chem. Int. Ed. 2013, 52, 13223-13227. [CrossRef] [PubMed]

88. Beccalli, E.M.; Marchesini, A.; Pilati, T. Diels-Alder reactions of (Z)-Ethyl 3-[(1-ethoxycarbonyloxy2-methoxy)ethenyl]-2-(ethoxycarbonyloxy)indole-1-carboxylate. Synthesis of the carbazole alkaloid Carbazomycin B. Tetrahedron 1996, 52, 3029-3036. [CrossRef]

89. Walton, J.C.; Slawin, A.M.Z. CSD Communication; Cambridge Crystallographic Data Centre: Cambridge, UK, EYEREH, EYERIL; 2016.

90. Banwell, M.G.; Hockless, D.C.R.; Peters, S.C. An ABC-ring Analogue of Paclitaxel (Taxol ${ }^{\mathrm{TM}}$ ) Acta Crystallogr. Sect. C 1996, 52, 370-372. [CrossRef]

91. Ievlev, M.Y.; Ershov, O.V.; Vasil'ev, A.N.; Tafeenko, V.A.; Surazhskaya, M.D.; Nasakin, O.E. Transformations of 3,3,4-Tricyano-3,4-dihydro-2H-pyran-4-carboxamides. Synthesis of Pyrano[3,4-c]pyrrole Derivatives. Russ. J. Org. Chem. 2017, 53, 1030-1035. [CrossRef]

92. Bennett, G.D.; Bringman, L.R.; Wheeler, K.A. CSD Communication; Cambridge Crystallographic Data Centre: Cambridge, UK, UFACEL; 2009.

93. Nonn, M.; Kiss, L.; Haukka, M.; Fustero, S.; Fülöp, F. A Novel and Selective Fluoride Opening of Aziridines by XtalFluor-E. Synthesis of Fluorinated Diamino Acid Derivatives. Org. Lett. 2015, 17, 1074-1077. [CrossRef]

94. Gdaniec, M.; Nowak, E.; Milewska, M.J.; Polonski, T. (S)-trans-Cyclohexane-1,2-dicarboximide. Acta Crystallogr. Sect. C 2002, 58, o661-o662. [CrossRef] [PubMed]

95. Wang, D.-C.; Jiang, L.; Lin, W.; Pan, Y.; Sun, N.-N. Perhydrophthalimide. Acta Crystallogr. Sect. E 2007, 63, o3990. [CrossRef]

96. Benjamin, E.; Hijji, Y. The Synthesis of Unsubstituted Cyclic Imides Using Hydroxylamine under Microwave Irradiation. Molecules 2008, 13, 157-169. [CrossRef]

97. Kirfel, A. 1,2,3,6-Tetrahydrophthalimide. Acta Crystallogr. Sect. B 1976, 32, 1556-1557. [CrossRef]

98. Andersen, K.A.; Anderson, O.P. Structure of 3-Ethyl-4-oxa-1,5,6-trihydrophthalimide. Acta Crystallogr. Sect. C 1991, 47, 1991-1992. [CrossRef]

99. Kim, D.H.; Chung, Y.K. Tandem Pauson-Khand reaction and Diels-Alder reaction for access to polycycles in a one-pot reaction. Chem. Commun. 2005, 1634-1636. [CrossRef]

100. Amorese, A.; Gavuzzo, E.; Mazza, F.; Casini, G.; Ferappi, M. Structure and Conformation of 5-Methyl-1,3,4,6-tetraoxoperhydropyrrolo[3,4-c]pyridine. Acta Crystallogr. Sect. B 1982, 38, 3145-3147. [CrossRef]

101. Cowell, J.; Abualnaja, M.; Morton, S.; Linder, R.; Buckingham, F.; Waddell, P.G.; Probert, M.R.; Hall, M.J. Diastereoselective synthesis of functionalised carbazoles via a sequential Diels-Alder/ene reaction strategy. RSC Adv. 2015, 5, 16125-16152. [CrossRef]

102. Gosselin, P.; Bonfand, E.; Maignan, C.; Retoux, R. The Diels-Alder Adduct of an Enantiopure 2-Sulfinyldiene and Maleimide: (1S,2R,3S,SR)-3-Methyl-5-p-toluenesulfinylcyclohex-4-en-1,2- dicarboximide. Acta Crystallogr. Sect. C 1995, 51, 94-96. [CrossRef]

103. Gosselin, P.; Bonfand, E.; Hayes, P.; Retoux, R.; Maignan, C. Asymmetric Intermolecular Diels-Alder Reactions of Enantiopure Sulfinyl-Homo- and -Hetero-Dienes: Preliminary Results. Tetrahedron Asymmetry. 1994, 5, 781-784. [CrossRef]

104. Lobkovsky, E.; Porco, J. CSD Communication; Cambridge Crystallographic Data Centre: Cambridge, UK, 2016; UZIMIB. 
105. Zhu, J.-N.; Wang, W.-K.; Zhu, Y.; Hu, Y.-Q.; Zhao, S.-Y. Cascade Functionalization of C ( $\left.\mathrm{sp}^{3}\right)-\mathrm{Br} / \mathrm{C}\left(\mathrm{sp}^{2}\right)-\mathrm{H}$ Bonds: Access to Fused Benzo[e]isoindole-1,3,5-trione via Visible-Light-Induced Reductive Radical Relay Strategy. Org. Lett. 2019, 21, 6270-6274. [CrossRef]

106. Rivera-Chao, E.; Fañanás-Mastral, M. Synthesis of Stereodefined Borylated Dendralenes through Copper-Catalyzed Allylboration of Alkynes. Angew. Chem. Int. Ed. 2018, 57, 9945-9949. [CrossRef]

107. Wender, P.A.; Gamber, G.G.; Scanio, M.J.C. Serial $[5+2] /[4+2]$ Cycloadditions: Facile, Preparative, Multi-Component Syntheses of Polycyclic Compounds from Simple, Readily Available Starting Materials. Angew. Chem. Int. Ed. 2001, 40, 3895-3897. [CrossRef]

108. Kubota, K.; Iwamoto, H.; Yamamoto, E.; Ito, H. Silicon-Tethered Strategy for Copper(I)-Catalyzed Stereoand Regioselective Alkylboration of Alkynes. Org. Lett. 2015, 17, 620-623. [CrossRef]

109. Chakraborty, A.; Jyothi, K.; Sinha, S. Palladium-catalyzed synthesis of 2-allylindole and 2-allylbenzofuran derivatives from 2-((trimethylsilyl)ethynyl)arenes. Tetrahedron Lett. 2014, 55, 6795-6798. [CrossRef]

110. Noland, W.E.; Konkel, M.J.; Tempesta, M.S.; Cink, R.D.; Powers, D.M.; Schlemper, E.O.; Barnes, C.L. Diels-alder reactions of 3-(2-nitrovinyl) indoles: Formation of carbazoles and bridged carbazoles. J. Heterocycl. Chem. 1993, 30, 183-192. [CrossRef]

111. Banwell, M.G.; Hockless, D.C.R.; Peters, S.C. A C (10)-Oxygenated ABC-Ring Analogue of Paclitaxel (Taxol $\left.{ }^{\mathrm{TM}}\right)$. Acta Crystallogr. Sect. C 1996, 52, 1832-1834. [CrossRef]

112. von Wangelin, A.J.; Neumann, H.; Gördes, D.; Spannenberg, A.; Beller, M. Facile Three-Component Coupling Procedure for the Synthesis of Substituted Tetrahydroisoindole-1,3-diones from $\alpha, \beta$-Unsaturated Aldehydes. Org. Lett. 2001, 3, 2895-2898. [CrossRef]

113. Struga, M.; Krawiecka, M.; Kossakowski, J.; Stefanska, J.; Miroslaw, B.; Koziol, A.E. Synthesis and Structural Characterisation of Derivatives of Tricyclo[5.2.1.0 2,6 $]$ dec-8-ene-3,5-dione with an Expected Antimicrobial Activity. J. Chin. Chem. SoC 2008, 55, 1258-1265. [CrossRef]

114. Steel, P.J.; Brimble, M.A.; Hopkins, B.; Rennison, D. Two stereoisomers of the rat toxicant norbormide. Acta Crystallogr. Sect. C 2004, 60, o374-o376. [CrossRef]

115. Hong, B.-C.; Shr, Y.-J.; Liao, J.-H. Unprecedented Microwave Effects on the Cycloaddition of Fulvenes. A New Approach to the Construction of Polycyclic Ring Systems. Org. Lett. 2002, 4, 663-666. [CrossRef] [PubMed]

116. Chandrasekhar, S. CSD Communication; Cambridge Crystallographic Data Centre: Cambridge, UK, 2006 ; IJIUH.

117. Chandrasekhar, S.; Gorla, S.K. CSD Communication; Cambridge Crystallographic Data Centre: Cambridge, UK, 2006; PESVOZ.

118. Miluykov, V.; Bezkishko, I.; Zagidullin, A.; Sinyashin, O.; Lönnecke, P.; Hey-Hawkins, E. Cycloaddition Reactions of 1-Alkyl-3,4,5-triphenyl-1,2-diphosphacyclopenta-2,4-dienes. Eur. J. Org. Chem. 2009, 1269-1274. [CrossRef]

119. Struga, M.; Miroslaw, B.; Pakosinska-Parys, M.; Drzewiecka, A.; Borowski, P.; Kossakowski, J.; Koziol, A.E. Synthesis, characterization and supramolecular synthons in crystals of new derivatives of 10-oxa-4-azatricyclo[5.2.1.02,6]dec-8-ene-3,5-dione. J. Mol. Struct. 2010, 965, 23-30. [CrossRef]

120. Bielenica, A.; Struga, M.; Miroslaw, B.; Koziol, A.E.; Kossakowski, J.; Sanna, G.; La Colla, P.; Giliberti, G. Synthesis and biological evaluation of $N$-substituted polycyclic imides derivatives. Acta Pol. Pharm. Drug Res. 2013, 70, 809-822.

121. Mitzi, D.B.; Afzali, A. Diels-Alder Adduct of Pentacene and Maleimide: Crystal Growth and the Influence of Solvent Molecules on Structure and Hydrogen Bonding. Cryst. Growth Des. 2007, 7, 691-697. [CrossRef]

122. Kossakowski, J.; Bielenica, A.; Miroslaw, B.; Koziol, A.E.; Dybala, I.; Struga, M. 4-Azatricyclo[5.2.2.0 2,6] undecane-3,5,8-triones as Potential Pharmacological Agents. Molecules 2008, 13, 1570-1583. [CrossRef]

123. Nishikawa, T.; Kakiya, H.; Shinokubo, H.; Oshima, K. Novel [2 + $2+2]$ Annulation of 1,6-Diynes Mediated by Methallylchromate or Methallylmagnesium Chloride under $\mathrm{CrCl}_{3}$ Catalysis. J. Am. Chem. SoC 2001, 123, 4629-4630. [CrossRef] [PubMed]

124. Kuran, B.; Kossakowski, J.; Cieslak, M.; Kazmierczak-Baranska, J.; Krolewska, K.; Cyrański, M.K.; Stepien, D.K.; Krawiecka, M. Synthesis and biological activity of novel series of heterocyclic compounds containing succinimide moiety. Heterocycl. Commun. 2013, 19, 287-296. [CrossRef]

125. Pakosinska-Parys, M.; Kossakowski, J.; Miroslaw, B.; Koziol, A.E.; Stefanska, J. Synthesis and pharmacological activity of 1,8,11,11-tetramethyl-4-azatricyclo[5.2.2.0 $\left.0^{2,6}\right]$ undec-8-ene-3,5-dione derivatives. Acta Pol. Pharm. Drug Res. 2013, 70, 505-515. 
126. Miroslaw, B.; Koziol, A.E.; Bielenica, A.; Dziuba, K.; Struga, M. Substituent effect on supramolecular motifs in series of succinimide polycyclic keto derivatives-Spectroscopic, theoretical and crystallographic studies. J. Mol. Struct. 2014, 1074, 695-702. [CrossRef]

127. Gong, Y.; Zhou, Y.; Qin, J.; Li, J.; Cao, R. Synthesis, crystal structure and photoluminescence of 2,6-dimethylanthracene and its pseudo-triptycene derivatives. J. Mol. Struct. 2010, 963, 76-81. [CrossRef]

128. Nasakin, O.E.; Lyshchikov, A.N.; Lukin, P.M.; Konovalikhin, S.V.; Bulai, A.K.; Terent'ev, P.B.; Zolotoi, A.B.; Pleshkova, A.P. Stereoselective synthesis of tricyclic derivatives of 2-amino-1-pyrrolin-5-one dimethyl acetals. Russ. Chem. Bull. 1993, 42, 491-496. [CrossRef]

129. Vásquez, R.; Vetterlein, C.; Trujillo, A.; Escobar, C.A.; Araya-Fuentes, E. Syntesis and crystalline structure of the exo-3,6-dimethyl-3,6-epoxi-1,2,3,6-tetrahydrophtalimide and its $N$-bromodecyl analog: Two thermally labile Diels-Alder adducts. J. Chil. Chem. SoC 2014, 59, 2474-2476. [CrossRef]

130. Zeng, Y. CSD Communication; Cambridge Crystallographic Data Centre: Cambridge, UK, LADCEB; 2016.

131. Zeng, Y.-B.; Liu, X.-L.; Zhang, Y.; Li, C.-J.; Zhang, D.-M.; Peng, Y.-Z.; Zhou, X.; Du, H.-F.; Tan, C.-B.; Zhang, Y.-Y.; et al. Cantharimide and Its Derivatives from the Blister Beetle Mylabris phalerata Palla. J. Nat. Prod. 2016, 79, 2032-2038. [CrossRef]

132. Chandrasekhar, S.; Gorla, S.K. Novel cis-trans enantiomeric conglomerates: Triage and absolute configurations via anomalous $\mathrm{X}$-ray scattering. A photochemical second order asymmetric transformation. Tetrahedron Asymmetry. 2006, 17, 2247-2251. [CrossRef]

133. Gidron, O.; Shimon, L.J.W.; Leitus, G.; Bendikov, M. Reactivity of Long Conjugated Systems: Selectivity of Diels-Alder Cycloaddition in Oligofurans. Org. Lett. 2012, 14, 502-505. [CrossRef] [PubMed]

134. Hammer, N.; Erickson, J.D.; Lauridsen, V.H.; Jakobsen, J.B.; Hansen, B.K.; Jacobsen, K.M.; Poulsen, T.B.; Jørgensen, K.A. Catalytic Asymmetric [4 + 2]-Cycloadditions Using Tropolones: Developments, Scope, Transformations, and Bioactivity. Angew. Chem. Int. Ed. 2018, 57, 13216-13220. [CrossRef]

135. Kossakowski, J.; Pakosinska-Parys, M.; Struga, M.; Dybala, I.; Koziol, A.E.; La Colla, P.; Marongiu, L.E.; Ibba, C.; Collu, D.; Loddo, R. Synthesis and Evaluation of in Vitro Biological Activity of 4-Substituted Arylpiperazine Derivatives of 1,7,8,9-Tetrachloro-10,10-dimethoxy-4-azatricyclo[5.2.1.0 2,6]dec-8-ene-3,5dione. Molecules 2009, 14, 5189-5202. [CrossRef]

136. Rousseau, G.; Robert, F.; Schenk, K.; Landais, Y. Rearrangement of Spirocyclic Oxindoles with Lithium Amide Bases. Org. Lett. 2008, 10, 4441-4444. [CrossRef] [PubMed]

137. Rousseau, G.; Robert, F.; Landais, Y. Functionalization and Rearrangement of Spirocyclohexadienyl Oxindoles: Experimental and Theoretical Investigations Chem. Eur. J. 2009, 15, 11160-11173. [CrossRef] [PubMed]

138. Maeba, I.; Usami, F.; Ishikawa, T.; Furukawa, H.; Ishida, T.; Inoue, M. Diels-Alder adducts of glycosylfurans with maleimide. Application of x-ray diffraction and C.D. spectra to the determination of their stereochemistry. Carbohydr. Res. 1985, 141, 1-12. [CrossRef]

139. Bennett, G.D.; Spengler, A.O.; Wheeler, K.A. CSD Communication; Cambridge Crystallographic Data Centre: Cambridge, UK, BAMSUG; 2016.

140. Zhang, X.; Han, L.; Gao, Y.; Shi, J.; Suo, Q. Photolysis and cycloaddition reactivity of diferrocenyl substituted cyclopentadienone. Chem. Res. Chin. Univ. 2016, 32, 775-780. [CrossRef]

141. Kucherov, F.A.; Galkin, K.I.; Gordee, E.G.; Ananikov, V.P. Efficient route for the construction of polycyclic systems from bioderived HMF. Green Chem. 2017, 19, 4858-4864. [CrossRef]

142. Butler, D.N.; Shang, M.; Warrener, R.N. A molecular 'hamburger': Bonded benzene in a bun. Chem. Commun. 2001, 159-160. [CrossRef]

143. Konovalova, V.V.; Shklyaev, Y.V.; Slepukhin, P.A.; Maslivets, A.N. Direct heterocyclization of [3,4-dihydroisoquinolin-1(2H)-ylidene]acetamides with aroylketenes. Crystal and molecular structure of (Z)-3-(4a-methyl-1,3,4,4a,5,10b-hexahydrophenanthridin-6(2H)-ylidene)-4-phenylpyridine-2,6(1H,3H)-dione. Arkivoc 2013, 4, 15-20. [CrossRef]

144. Würthner, F.; Yao, S.; Schilling, J.; Wortmann, R.; Redi-Abshiro, M.; Mecher, E.; Gallego-Gomez, F.; Meerholz, K. ATOP Dyes. Optimization of a Multifunctional Merocyanine Chromophore for High Refractive Index Modulation in Photorefractive Materials. J. Am. Chem. SoC 2001, 123, 2810-2824. [CrossRef]

145. Oshega, J.S.; Paponov, B.V.; Omelchenko, I.V.; Shishkin, O.V. One-pot three-component synthesis of 3-cyano-4-methyl-2,6-dioxopyridine amino enones. Mendeleev Commun. 2015, 25, 133-134. [CrossRef]

146. Bonamico, M.; Coppola, F.; Giacomello, G.; Vaciago, A.; Zambonelli, L. Molecular structure of $\alpha$-bromo- $\gamma$-ethyl- $\gamma$-phenylglutaconimide. Gazz. Chim. Ital. 1962, 92, 1319-1333. 
147. Poschenrieder, H.; Stachel, H.-D.; Wiesend, B.; Polborn, K. New azabenzoquinones by ring-expansion reactions. J. Heterocycl. Chem. 2003, 40, 61-69. [CrossRef]

148. Wiegand, C.; Herdtweck, E.; Bach, T. Enantioselectivity in visible light-induced, singlet oxygen [2+4] cycloaddition reactions (type II photooxygenations) of 2-pyridones. Chem. Commun. 2012, 48, 10195-10197. [CrossRef]

149. Tasker, N.R.; Rastelli, E.J.; Blanco, I.K.; Burnett, J.C.; Sharlow, E.R.; Lazo, J.S.; Wipf, P. In-flow photooxygenation of aminothienopyridinones generates iminopyridinedione PTP4A3 phosphatase inhibitors. Org. Biomol. Chem. 2019, 17, 2448-2466. [CrossRef] [PubMed]

150. Salamoun, J.M.; McQueeney, K.E.; Patil, K.; Geib, S.J.; Sharlow, E.R.; Lazo, J.S.; Wipf, P. Photooxygenation of an amino-thienopyridone yields a more potent PTP4A3 inhibitor. Org. Biomol. Chem. 2016, 14, 6398-6402. [CrossRef] [PubMed]

151. McDonald, E.; Horton, P.N.; Hursthouse, M.B. 3-Amino-2-methyl-2,7-dihydropyrazolo[4,3-c]pyridine-4,6dione, Univ. Southampt. Cryst. Struct. Rep. Arch. 2007, 290. [CrossRef]

152. Banks, R.E.; Jondi, W.J.; Pritchard, R.G.; Tipping, A.E. 5-Fluoro-8,8-dimethyl-7-oxa-3,9-diazabicyclo[4.3.0] nona-5,9-diene-2,4-dione $\left(\mathrm{C}_{8} \mathrm{H}_{7} \mathrm{FN}_{2} \mathrm{O}_{3}\right)$ : A Novel Product from Pyrolysis of $\mathrm{N}$-Isopropylidene-Otetrafluoro-4-pyridylhydroxylamine in Glass. Acta Crystallogr. Sect. C 1995, 51, 515-517. [CrossRef]

153. Ukrainets, I.V.; Bereznyakova, N.L.; Parshikov, V.A.; Shishkina, S.V. 4-hydroxy-2-quinolones. 114. Synthesis and structure of 6-R-5-hydroxy-2,4-dioxo-2,3,4,6-tetrahydrobenzo[c][2,7]naphthyridine-1- carbonitriles. Chem. Heterocycl. Compd. 2007, 43, 608-616. [CrossRef]

154. Row, T.N.G.; Venkatesan, K.; Sharma, V.K.; Kasturi, T.R. Crystal and Molecular Structure of 8a-Bromo-1,2,3,5,6,7,8,8a-octahydro-1,3-dioxoisoquinoline-4-carbonitrile. J. Chem. Soc. Perkin Trans. 2 1975, 14, 1597-1600. [CrossRef]

155. Smyth, L.A.; Matthews, T.P.; Horton, P.N.; Hursthouse, M.B.; Collins, I. Divergent cyclisations of 2-(5-amino-4-carbamoyl-1H-pyrazol-3-yl)acetic acids with formyl and acetyl electrophiles. Tetrahedron 2007, 63, 9627-9634. [CrossRef]

156. Mahiout, Z.; Lomberget, T.; Goncalves, S.; Barret, R. Solvent-dependent oxidations of 5- and 6-azaindoles to trioxopyrrolopyridines and functionalised azaindoles. Org. Biomol. Chem. 2008, 6, 1364-1376. [CrossRef] [PubMed]

157. Petersen, C.S. The Crystal Structure of Glutarimide. Acta Chem. Scand. 1971, 25, 379. [CrossRef]

158. Petersen, C.S. The Crystal Structure of $N$-( $\alpha$-Glutarimido)-4-bromophthalimide. Acta Chem. Scand. 1969, 23, 2389-2402. [CrossRef]

159. Kampmann, S.S.; Skelton, B.W.; Yeoh, G.C.; Abraham, L.J.; Lengkeek, N.A.; Stubbs, K.A.; Heath, C.H.; Stewart, S.G. G. The synthesis and fluorescence profile of novel thalidomide analogues. Tetrahedron 2015, 71, 8140-8149. [CrossRef]

160. Maeno, M.; Tokunaga, E.; Yamamoto, T.; Suzuki, T.; Ogino, Y.; Ito, E.; Shiro, M.; Asahi, T.; Shibata, N. Self-disproportionation of enantiomers of thalidomide and its fluorinated analogue via gravity-driven achiral chromatography: Mechanistic rationale and implications. Chem. Sci. 2015, 6, 1043-1048. [CrossRef]

161. Allen, F.H.; Trotter, J. Crystal and molecular structure of thalidomide, $N$-( $\alpha$-glutarimido)-phthalimide. J. Chem. Soc. B 1971, 1073-1079. [CrossRef]

162. Suzuki, T.; Tanaka, M.; Shiro, M.; Shibata, N.; Osaka, T.; Asahi, T. Evaluation of stability difference between asymmetric homochiral dimer in (S)-thalidomide crystal and symmetric heterochiral dimer in (RS)-thalidomide crystal. Phase Transitions. 2010, 83, 223-234. [CrossRef]

163. Yeung, S.Y.; Kampmann, S.; Stubbs, K.A.; Skelton, B.W.; Kaskow, B.J.; Abraham, L.J.; Stewart, S.G. Novel thalidomide analogues with potent NFkB and TNF expression inhibition. Med. Chem. Comm. 2011, 2, 1073-1078. [CrossRef]

164. Skelton, B.W.; Stewart, S.G.; Kampmann, S.S. CSD Communication; Cambridge Crystallographic Data Centre: Cambridge, UK, 2018; MICXUU.

165. Zhang, Y.-M.; Zhang, S.-H.; Luo, B.-S. Crystal and molecular structure of 3-( $p$-toluenesulfonamido)-2,6piperidinedione $\left(\mathrm{C}_{12} \mathrm{H}_{14} \mathrm{O}_{4} \mathrm{~N}_{2} \mathrm{~S}\right)$. Jiegou HuaxuE 1990, 9, 296-300.

166. Walz, S.; Weis, S.; Franz, M.; Rominger, F.; Trapp, O. Investigation of the enantiomerization barriers of the phthalimidone derivatives EM12 and lenalidomide by dynamic electrokinetic chromatography. Electrophoresis 2015, 36, 796-804. [CrossRef] [PubMed] 
167. Ravikumar, K.; Sridhar, B. Lenalidomide, an anti neoplastic drug, and its hemihydrate. Acta Crystallogr. Sect. C 2009, 65, o502-o505. [CrossRef]

168. Hijji, Y.; Benjamin, E.; Jasinski, J.P.; Butcher, R.J. Crystal structure of the thalidomide analog $\left(3 \mathrm{a} R^{*}, 7 \mathrm{a} S^{*}\right)-2-(2,6$-dioxopiperidin-3-yl)hexahydro-1H-isoindole-1,3(2H)-dione. Acta Crystallogr. Sect. E 2018, 74, 1595-1598. [CrossRef] [PubMed]

169. Hijji, Y.M.; Benjamin, E.; Benjamin, E.; Butcher, R.J.; Jasinski, J.P. 3-(2,6-Dioxopiperidin-3-yl)-3azabicyclo[3.2.0]heptane-2,4-dione. Acta Crystallogr. Sect. E 2009, 65, o394-o395. [CrossRef] [PubMed]

170. Wanner, M.J.; Koomen, G.-J. Stereoselective Synthesis of the Indole Alkaloids Nitrarine, Nitramidine, and Isomers. A Biomimetic Approach. J. Org. Chem. 1994, 59, 7479-7484. [CrossRef]

171. Chennuru, R.; Muthudoss, P.; Voguri, R.S.; Ramakrishnan, S.; Vishweshwar, P.; Babu, R.R.C.; Mahapatra, S. Iso-Structurality Induced Solid Phase Transformations: A Case Study with Lenalidomide. Cryst. Growth Des. 2017, 17, 612-628. [CrossRef]

172. Onan, K.D.; Rao, H.S.P.; Parry, R.J. Structure of the Aromatic Glutarimide Antibiotic Actiphenol, 4-[2-(2-Hydroxy-3,5-dimethylphenyl)-2-oxoethyl]-2,6-piperidinedione, $\mathrm{C}_{15} \mathrm{H}_{17} \mathrm{NO}_{4}$. Acta Crystallogr. Sect. C 1985, 41, 428-431. [CrossRef]

173. Powell, R.G.; Smith, C.R., Jr.; Weisleder, D.; Matsumoto, G.K.; Clardy, J.; Kozlowski, J. Sesbanimide, a potent antitumor substance from Sesbania drummondii seed. J. Am. Chem. SoC 1983, 105, 3739-3741. [CrossRef]

174. Sonoda, T.; Kobayashi, K.; Ubukata, M.; Osada, H.; Isono, K. Bsolute configuration of epiderstatin, a new glutarimide antibiotic produced by Streptomyces pulveraceus. J. Antibiot. 1992, 45, 1963-1965. [CrossRef]

175. Guo, H.-F.; Li, Y.-H.; Yi, H.; Zhang, T.; Wang, S.-Q.; Tao, P.-Z.; Li, Z.-R. Synthesis, structures and anti-HBV activities of derivatives of the glutarimide antibiotic cycloheximide. J. Antibiot. 2009, 62, 639-642. [CrossRef] [PubMed]

176. Sayers, J.; Schindler, D.; Sundaralingam, M. Simultaneous occurrence of a chair and a boat conformation in crystalline cycloheximide. J. Am. Chem. SoC 1977, 99, 3848-3850. [CrossRef]

177. Danilovski, A.; Vinkovic, M.; Filic, D. Nitro derivatives of glutethimide. Acta Crystallogr. Sect. C 1999, 55, 1300-1304. [CrossRef]

178. Van Roey, P.; Bullion, K.A.; Osawa, Y.; Braun, D.G. Structure of ( \pm )-Aminoglutethimide. Acta Crystallogr. Sect. C 1991, 47, 829-832. [CrossRef] [PubMed]

179. Achmatowicz, O.; Malinowska, I.; Szechner, B.; Maurin, J.K. Resolution of 4-cyano-4-(4-nitrophenyl)hexanoic acid: Synthesis of $(R)$ and (S)-3-(4-aminophenyl)-3-ethylpiperidine-2,6-dione (aminoglutethimide). Tetrahedron 1997, 53, 7917-7928. [CrossRef]

180. Basavaiah, D.; Lenin, D.V.; Devendar, B. A simple protocol for the synthesis of a piperidine-2,6-dione framework from Baylis-Hillman adducts. Tetrahedron Lett. 2009, 50, 3538-3542. [CrossRef]

181. Koch, M.H.J.; Dideberg, O. The crystal and molecular structure of 1-benzyl-4-(2,6-dioxo-3-phenyl-3piperidyl)piperidine, $\mathrm{C}_{23} \mathrm{H}_{26} \mathrm{~N}_{2} \mathrm{O}_{2}$ (benzetimide). Acta Crystallogr. Sect. B 1973, 29, 369-371. [CrossRef]

182. Laughton, C.A.; McKenna, R.; Neidle, S.; Jarman, M.; McCague, R.; Rowlands, M.G. Crystallographic and molecular modeling studies on 3-ethyl-3-(4-pyridyl)piperidine-2,6-dione and its butyl analog, inhibitors of mammalian aromatase. Comparison with natural substrates: Prediction of enantioselectivity for $\mathrm{N}$-alkyl derivatives. J. Med. Chem. 1990, 33, 2673-2679. [CrossRef]

183. Takaya, H.; Yoshida, K.; Isozaki, K.; Terai, H.; Murahashi, S.-I. Transition-Metal-Based Lewis Acid and Base Ambiphilic Catalysts of Iridium Hydride Complexes: Multicomponent Synthesis of Glutarimides. Angew. Chem. Int. Ed. 2003, 42, 3302-3304. [CrossRef]

184. Bienko, D.C.; Michalska, D.; Borrell, J.I.; Teixidó, J.; Matallana, J.L.; Alvarez-Larena, A.; Piniella, J.F. Structure of 2-cyano-4-phenyl-glutarimide studied by X-ray diffraction, vibrational spectroscopy and ab initio methods. J. Mol. Struct. 1998, 471, 49-56. [CrossRef]

185. Doi, M.; Ijiri, Y.; Akagi, M.; Uenishi, M.; Urata, H. Crystal structure of 5'-hydroxythalidomide in vivo metabolite of thalidomide in humans. Anal. Sci. X-ray Struct. Anal. OnlinE 2003, 19, x51-x52. [CrossRef]

186. Tutughamiarso, M.; Bolte, M. 4-Ethyl-4-methyl piperidine-2,6-dione. Acta Crystallogr. Sect. E 2007, 63, o4743. [CrossRef]

187. Hu, X.-R.; Xu, W.-M.; Gu, J.-M. 3-Azaspiro[5.5]undecane-2,4-dione. Acta Crystallogr. Sect. E 2006, 62, o264-o265. [CrossRef]

188. Bocelli, G.; Grenier-Loustalot, M.F. The Structure of 4,4-Dimethylazacyclohexane-2,6-dione (4,4-Dimethyl-2,6-piperidinedione). Acta Crystallogr. Sect. B 1981, 37, 1302-1304. [CrossRef] 
189. Pascal, R.A., Jr.; Carter, M.L.; Ho, D.M. CSD Communication; Cambridge Crystallographic Data Centre: Cambridge, UK, 2014; WIYTUV.

190. Bonamico, M.; Coppola, F.; Giacomello, G. Crystal structure of $\alpha$-phenyl- $\alpha$-ethyl- $\alpha^{\prime}$-iodoglutarimide. Gazz. Chim. Ital. 1961, 91, 193-203.

191. Raj, R.; Mehra, V.; Singh, P.; Kumar, V.; Bhargava, G.; Mahajan, M.P.; Handa, S.; Slaughter, L.M. $\beta$-Lactam-Synthon-Interceded, Facile, One-Pot, Diastereoselective Synthesis of Functionalized Tetra/Octahydroisoquinolone Derivatives. Eur. J. Org. Chem. 2011, 2697-2704. [CrossRef]

192. Singh, P.; Raj, R.; Bhargava, G.; Hendricks, D.T.; Handa, S.; Slaughter, L.M.; Kumar, V. $\beta$-Lactam synthon-interceded diastereoselective synthesis of functionalized octahydroindole-based molecular scaffolds and their in vitro cytotoxic evaluation. Eur. J. Med. Chem. 2012, 58, 513-518. [CrossRef] [PubMed]

193. Raev, L.D.; Frey, W.; Ivanov, I.C. Coumarin-enaminoester Adducts: Structure Corrections (X-ray) and Some Novel Transformations. Synthesis of Annulated Tricyclic 2-Pyridones. Synlett 2004, 35, 1584-1588. [CrossRef]

194. Basavaiah, D.; Lenin, D.V. A Facile Synthesis of Substituted Indenones and Piperidine-2,6-diones from the Baylis-Hillman Acetates. Eur. J. Org. Chem. 2010, 5650-5658. [CrossRef]

195. Maurin, J.K.; Czarnocki, Z.; Paluchowska, B.; Winnicka-Maurin, M. Conformation-Related Reaction Efficiency of Glutarimides with Phenyllithium. Structures of 3,3,5,5-Tetramethylglutarimide and 2-Hydroxy-2-phenyl-3,3,5,5-tetramethyl-6-piperidone. X-ray and Theoretical Study. Acta Crystallogr. Sect. B 1997, 53, 719-725. [CrossRef]

196. Nguyen, B.; Chernous, K.; Endlar, D.; Odell, B.; Piacenti, M.; Brown, J.M.; Dorofeev, A.S.; Burasov, A.V. Alkyl Radical Generation in Water under Ambient Conditions-A New Look at the Guareschi Reaction of 1897. Angew. Chem. Int. Ed. 2007, 46, 7655-7658. [CrossRef] [PubMed]

197. Luxenburger, A. The synthesis of carnosol derivatives. Tetrahedron 2003, 59, 3297-3305. [CrossRef]

198. Bisel, P.; Fondekar, K.P.; Volk, F.-J.; Frahm, A.W. Stereoselective synthesis of (1R,2S)- and (1S,2R)-1-amino-cis-3-azabicyclo[4.4.0]decan-2,4-dione hydrochlorides: Bicyclic glutamic acid derivatives. Tetrahedron 2004, 60, 10541-10545. [CrossRef]

199. Wu, J.-S.; Zhang, X.; Zhang, Y.-L.; Xie, J.-W. Synthesis and antifungal activities of novel polyheterocyclic spirooxindole derivatives. Org. Biomol. Chem. 2015, 13, 4967-4975. [CrossRef] [PubMed]

200. Xu, G.-B.; Li, L.-M.; Yang, T.; Zhang, G.-L.; Li, G.-Y. Chaetoconvosins A and B, Alkaloids with New Skeleton from Fungus Chaetomium. convolutum. Org. Lett. 2012, 14, 6052-6055. [CrossRef]

201. Castellano, R.K.; Gramlich, V.; Diederich, F. Rebek Imides and Their Adenine Complexes: Preferences for Hoogsteen Binding in the Solid State and in Solution. Chem. Eur. J. 2002, 8, 118-129. [CrossRef]

202. Rebek, J., Jr.; Williams, K.; Parris, K.; Ballester, P.; Jeong, K.-S. Molecular Recognition: Stacking Interactions Influence Watson-Crick vs. Hoogsteen Base-Pairing in a Model for Adenine Receptors. Angew. Chem. Int. Ed. 1987, 26, 1244-1245. [CrossRef]

203. Xu, S.-G.; Wang, C.-H.; Liu, J.-S.; Liu, X.-G.; Li, L. 6-Formyl-2-naphthyl cis-1,5,7-trimethyl-2,4-dioxo3-azabicyclo[3.3.1]nonane-7-carboxylate. Acta Crystallogr. Sect. E 2010, 66, o245. [CrossRef]

204. Bach, T.; Bergmann, H.; Grosch, B.; Harms, K.; Herdtweck, E. Synthesis of Enantiomerically Pure 1,5,7-Trimethyl-3-azabicyclo[3.3.1]nonan-2-ones as Chiral Host Compounds for Enantioselective Photochemical Reactions in Solution. Synthesis 2001, 1395-1405. [CrossRef]

205. Huc, I.; Rebek, J., Jr. Molecular recognition of adenine: Role of geometry, electronic effects and rotational restrictions. Tetrahedron Lett. 1994, 35, 1035-1038. [CrossRef]

206. Pažout, R.; Maixner, J.; Pecháček, J.; Vilhanová, B.; Kačer, P. Synthesis and characterization of two new chiral Kemp's acid derivatives: Structures fixed by a peculiar system of $\mathrm{N}-\mathrm{H} \cdots \mathrm{O}, \mathrm{C}-\mathrm{H} \cdots \mathrm{O}$ and $\mathrm{C}-\mathrm{H} \cdots \mathrm{N}$ hydrogen bonds. Zeitschrift für Kristallographie-Crystalline Materials 2016, 231, 531-539. [CrossRef]

207. Yanagisawa, A.; Kikuchi, T.; Watanabe, T.; Kuribayashi, T.; Yamamoto, H. Catalytic enantioselective protonation of simple enolate with chiral imide. Synlett 1995, 372-374. [CrossRef]

208. Riwar, L.-J.; Trapp, N.; Kuhn, B.; Diederich, F. Substituent Effects in Parallel-Displaced $\pi-\pi$ Stacking Interactions: Distance Matters. Angew. Chem. Int. Ed. 2017, 56, 11252-11257. [CrossRef] [PubMed]

209. Kudryavtsev, K.V.; Churakov, A.V. 4-[(1RS,5RS,7SR)-5-Methyl-2,4-dioxo-3,6-diazabicyclo[3.2.1] octan-7-yl]benzonitrile. Acta Crystallogr. Sect. E 2012, 68, o1718. [CrossRef] [PubMed]

210. Khrustaleva, A.N.; Frolov, K.A.; Dotsenko, V.V.; Aksenov, N.A.; Aksenova, I.V.; Krivokolysko, S.G. Synthesis of new functionalized 3,7-diazabicyclo[3.3.1]nonanes by aminomethylation of the Guareschi imides. Tetrahedron Lett. 2017, 58, 4663-4666. [CrossRef] 
211. Hörlein, U.; Schröder, T.; Born, L. Über unsymmetrisch N-substituierte Bispidine (3,7-Diazabicyclo[3.3.1]nonane), III. Liebigs Ann. Chem. 1981, 1699-1704. [CrossRef]

212. Hulme, A.T.; Fernandes, P.; Florence, A.; Johnston, A.; Shankland, K. Powder study of 3-azabicyclo[3.3.1]nonane-2,4-dione 1-methylnaphthalene hemisolvate. Acta Crystallogr. Sect. E 2006, 62, o3752-o3754. [CrossRef]

213. Howie, R.A.; Skakle, J.M.S. 3-Azabicyclo[3.3.1]nonane-2,4-dione: CSP2001 structure prediction test case No. 1. Acta Crystallogr. Sect. E 2001, 57, o822-0824. [CrossRef]

214. Hulme, A.T.; Fernandes, P.; Florence, A.; Johnston, A.; Shankland, K. Powder study of 3-azabicyclo[3.3.1]nonane-2,4-dione form 2. Acta Crystallogr. Sect. E 2006, 62, o3046-o3048. [CrossRef]

215. Wood, P.A.; Haynes, D.A.; Lennie, A.R.; Motherwell, W.D.S.; Parsons, S.; Pidcock, E.; Warren, J.E. The Anisotropic Compression of the Crystal Structure of 3-Aza-bicyclo(3.3.1)nonane-2,4-dione to 7.1 GPa. Cryst. Growth Des. 2008, 8, 549-558. [CrossRef]

216. Faraoni, R.; Blanzat, M.; Kubicek, S.; Braun, C.; Schweizer, W.B.; Gramlich, V.; Diederich, F. New Rebek imide-type receptors for adenine featuring acetylene-linked $\pi$-stacking platforms. Org. Biomol. Chem. 2004, 2, 1962-1964. [CrossRef] [PubMed]

217. Vatsadze, S.Z.; Manaenkova, M.A.; Vasilev, E.V.; Venskovsky, N.U.; Khrustalev, V.N. Crystal structures and supra molecular features of 9,9-dimethyl-3,7-diazabicyclo[3.3.1] nonane-2,4,6,8-tetraone, 3,7-diazaspiro[bicyclo[3.3.1]nonane-9,1'-cyclopentane]-2,4,6,8-tetraone and 9-methyl-9-phenyl-3,7-diazabicyclo[3.3.1]nonane-2,4,6,8-tetraone dimethylformamide monosolvate. Acta Crystallogr. Sect. E 2017, 73, 1097-1101. [CrossRef]

218. Faraoni, R.; Castellano, R.K.; Gramlich, V.; Diederich, F. H-Bonded complexes of adenine with Rebek imide receptors are stabilised by cation $-\pi$ interactions and destabilised by stacking with perfluoroaromatics. Chem. Commun. 2004, 370-371. [CrossRef]

219. Odo, Y.; Shimo, T.; Kawaminami, M.; Somekawa, K. Crystal structure of imide-amide between Kemp's acid and L-Prolinol. Anal. Sci. X-ray Struct. Anal. Online 2004, 20, x119-x120. [CrossRef]

220. Huang, W.; Qian, H.; Li, Y.; Chu, Z.; Gou, S. Crystal structure of D-(+)-camphoric imide. Anal. Sci. X-ray Struct. Anal. Online 2004, 20, x75-x76. [CrossRef]

221. Tkaczyk, M.; Dawidowski, M.; Herold, F.; Wolska, I.; Wawer, I. ${ }^{13}$ C CPMAS NMR, XRD and DFT study of selected 2,6-diketopiperazines. J. Mol. Struct. 2010, 975, 78-84. [CrossRef]

222. Dawidowski, M.; Herold, F.; Wilczek, M.; Kleps, J.; Wolska, I.; Turlo, J.; Chodkowski, A.; Widomski, P.; Bielejewska, A. The synthesis and conformational analysis of optical isomers of 4-phenyl-perhydropyrido[1,2-a]pyrazine-1,3-dione: An example of 'solid state-frozen' dynamics in nitrogen-bridged bicyclic 2,6-diketopiperazines. Tetrahedron Asymmetry 2009, 20, 1759-1766. [CrossRef]

223. Voievudskyi, M.; Astakhina, V.; Kryshchyk, O.; Petuhova, O.; Shyshkina, S. Synthesis and reactivity of novel pyrrolo[1,2-a]pyrazine derivatives. Monatshefte für Chemie-Chem. Mon. 2016, 147, 783-789. [CrossRef]

224. Aitken, R.A.; Slawin, A.M.Z.; Yeh, P.-P. Tetrahydro-1,4-thiazine-3,5-dione. Molbank 2018, 2018 , M1036. [CrossRef]

225. Herold, F.; Dawidowski, M.; Wolska, I.; Chodkowski, A.; Kleps, J.; Turlo, J.; Zimniak, A. The synthesis of new diastereomers of $(4 S, 8 \mathrm{a} S)$ - and (4R,8aS)-4-phenyl-perhydropyrrole[1,2-a]pyrazine-1,3-dione. Tetrahedron Asymmetry 2007, 18, 2091-2098. [CrossRef]

226. Roth, E.; Altman, J.; Kapon, M.; Ben-Ishai, D. Amidoalkylation of aromatics with glyoxylic acid- $\gamma$-lactam adducts: 2-pyrrolidinone, pyroglutamic acid amide and ester. Tetrahedron 1995, 51, 801-810. [CrossRef]

227. Liu, Q.; Zhang, S.-W.; Shao, M.-C. Anticancer Agents. III. 4,4'-(Hexane-1,6-diyl) bis (piperazine-2,6-dione). Acta Crystallogr. Sect. C 1998, 54, 439-440. [CrossRef] [PubMed]

228. Hempel, A.; Camerman, N.; Camerman, A. Stereochemistry of the antitumor agent 4,4'-(1,2-Propanediyl) bis(4-piperazine-2,6-dione): Crystal and molecular structures of the racemate (ICRF-159) and a soluble enantiomer (ICRF-187). J. Am. Chem. SoC. 1982, 104, 3453-3456. [CrossRef]

229. Hempel, A.; Camerman, N.; Camerman, A. Stereochemistry of conformationally restricted analogues of the antitumor agent ICRF-159: Crystal and molecular structures of cis- and trans-cyclopropylbis (dioxopiperazine). J. Am. Chem. SoC. 1982, 104, 3456-3458. [CrossRef]

230. Hempel, A.; Camerman, N.; Camerman, A. Stereochemistry of conformationally restricted analogues of the antitumor agent ICRF-159. 2. Structures of antimetastatically active and inactive isomers of a tricyclic analog. J. Am. Chem. SoC. 1983, 105, 2350-2354. [CrossRef] 
231. Jia, J.-J.; Meng, X.-J.; Liang, S.-Z.; Zhang, S.-H.; Jiang, Y.-M. Piperazine-2,3,5,6-tetraone, Acta Crystallogr. Sect. E 2010, 66, o3315. [CrossRef]

232. Kovalchkova, O.V.; Do, N.D.; Stash, A.I.; Strashnova, S.B.; Zaitsev, B.E. Crystal and molecular structures of selected oxidative nitration products of aminopyrazine and 2-amino-3-hydroxypyridine. Crystallogr. Rep. 2014, 59, 60-65. [CrossRef]

233. Tian, H.; Ermolenko, L.; Gabant, M.; Vergne, C.; Moriou, C.; Retailleau, P.; Al-Mourabit, A. Pyrrole-Assisted and Easy Oxidation of Cyclic $\alpha$-Amino Acid-Derived Diketopiperazines under Mild Conditions. Adv. Synth. Catal. 2011, 353, 1525-1533. [CrossRef]

234. Hernandez, R.; Melian, D.; Prange, T.; Suarez, E. Radical $\beta$-fragmentation of bicyclo[3.3.0] carbinolamides: Synthesis of five- and eight-membered cyclic imides. Heterocycles 1995, 41, 439-454. [CrossRef]

235. Frutos-Pedreño, R.; González-Herrero, P.; Vicente, J.; Jones, P.G. Sequential Insertion of Alkynes and CO or Isocyanides into the Pd-C Bond of Cyclopalladated Phenylacetamides. Synthesis of Eight-Membered Palladacycles, Benzo[d]azocine-2,4(1H,3H)-diones, and Highly Functionalized Acrylonitrile and Acrylamide Derivatives. Organometallics 2012, 31, 3361-3372. [CrossRef]

236. Frutos-Pedreño, R.; González-Herrero, P.; Vicente, J.; Jones, P.G. Synthesis and Reactivity of Ortho-Palladated 3-Phenylpropanamides. Insertion of $\mathrm{CO}, \mathrm{XyNC}$, and Alkynes into the Pd-C Bond. Synthesis of Seven- and Nine-Membered Palladacycles and Benzazepine- and Benzazonine-Based Heterocycles. Organometallics 2013, 32, 1892-1904. [CrossRef]

237. Basavaiah, D.; Reddy, R.J. Simple and facile synthesis of tetralone-spiro-glutarimides and spiro-bisglutarimides from Baylis-Hillman acetates. Org. Biomol. Chem. 2008, 6, 1034-1039. [CrossRef] [PubMed]

238. Fedoseev, S.V.; Lipin, K.V.; Ershov, O.V.; Belikov, M.Y.; Tafeenko, V.A. Synthesis of 9-Alkyl-8-methoxy-8-methyl-1,3,6-trioxo-2,7-diazaspiro[4.4]nonane-4-carbonitriles. Russ. J. Org. Chem. 2016, 52, 1606-1609. [CrossRef]

239. Tamura, H.; Ogawa, K.; Nakatsu, K. 2,7-Diazaspiro[5.5]undecane-1,3,6,8-tetraone, $\mathrm{C}_{9} \mathrm{H}_{10} \mathrm{~N}_{2} \mathrm{O}_{4}$. Cryst. Struct. Commun. 1975, 4, 661-665.

240. Margetic, D.; Butler, D.N.; Warrener, R.N.; Murata, Y. Domino Diels-Alder reactions of N-methoxyethyl-7-oxa-norbornadiene-2,3-dicarboximide: An elusive, highly reactive dienophile. Tetrahedron 2011, 67, 1580-1588. [CrossRef]

241. Murphy, R.B.; Norman, R.E.; White, J.M.; Perkins, M.V.; Johnston, M.R. Tetra-porphyrin molecular tweezers: Two binding sites linked via a polycyclic scaffold and rotating phenyl diimide core. Org. Biomol. Chem. 2016, 14, 8707-8720. [CrossRef] 